\title{
JAVANESE WAYANG KULIT IN THE TIMES OF COMEDY: CLOWN SCENES, INNOVATION, AND THE PERFORMANCE'S BEING IN THE PRESENT WORLD' PART ONE
}

Nggih, kados kartun, mangke oyak-oyakan. Bagong 'punoyak Wrekudara, lajeng mlebet sawah, lajeng kepepet ndhelik ketingal bokongipun, Wrekudara nyedhak, iki ngentut, mlayu! Ha ha ha ha ha! Takut! Wong senopati kok wedi karo entut! Ha ha ha ha ha! (Yes, like a cartoon, there would be a chase. Bagong [a fat clownservant] is chased by Wrekudara [a name of the powerful warrior Prince Bima, one of the Pandawa brothers], then they enter a ricefield, now [Bagong] is cornered, he hides himself and only his behind is visible, Wrekudara gets close, this one [Bagong] farts, [Wrekudara] runs away! Ha ha ha ha ha! Scared! A general is scared by a fart! Ha ha ha ha ha!)

-Ki Dhalang Djoko Edan (The Honorable Puppeteer Crazy Djoko), describing a scene in wayang (from an interview with the author)

\footnotetext{
${ }^{1}$ This essay is based on Chapter Eight of my dissertation. It was written just before the changes that began to take place in Indonesia in 1998. A Postscript at the end of Part Two will address the way that wayang $k u l i t$ and its function has been affected by the economic and political changes. I would like to thank Ki Naryocarito, Stan O'Connor, Marty Hatch, and Jim Siegel. Field research was funded in part by a fellowship from the Social Science Research Council.
} 
Ha ha ha ha ha! Wayange edan kabeh!

("Ha ha ha ha ha! The puppets are all insane!")

- A spectator at a wayang performance

Dasar kini memang zaman dagelan.

("For indeed these are the times of comedy.")

- Raden Mas Sajid

\section{Introductory Notes}

Opinions about the recent developments in the performances of the Javanese shadow puppet theater (wayang kulit) vary greatly. Innovative performances of wayang are able to attract thousands of spectators and are regularly broadcast on television and the radio. Many people see innovation and wayang's popularity today as positive developments. Many other people, including many performers (even some of those who incorporate radical innovation into their performances), claim that wayang is "falling apart" or "broken" (bubrah, rusak), that it prostitutes itself as it seeks popularity, and only serves the tastes of the present. Not only does wayang have an identity or character that is, in a complex way, its own-a way of being itself and holding together as it is transformed-but-and this too is part of what wayang iswayang has its own dilemmas, uncertainties, doubts, and misgivings about the way it is and it should be. It changes as it clings to its past and faces the future (this may be what Stanley O'Connor means by "the quest for the present"), ${ }^{2}$ it looks and faces now in one direction, now in another, and its face constantly changes expression in response to its changing inner state and in response to what it is facing and with what it is being faced, at the same time that it tries to keep up appearances ("in this world in which appearance becomes reality and we must be what we seem"). ${ }^{3}$ In short, it is alive, it vibrates with life, it has both life's inconstancy and its persistence. This "quest for the present," this willingness to put itself at risk and constantly revise itself and its relation to the world-which often means sacrificing some of its principles-is not only an endeavor to survive. Wayang's "quest for the present," with the many tensions and conflicts that some interpret as signs of its vitality where others see signs of dissolution, is also one of the sources of the energy to be found in wayang performances, which enables wayang to attract thousands of spectators and mesmerize them or leave them perplexed, to make them reflect or unite them in laughter.

This essay contemplates the way that contemporary Central Javanese wayang kulit performance is in the present world or in the present "times," and it does so primarily by focusing on certain aspects of the performance that, at first sight, may appear not to be directly related to one another: the clown scenes ("comic interludes" is another term often used in English writings), innovation and newness in wayang, and the way

2 Stanley J. O'Connor, "Memory and Discovery in Southeast Asian Art," Asian Art E Culture, 8,1 (Winter 1995): 5.

${ }^{3}$ Salman Rushdie, The Moor's Last Sigh (New York: Pantheon Books, 1995), p. 206. 
wayang is together with and interacts with other plays (events, media, genres, etc.). It will become clear why discussing these aspects of the performance together is fruitful.

\section{Historical and geographical focus and the limits of the study}

My research has focused on the area traditionally associated with the city of Solo in Central Java, and what I say should be understood as being limited to describing wayang in that region; however, this very disclaimer misrepresents, by oversimplifying, the geographical range of this study. While there still are elements recognizable as belonging to particular regional performance styles-for instance, Yogyanese dhalangs 4 incorporate many Yogyanese elements along with many Solonese elements into their performances, performing thus in an ostensibly Yogyanese style-today most performances combine the various styles. The Solonese style in particular has a special place in today's Java; on the one hand, it is the most widespread and most influential of the various regional styles, and all the most famous dhalangs perform in it, or in a style based on it (such as the new Pantura [pantai utara, "North Coast"] style, which is basically the Solonese style altered by many radical innovations and the incorporation of elements from various regional styles). ${ }^{5}$ On the other hand, the so-called Solonese style is characterized by so much taking-in of elements from other styles that, while it is still associated with Solo and Solonese dhalangs or their imitators, it is basically a mixture of different elements from the various regional styles. Thus, the kind of performances that I have focused on are not only characterized by belonging to a particular region; they also constitute the style seen on TV most often, the style imitated everywhere in Java, while naturally some dhalangs try to resist its influence (which is merely another sign of its dominance). According to the inventory of the private television station Indosiar in Jakarta, which broadcasts wayang weekly, between August 1995 and April 1999 the station has broadcast 101 performances in Solonese style (Gagrak Solo), twenty-seven in Yogyanese style, and seven in the "North Coast" (pasisir) style, one in East Javanese style, and twenty-three performances of West Javanese wayang golek. ${ }^{6}$ The famous Solonese dhalangs perform more often outside the Solo area-in Yogya, Semarang, etc.-and outside Central Java-in Jakarta, Surabaya, etc.- - than in Solo, Solo being only one of the major locations of their performances, and this is another reason why the Solonese wayang must not simply be considered Solonese, and why it is not enough to think about the variety of styles in Java simply in terms of geography. This is not to discount the great variety of wayang

\footnotetext{
${ }^{4}$ Dhalang is the puppeteer, who is traditionally in charge of many aspects of the performance, and the one performer who has the most power and responsibility in shaping, building up the performance: he manipulates the puppets, enhances their movements with sound-effects, speaks their voices and narrates, directs the gamelan, builds up the plot of the narrative, etc., and combines the various components of the performance in such a way that they enhance each other and form a whole. He also functions as the "manager" of the group of performers.

${ }^{5}$ Naturally, not everybody is happy about the popularity and success of the Solonese wayang: it is thought of as a monopoly that threatens variety and the persistence of local identities. For the "intervention of [Solonese] puppeteers," see "Intervensi Dhalang," Kedaulatan Rakyat, September 1, 1996.

${ }^{6} \mathrm{I}$ am indebted to Didik Yulianto from Indosiar for the data. Indosiar's categorization of the styles is problematic, but it does give us an idea of the way that Solonese style is seen as dominant and encompassing other styles.
} 
performances in today's Java or the resistance to the Solonese style; rather, it is precisely because the situation is so complex that my work cannot be said to be limited to a single regional style. (In fact, even referring to Solonese style is an oversimplification: a number of distinct "sub-styles" can be distinguished in what is traditionally thought of as Solonese style.) However, because the questions raised below concern foreignness, including the foreignness to places, the association of the prevalent style with Solo as the "home" of the performances is relevant and useful to this essay. ${ }^{7}$ Moreover, in this essay I describe wayang in Java from the perspective of the Solonese style and in relation to it; scholars focusing on another regional style will have a different perspective.

A note on history. The focus of this study is the present. In most cases, when I refer to the past, I mean the immediate past (which is chronologically as vague as "the present") to which the present directly relates and reacts. So for instance, if I say that comedy in wayang has a stronger presence today than it had in the past, I am talking only about developments in recent years. Thus, I do not imply that the directions of the developments that I am tracing necessarily characterize wayang developments in more distant past, or that at certain points in history wayang did not possibly develop in directions different from those that I am tracing, for instance, from comedy to more focus on epic narrative. Also, when I talk about "new " trends, I am not suggesting that one could not find precedents for these trends in a more distant past (I point out historical precedents in some but not all cases). I merely imply that today they are (still) felt as new. ${ }^{8}$

\section{Preparatory Notes on the Present World}

The connection between innovations and the way that wayang is in the present world is made by Javanese authors writing on wayang and by dhalangs and other people reflecting on the innovations. It is common to explain the innovations in wayang as a matter of "going with the changing times," saying that wayang has to go with the times, or otherwise referring to the "present times" or the "world nowadays." On the one hand, this is a cliche that often serves only to explain away what is happening, or it is an excuse for failing to explain it. While one often hears comments about relationships between the innovations in performance and the changes in the world, it

\footnotetext{
7 Also, in related but rather more distant living traditions of puppet theater (other than Javanese) such as the Sundanese, Balinese, Sasak, or Malaysian forms of wayang, developments have been taking place that are often comparable with the developments in the Javanese tradition. My study, however, is limited to Javanese wayang kulit.

8 I will not argue that wayang is either traditional or modern, because-one could say-it is both. Nor will I avoid the terms, even though they are sometimes used so that they conceal more than they reveal. Single words, "traditional" or "modern," should not be blamed or banned-what matters is the way they are handled and the voice in which they are uttered. I will try to give a feeling for the complexity and liveliness of what happens. I will do so in part by showing how notions like traditional and modern, Javanese and foreign, local and global, among others, figure and take on specific associations and resonances in Javanese discussions and appreciation of wayang: in actual discourse-with its obsessions, quarrels, and misunderstandings - the terms and notions have their own kind of liveliness. But more central to my questions is what happens at the performance itself, which is always somewhat separate, though never quite, from the discussions about it.
} 
is more rare to hear exactly how these two connect. On the other hand, though a cliché, this phrase may suggest an initial question. Treated as an unanswered question (how does wayang "go with the times"?) rather than a frozen truism, it can open up the complexity of the way that wayang is in the present world, and the way that wayang is implicated (in a particular way) in the larger scene, this present world.

A focus on innovation will allow us to see only one aspect of the way that wayang is in the present world and interacts with the present world: it leads us to focus on a particular kind of opening of the performance, an aspect of what Gadamer calls "occasionality." At the same time, it has to be remembered that much of the wayang performance is in some way a past, or pasts; it is past in the sense that it remains standing, like a building, not unchanged, but partially unchanged. I will be discussing some extreme innovations, but one must keep in mind that in different performances, and in different parts of a performance, innovation is present to different degrees, and in all cases the newness is only one aspect of the performance. Moreover, as we will see, past and innovation are relative, because wayang has been constantly developing - there are newer and older innovations (as well as innovations that are not new anymore and thus do not feel like innovations). I am not saying that innovation is only like an alteration to a facade of a building, an alternation that leaves the building unaffected; rather, continuing the metaphor, I wish to investigate the complicated interaction between the being of the building and its new facade, the ways in which an old building is and is not deeply changed by altering its face. Speaking only about the facade and ignoring the building, or vice versa, would not even raise this problem. This is why I remind the reader to see this essay as dealing with a limited set of questions about wayang's being, and its being in the world. Focusing on innovations and their origin in the present will bring out only some aspects of the way that wayang is in the world. In another text (where a version of this essay is only one chapter), I look at many other aspects of the wayang performance, and see other important aspects of the performance and its being in the world. ${ }^{10}$

If our focus on innovation will provide only a partial view of the way that wayang is in the present world, then innovation can be only partially understood in terms of the interaction of the medium with the present world. It has to be explored also as an aspect of a creative activity, of work with the medium. In my dissertation, I described the performance as a work in progress, as a process of building-up; the work or the making of the performance does not function merely "behind" what is seen by the audience, but is visible and appreciated as an integral part of the performance. One could see innovation as another aspect of this process, an additional level of creativity, keeping in mind that innovation is not only "more work," but it may involve a different kind of work, with a different nature. At the same time, these two kinds of work, the two levels-making innovations, performing-are not clearly separate, for they go on simultaneously and may be accomplished by the same actions. Thus, innovation has to be examined both in its relation to the present world, and as an

\footnotetext{
${ }^{9}$ Hans-Georg Gadamer, Truth and Method, second revised edition, translation revised by J. Weinsheimer and D. G. Marshall (New York: Continuum, 1989), pp. $146 \mathrm{ff}$.

10 See Jan Mrázek, "Phenomenology of a Puppet Theater: Contemplations on the Performance Technique of Contemporary Javanese Wayang Kulit," PhD Dissertation, Cornell University, 1998. The study will be published as a book by the KITLV Press, Leiden.
} 
aspect of the making of the performance and its structure. Here I will focus more on the former, but I want the reader to keep in mind the limits of this approach.

The above paragraphs reflect a fundamental difficulty inherent in my terms. In my dissertation, I have described basic elements and aspects of a present-day wayang performance. They are structurally basic, but they are not essentially eternal or beyond time. I have described them as they are today, and what is basic, or some of it, might have been different yesterday and might change the day after tomorrow. In this essay I want to show how this present-day wayang performance fits into the present. That is: here we look at a relation between the present world and something that is itself a part of the present world, and I want to examine how this part interacts with the whole, how the whole motivates innovations in the part, and how certain parts or aspects of this part (the performance) are developed or annihilated in response to the character of the whole. The difficulty is that of looking at something that is itself of the present (wayang performance), looking at it as it is in the present world, and yet as if it were something foreign to the present world. I believe, however, that this is not only a difficulty inherent in my approach, but rather a fundamental difficulty in the way that wayang is, a difficulty with which it has to deal, and a difficulty that my approach brings out.

This has to do with the fact that the present world is itself full of difficulties, that it is not homogeneous, that different phenomena in the present world have different pasts (histories, memories, roots), and are thus somewhat foreign to each other, and that a basic characteristic of the present world is play among the different phenomena and their different pasts. It is inherently difficult to be in the present world because that world is inhabited by beings that try to tune themselves to something that constantly changes and are therefore always to some extent foreign in the world. In short, wayang, as it tries to be a part of the present world, is in a difficult position (and it is not alone). It is constantly challenged, constantly threatened. It has to be with other phenomena that have different ways of being and different pasts. Examining this "being with" will be a major goal of this essay. Moreover, this is not something unique to the performances I saw; wayang has always been in this difficult position. This constantly being in a difficult position, being a part of something and being with things to which it must try to tune itself (or to be with them in some other way), is what my approach reflects by suggesting that being in the present, and interaction with the present, is a part of the way that wayang is, and that it is merely a part of the way that wayang is.

I look here only at the present, and in that sense, my perspective is limited; but this does not mean that I can ignore the past, because the past (or pasts) constantly penetrate the present. To understand the way that wayang is in the present, I will have to look at these pasts as they figure in, or as they mark and shape, the present world. Here I will come nowhere near writing a comprehensive history of the innovations, but I will look at the histories of some of the innovations that are important today, and I will be interested in innovations as innovations, that is, in their newness; I will be thus looking at newness in the past and in the present.

What "the present world" exactly is is a difficult concept, because it is a difficult matter. Here, I would like to evoke less its primarily temporal meaning (though it is also always temporal), and instead evoke something like the general atmosphere, the 
general character of the "scene" or situation in which performances take place, and the way that wayang is on that scene.

\section{Preparatory Notes on the Clown Scenes}

At this point I have to say how the clown scenes fit into this discussion. Or rather, though we will see that it is impossible not to discuss the clown scenes when we discuss innovation, because innovation is in different ways associated with the clown scenes, I should like to make some preliminary observations on why this is so, and for that purpose we need to look at what the clowns scenes are. Clown scenes are characterized by a particular kind of opening to the present. They are, in many ways, a rupture in the performance structure, an opening within the structure. In his article on performance time (with focus on the time of a clown scene), Rene Lysloff aptly calls the clown scene "a rupture in the flow of time." $11 \mathrm{~A}$. L. Becker writes that the "clowns, using modern language, modern ideas, and modern behavior, step among the heroes and demons and gods like wide-awake men in a dreamworld."12 During the clown scene as performed today, only the clowns are on the screen, and they bring in the waking world. While at other moments the spatial relationships among the puppets and the way they are positioned and moved on the screen manifest the characters' relationships (status, family relationships, etc.), during, and only during, the clown scenes this strict order and structure of the space of the screen seems to disappear. In these times, moving in the space no longer articulates status and relations between characters (because during their scene, there are almost no status distinctions among the clowns), and nothing keeps the clowns firmly in place, in a stable "composition," in the structure. ${ }^{13}$ The clowns speak to each other Low Javanese, that is, the language that one uses when one does not need to heed the other person's status. During the clown scenes, music does not conform to the pathet (time/musical mode/mood), and today even with the Javanese laras (tuning; I shall discuss later the use of diatonic tuning), anything goes. What goes on in the clown scene has no direct relation to the plot. In terms of space, time, language, music, and narrative time, a clown scene is an opening in the structure, a relatively unrestrained moment. It is in the structure, in the sense that it is framed or surrounded by it, yet it is to a great extent free of its constraints. Thus innovations in performance penetrate most easily here, and performance is most open to the world around it during these times. In other words, during the clown scenes the performance is open in such a way that the surrounding presentness can penetrate most easily, as if without any consequence to the structure, without hitting against it.

As a background for an examination of how the clown scenes admit the present world, we should look at their recent history. The pasts of the clown scenes are not the same in the different traditions. Interestingly, in the Solonese tradition, the clown

\footnotetext{
11 René Lysloff, "A Wrinkle in Time: The Shadow Puppet Theater of Banyumas (West Central Java)," Asian Theater Journal 10,1 (Spring 1993): 60.

12 A. L. Becker, "Text-building, Epistemology, and Aesthetics in Javanese Shadow Theater," in Beyond Translation: Essays toward a Modern Philology (Ann Arbor: The University of Michigan Press, 1995), pp. 39-40.

${ }^{13}$ See Mrázek, "Phenomenology of a Puppet Theater," Chapter Two.
} 
scenes were less important than in some other traditions, specifically than in Yogya and Banyumas. While in some other traditions one clown scene, the gara-gara, is typically featured in every performance and stands independent of the particular play-and this is said to have been true even long ago-in Solo some fifty years ago (older puppeteers still consider this the Solonese tradition), the gara-gara was included only in certain plays where the plot required it, and no "exclusive" clown scene was added in other plays. This suggests that in the Solonese tradition the gara-gara was relatively more dependent on the story than in some other traditions, and was thus relatively more a part of the structure of the performance. Later, however, Solonese puppeteers began occasionally to follow other traditions in making the gara-gara a feature of any play, and today in Solo it is hard to imagine a performance without the gara-gara. Nonetheless, Solonese puppeteers, particularly the older dhalangs rather than the younger apprentices, still talk about it as something new in Solonese stylethough they acknowledge it is now becoming old-and call it the "Yogya style" or "Banyumas style" gara-gara. That the gara-gara, as a standard scene, is somewhat new to Solonese tradition, and that it is thought of as having been imported from another tradition, is significant, since we are interested in the opening of the gara-gara to the outside and the new. Moreover, while in the past the gara-gara consisted of only a few light gamelan ${ }^{14}$ songs with some comedy in between, more recently it has been expanded so that it often lasts close to two hours, and, in ways that I will discuss later, it has become radically more open and freer.

In addition to the gara-gara, another clown scene, the limbukan (the female servants Limbuk and Cangik star in this scene), has become increasingly important, and today it is in character basically identical to the gara-gara, even though it tends to be shorter and occasionally - though rarely-may be absent. Suratno, though focusing on the development of the limbukan in the nineties, traces its history farther back. ${ }^{15}$ The limbukan has developed from what used to be a short and rather insignificant element of the scene inside the palace, a discussion between two female servants, which has been gradually but radically extended and changed in character.

Against this background we can see that the clown scenes, in the present form, are new, but they have developed from old newness. The relatively structure-free opening to newness was occasionally present in the structure in the past, and it was present most significantly as a clown scene, but today it has been extended, has become more central and freer. An old puppeteer, Ki Gondotukasno, when I asked him what he feels is the most fundamental innovation in wayang, or what is most different about the performance, said that "now there is more innovation; now there is so much that is new." That is: innovation is nothing new; what is new is that there is so much innovation.

\footnotetext{
${ }^{14}$ Gamelan is the musical ensemble accompanying the wayang performance. Music is central to the performance: the gamelan plays during all parts of the performance, and its music is carefully integrated with the dramatic action and other aspects of the performance. See ibid., Chapter Four.

15 Suratno et. al., Limbukan Pada Pakeliran Wayang Purwa Gaya Surakarta Dalam Lima Tahun Terakhir: Tinjauan Tentang Kedudukan Dalam Pertunjukan, Perkembangan, dan Peranannya Dalam Masyarakat (Surakarta: STSI, 1996).
} 


\section{Guest Stars at Wayang: Innovations in the Clown Scenes}

Wong Jawa kepingin lagu landa; wong landa kepingin lagu Jawa. ("The Javanese desires a Dutch song; the Dutchman desires a Javanese song.")

- From song lyrics by Manthous ${ }^{16}$

Occasionally, one can still see a relatively old-style clown scene: several songs sung by the pesindhen (the female singer) or the dhalang, but ostensibly by the clowns, to the accompaniment of gamelan; and comic discussion in which only the clowns are implicated. I have mentioned that even here the structure "takes a break"-but at the same time much remains the same as in other parts of the performance: the puppeteer remains sitting, making the puppets alive with movement and his voice, he remains in charge of the performance and speaks only through the puppets, and the blencong (the lamp illuminating the screen) remains to be the theatrically central light. Below I will reflect on some of the basic changes in the clown scenes and their general characteristics.

Wayang music in "The Times of Mixedness" (Zaman Campursari): A Musical Image of the Mixed-salad-like Mixture (garap gado-gado) ${ }^{17}$

In 1990, a group called Campur Sari Gunung Kidul, or CSGK, under the leadership of Manthous (or Manthou's), began to rise into prominence, and soon its popularity "exploded," as an Indonesian newspaper put it. ${ }^{18}$ In the mid-nineties, I would be woken up early in the morning by my neighbors playing a tape of Manthous's CSGK. Later in the morning I would walk to the bus stop and pass a stall selling cassettes and playing CSGK at full volume; and as I got on the bus, I heard-what else-CSGK; only for a moment was the music turned down, as a young men with a guitar got on the bus and tried to make money, singing-what else-a song featured on Manthous's cassettes. There was only one thing that I, as a researcher, could do: buy some CSGK tapes and listen to them. In the evening, in a completely different atmosphere, in a village far from the city, the wayang screen and the gamelan instruments were set, ready for a performance celebrating a circumcision. Before the performance and during the clown scenes, a local Campursari group, one of the many imitating Manthous, contributed to the entertainment.

The word Campursari (sometimes spelled campursari, or Campur Sari) cannot be easily translated, but the part that stands out and determines the semantic meaning of the name is campur, "mixed." (Sari can have various meanings, but as one Javanese put

\footnotetext{
16 From the rap section of Manthous adaptation of the song "Ronce-Ronce," on side A of Ronce-Ronce: Campursari Kroncong Dangdut, audio recording (Dasa Studio).

17 The term "zaman campursari" ("times of mixedness") is used in Arie Sudibyo, "Biarkan Gamelan Alternatif Berkembang," Kedaulatan Rakyat, September 22, 1996.

18 "Campur Sari Bakal Jadi Musik Indonesia," Kedaulatan Rakyat, August 17, 1996. All translations, unless otherwise indicated, are mine.
} 
it, "the Javanese attach it to anything.") The term Campursari has been used in various context to refer to mixtures, medleys, etc., including musical mixtures. Today it is strongly associated with Manthous and his music.

The basic feature of (Manthous's) Campursari is that it combines Western and Javanese musical elements. Some manifestations of Western music have coexisted with gamelan in Java for hundreds of years, and on certain occasions have been combined. The Javanese palaces were always especially apt to assimilate foreign elements. In past centuries, Western instruments were played not only separately in the palaces, but also simultaneously with gamelan (being juxtaposed rather than combined), and in some cases they were even incorporated into pieces for the gamelan orchestra. In the twentieth century, Western and Javanese instruments, musical concepts, and tunings, interacted on many occasions. ${ }^{19}$ Thus, as Indonesian observers are quick to point out, Manthous's version has not risen out of nothing. Its uniqueness, and its relevance for our study, rests in its extreme popularity in the nineties, and its dominating presence in wayang and specifically in the clown scenes.

Campursari, as one of Manthous's singers puts it, is "a blend between gamelan music and kroncong." ${ }^{20}$ Kroncong itself, which is the "Western" ingredient, is a popular music tracing its history many centuries ago to the Portuguese presence in the archipelago. Both kroncong (in Malay/Indonesian) and a Javanese version of kroncong, called langgam Jawa, are common in Java, and popular especially with older peopleas a taxi-driver put it, they are sante ("pleasantly-relaxed"). Philip Yampolsky's descriptions of Kroncong and Langgam Jawa indicate that the genres themselves are far from being strictly "Western":

Kroncong [National]. A hybrid style mixing European harmonic and melodic elements and European instruments with Indonesian ideas of instrumental and vocal function and idiom. The typical ensemble is violin, transverse (Western) flute, guitar, ukulele, banjo or mandolin, string-bass, and plucked cello imitating drum-sounds. Other instruments (e.g., electric organ, trumpet) are sometimes added. 21

Further Yampolsky's description of langgam Jawa gives an idea of how this Javanese version of kroncong has "been together" with gamelan music. ${ }^{22}$

Langgam Jawa [Central Java]. A subdivision of Kroncong, popular mainly in Central Java. A prominent Langgam Jawa composer, Andjar Any, is said to have invented the genre in the 1960s. Strictly speaking, Langgam Jawa are songs in the Langgam form ( $\mathrm{AA}^{\prime} \mathrm{BA}^{\prime}, 8$ bars per phrase), sung in Javanese, accompanied by the kroncong ensemble, and using quasi-Javanese pentatonic modes drawn from

\footnotetext{
${ }^{19}$ For a history of this interaction, see Sumarsam, Gamelan: Cultural Interaction and Musical Development in Central Java (Chicago: The University of Chicago Press, 1995); see also my review of the book in Asian Music 27,1 (Fall/Winter 1995/1996): 153-56.

20 Quoted in "Lebih Mantap Sebutan 'Minul,"' Kedaulatan Rakyat, August 17, 1996

21 Philip Yampolsky, Lokananta: a Discography of the National Recording Company of Indonesia, 1957-1985 (Madison: University of Wisconsin, 1987), p. 43.

22 Often, Javanese do not make a clear distinction between kroncong and langgam Jawa: when they say kroncong, they often mean what is more strictly called langgam Jawa; also, langgam is also often used to refer to what Yampolsky and I call langgam Jawa.
} 
the diatonic scale. (All other forms of kroncong use heptatonic major or minor.) In practice, however, other Javanese melodies not in langgam form have come to be performed by the Kroncong ensemble, and by now "Langgam Jawa" means anything played as Kroncong and sung in Javanese. In general, Langgam Jawa is clearly imitative of Central Javanese gamelan-not only in mode but also in instrumental interplay-and sometimes gamelan instruments such as siter and ciblon drum are added to the ensemble. Songs composed as Langgam Jawa are now sometimes incorporated into the gamelan repertoire $[\ldots]^{23}$

Manthous's creativity seems to be not so much a matter of producing something radically new; rather, he has been able to make something mildly new very appealing, in part by presenting it as new. The mainstream music genres that are the basis of Campursari-kroncong, and especially langgam Jawa-are already hybrids, and have been subjected to much mixing; for instance, in the early 1980s, the number one langgam Jawa singer Waldjinah recorded a cassette series featuring langgam Jawa songs accompanied by gamelan. Still, Campursari, and its newness, are specially noted for being mixed.

When Manthous talks about his work, he tends to focus on two things: the importance of bringing Western diatonic and Javanese "pentatonic" tunings together (by "pentatonic" he always means Javanese gamelan tunings, rather than the diatonicbased pentatonic of langgam Jawa, which is in Western music theory sometimes called "the Chinese scale"); and the potential of his favorite instrument, the kibor or keyboard. Rather than tuning the keyboard to gamelan (as has been done in America), he tunes gamelan to the keyboard, and the melodic gamelan instruments that he uses (gender and siter) are tuned to a diatonic scale.

In an interview, Manthous says that Campursari is a blend of gamelan music and modern music [musik moderen], and

"the tones of the gamelan for accompanying Campur Sari must be truly in tune [laras] with the keyboard [ . . . ] For me, because Campur Sari is a combination of pentatonic [i.e., Javanese tuning] and diatonic music [Western tuning], the two have to really blend. I am very much against putting together elements of music in such a way that they are just put together. In other words, the blending of the pentatonic and the diatonic has to be harmonious [laras], so that it is good for gendingan [gamelan music], and also good for langgam," he stated while showing a Chromatic Tuner [in English and in italics in the original], an instrument for testing the tones by international standard [berstandar internasional]. ${ }^{24}$

The "international standard" (standar internasional) often figures as a major theme in Manthous's and other people's comments on Campursari, and Manthous is said to have "standardized gamelan" (menstandarkan gamelan). ${ }^{25}$ In the same way that English is said to be an "international language" (bahasa internasional), the keyboard scale is internasional, and therefore moderen, and therefore foreign, non-Javanese-though this

\footnotetext{
${ }^{23}$ Yampolsky, Lokananta, p. 44.

24 "Campur Sari Bakal Dadi Musik Indonesia."

25 See Otok Bima Sidharta, "Gamelan Tradisi, ya, Gamelan Standar," Kedaulatan Rakyat, October 20, 1996.

The term is also frequently used by Manthous.
} 
foreignness was present in Java longer than anyone can remember. Interviews with Manthous in the press provoked first comments by Otok Bima Sidharta (who works with acoustic music and gamelan, in a manner much more avant-garde and less mainstream than Manthous), followed by six more newspaper articles by different writers. In each of them, the conflict and possible compromise between Javanese and "international" tuning were discussed in terms of Javaneseness and foreignness, and in terms of the old, or traditional, and the new. ${ }^{26}$ Thus, musical tuning becomes involved in culture and politics. The mixture of different methods of tuning, which is, interestingly, often referred to in terms of "marriage" (mostly perkawinan, but also pernikahan), is often related to the mixture, or "marriage," of Javaneseness and foreignness. For instance: "Recently there has been someone [i.e., Manthous] who has married [mengawinkan] pentatonic tones and diatonic tones." 27 And: "[Manthous] had married [mengawinkan] Javanese taste to pop music [musik pop] which, nota bene, is a penetration [terobosan] of Western culture [budaya Barat]."28

Before, and even today, old Javanese and new international music spoke and speak different languages: "Traditional music speaks [berbicara] ning nong ning gung, while new music feels jrang jreng jring jreng."29 Manthous has been able to make this marriage, this penetration, very pleasant and very popular. Everybody admits this, though in fact the act of uniting these two sorts of music has serious implications if one remembers the cultural associations-and one is constantly reminded of them. This marriage, moreover, is not only a symbolic act, but has physical basis: it is a marriage of sounds, of "ning nong ning gung" with "jrang jreng jring jreng."

Manthous takes care that his music remains a mixture, a "marriage," that it is heard as a mixture. On the one hand, Manthous says: "Clearly, elements of traditional gamelan music are very much felt in Campur Sari music." ${ }^{30}$ However, while at one time Manthous considered making a completely "diatonic" gamelan (rather than using only a few gamelan instruments), he and his advisors decided against it, since he did not want "Campursari to become a kind of uyon-uyon [gamelan music] because [if a whole diatonic set were used] it [the music] would be dominated by gamelan." 31 Vocal parts are central in Campursari music-Campursari compositions are first of all songs-and Manthous also tries to articulate the mixedness of Campursari by his choice of singers. Two of his top singers were introduced in the newspaper article "The Harmonious Campursari Duo" in this way: "Lasmini comes out of the profession as a waranggana [pesindhen: female vocalist in gamelan music and wayang], while Minul began as a kroncong singer," and they were quoted saying: "Singing Campursari songs is indeed different from cengkok sindhenan [vocal patterns or style in gamelan music] and from kroncong patterns." 32

\footnotetext{
26 See articles in Kedaulatan Rakyat: August 25; September 15, 22, and 29; and October 6, 13, and 20, 1996.

27 Otok Bima Sidharta, "Standardisasi Gamelan Dengan Tradisi," Kedaulatan Rakyat, August 25, 1996.

28 "Bincang-Bincang Dengan Manthous: Pahlawan Seni Keroncong dan Masa Depan Gamelan?"

Kedaulatan Rakyat, October 6, 1996

29 Otok Bima Sidharta, "Standardisasi Gamelan Dengan Tradisi."

30 "Campur Sari Bakal Jadi Musik Indonesia."

31 "Bincang-Bincang Dengan Manthous."

32 Job, "Duet Serasi Campursari," Kedaulatan Rakyat, October 6, 1996.
} 
In addition to the emphasis on the "mixedness" of Campursari, both Manthous and others deal with another phenomenon: the keyboard. In practice, their diatonic tuning is actually the "keyboard tuning": "Intonation of the Campursari gamelan has been tuned to the keyboard intonation [intonasi keyboard]." 33 With its non-gamelan, "international" tuning, its electronic technology, and its association with different kinds of pop music, keyboard represents the new and the foreign, the moderen and the internasional: "Keyboard which has the same standardization [sama standardisasinya] everywhere in the whole world." 34 Moreover, the appeal of keyboard has another source, which is connected to its character, specifically to its character as brought out by Manthous's use of the instrument. According to one article, Manthous wants

the "source of sound" in Campursari to be in the power of [dikuasai] keyboard which he calls an extra special instrument because it can make the sound of whatever one wants! Not only gamelan is manipulated by this finger-press instrument, but also the sound of guitar, violin, flute, and cello on the stage are all produced on the four keyboards by Manthous and his younger brother Yuni. ${ }^{35}$

Manthous is obsessed with keyboard not only, and I think not primarily, because it is practical or versatile, but rather because of the idea that one instrument "can make the sound of whatever one wants." He enjoys the fact that a keyboard can "cheat," that it can trick people, that people think they're hearing a gender or a violin when actually they're hearing keyboard, and that even when people know it is the keyboard-and perhaps especially then-they still hear some other instrument, because after all the keyboard, as Manthous uses it, has no sound of its own. "I play with sampling. If on a tape people hear the sound of saron, slenthem, gambang [gamelan instruments], or the like-that is all from the keyboard,' [Manthous] says bursting into gales of laughter." $36 \mathrm{He}$ laughs because when people listen to keyboard, they think they hear something else than what they hear; they do not know what they really hear. That is very modern. In "traditional" gamelan one hears the resonating bronze, or the dhalang's or a singer's "sounding breath of the human voice, which is certainly the most stable-warm imaginable thing in the world of sound," 37 while in keyboard music one hears only reproduction, for its sound is the sound "of" something else. In an quotation above, keyboard is called the "pencet instrument." Pencet means to press, as in pressing a button-one presses a button and there is one sound, or rather the "sample" of a sound, one presses another and there is another sound. If one listens carefully enough, one may realize that music from a real violin or real saron is not being heard, that the music is all reproduction referring to a violin or saron which in reality-here Manthous bursts into laughter-is not there. But keyboard does not ask for this careful listening; it rather asks for labeling: "violin," "saron," and other buttons. Moreover, keyboard music, as used by Manthous, is a mixture par excellence, and like Campursari, it appeals to the audience in part because it is a mixture. "Sampling" - which is what Manthous "plays" ("saya bermain sampling")-is the beginning, and mixing is the rest.

\footnotetext{
${ }^{33}$ Ibid.

34 Otok Bima Sidharta, "Standardisasi Gamelan Dengan Tradisi."

35 "Bincang-Bincang Dengan Manthous."

${ }^{36} \mathrm{Ibid}$.

${ }^{37}$ Thomas Mann, Doctor Faustus, H. T. Lowe-Porter, trans. (New York: Alfred A. Knopf, 1948), p. 68.
} 
Keyboard resonates with the characteristics of Campursari as a whole, and we see that it deserves to be central to Campursari. On the other hand, keyboard is not everything in Campursari: the vocal parts and the vocalists, for instance, which are themselves "mixed," certainly contribute to the music. Nonetheless, since keyboard is important not only in Campursari but also in innovative wayang performances, a few additional comments on keyboard are due. First of all, an electronic keyboard is very expensive, and its appeal derives not simply from the music or sounds it can (re)produce, but also from its value: it becomes a sign of its own value. An article on new models of hi-tech electronic keyboards mentions that the majority of people who buy keyboards are "families," "and the rest are musicians." In this article, a musician is quoted: "At this moment, musical instruments are not simply a facility for playing music any more, but they have developed into one of the symbols of prestige." 38 The article, entitled "Music Technology, Don't Make it into a God or a Ghost," reacts to the fact that keyboard is made into a god or a ghost. Both its value, and the unique character of keyboard as discussed above, contribute to its status, its iconic qualities. Newness for the sake of newness (keyboard as an image of modern technology) is another reason for this, and another aspect of the appeal of the keyboard, as well as of Campursari. Manthous is aware of this: "In arranging songs, I am indeed oriented to the market. [...] Among other things, [I have to] produce new forms, remembering that today people are very critical and always demand something new."39

How is an examination of Campursari and keyboard relevant to our understanding of the clown scenes and innovation in wayang? Manthous's Campursari group itself is at times featured at large-scale wayang performances; they play during the clown scenes, and sometimes before the performance. When Manthous himself is to perform in a wayang performance, the few songs become a major attraction of the evening, the climax of the clown scenes, and, for many people, the climax of the whole event. While applause is a rather rare phenomenon at wayang performances, applause often breaks out when Manthous appears.

Manthous's Campursari group is often imitated, and because the musician only appears at major events, these imitations are the most pervasive form of his and his music's presence. Manthous's group is imitated in different ways. First of all, there are Campursari groups that may perform alone, but are commonly sponsored to contribute to a wayang performance, in very much the same way that Manthous's Campursari contributes to large-scale performances. They perform songs featured on Manthous tapes, as well as other langgam Jawa tunes. While they always have a keyboard, the keyboard tends to play a lesser role, though still an important one, and more "original" instruments may be used, both from the kroncong group (ukulele, guitar, etc.), and from gamelan (especially sarons and gong). Usually the sponsor decides whether to have a Campursari group at a wayang performance, and the dhalang must incorporate their music into the performance, specifically into the clown scenes. Also, the Campursari group may play before the dramatic performance, replacing the klenengan (gamelan music) that traditionally plays at that time. Manthous's group often opens a performance.

38 "Teknologi Musik, Jangan Dituhankan atau Dihantukan," Kedaulatan Rakyat, September 20, 1996.

39 "Campur Sari Bakal Jadi Musik Indonesia." 
At other times, the dhalang-this is especially common in the case of younger dhalangs, and has become increasingly common in the mid-90s-has his own keyboard and possibly other non-gamelan instruments, and these are used for, among other things, playing Campursari songs and imitating Manthous's group-the dhalang commonly mentions Campursari Gunung Kidul and/or Manthous by name. In this case, the gamelan tends to be much more involved. All instruments are usually playing. New styles of playing (or "treatment") have developed for different gamelan instruments used in Campursari pieces. The result is that the character of the music becomes rather different-less "chamber," noisier, often more excited, louder, less electronic. (See Figure 1)

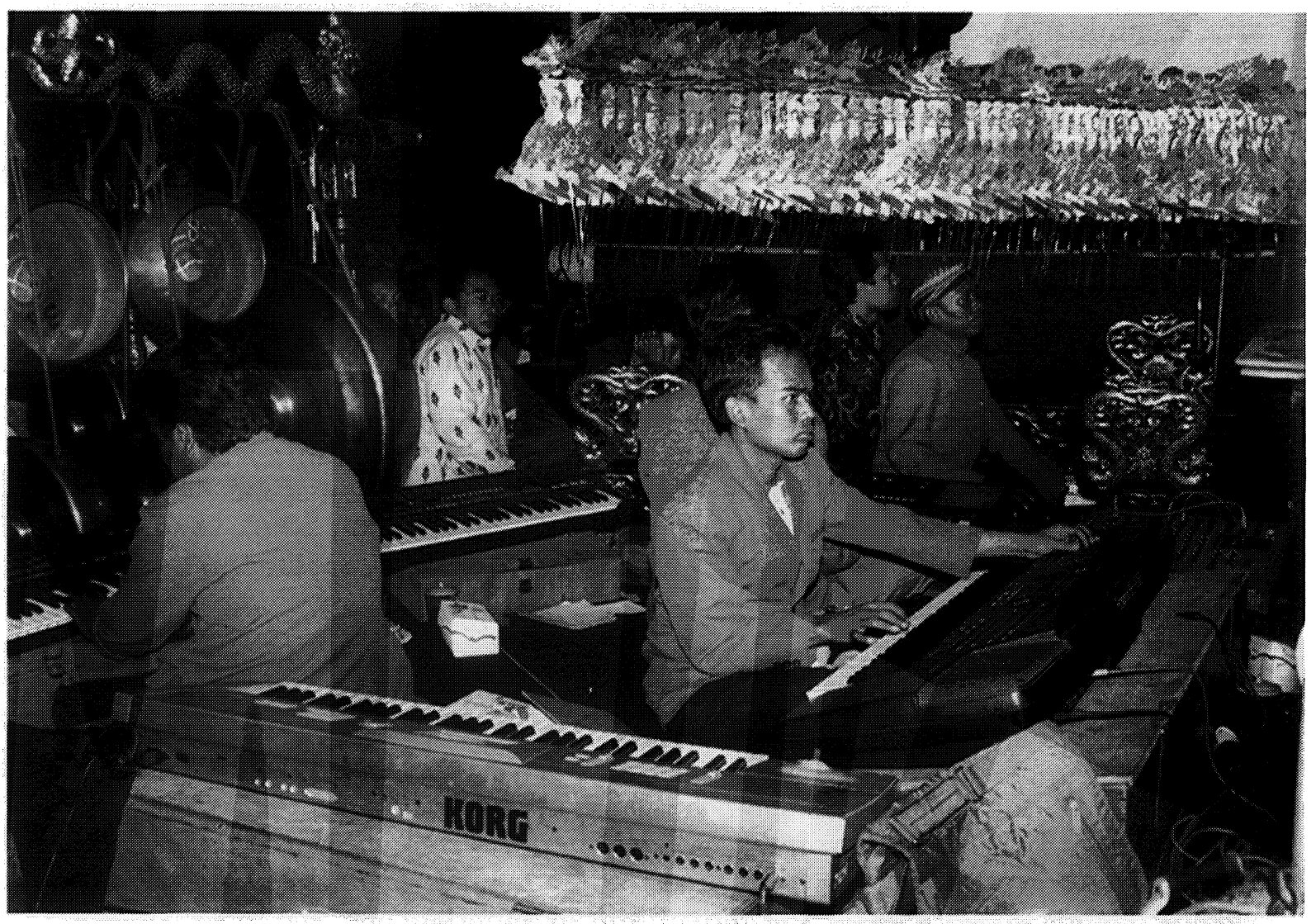

Figure 1

Campursari music has certain essential qualities in common with innovative clown scenes. "Mixed" - campur - would be the most general adjective to describe it. This kind of mixedness has a particular character. The "new," the "modern," the "international," the "standard" (I put these into quotation marks simply because I mean specifically the Javanese concepts) "penetrate" into or are "married" to Javanese musical and music-like theatrical structure or composition, into Javanese "tuning." At the same time there is some attempt to make the marriage laras (a word that Manthous 
likes to use)-harmonious, in tune, with connotations suggesting beauty and pleasantness-yet the mixedness itself is not covered up, but rather exhibited and enjoyed for its own sake, as are the newness of the new, the international-ness of the international, or the modern-ness of the modern.

I would like this to be understood in the context of what has been said about the clown scenes, particularly about their opening to the present world, which is always somehow foreign. The mixing of Campursari is a part of the same process. It is a matter of opening up to the outside which penetrates inside but does not disappear within. Rather the particular character or the phenomenon, new and foreign, is appreciated for its own sake, as is the penetration itself. The extension of the clown scenes, like Campursari, involves a particular kind of mixing and taking in: mixing-in the outside present world, the foreign, including the "international," the "modern" or the "standard" (standard as opposed to Javanese). In this sense Campursari can be seen as a musical image of the clown scenes and their interaction with the outside.

We must take into account the likeness between Campursari and the clown scenes when considering the presence of Campursari in wayang performances. It is most useful to see the relationship between Campursari and the clown scenes as an interaction between two phenomena that have much in common, specifically, both are characterized by a particular kind of mixedness and opening to the present. In this light, Campursari's presence in wayang becomes only one manifestation of a larger trend in wayang, and analyzing the character of this particular manifestation, as we have done, is useful to understanding phenomena in wayang that are not necessarily the result of Campursari's influence or impact, but rather that are in character similar to Campursari. In short: if Campursari is a little like the clown scenes, and if we understand a little about Campursari, we have a chance to learn a little about the clown scenes.

This innovative trend is manifested in other ways in the music chosen for wayang performances. In wayang, the mixing of non-gamelan instruments with gamelan is taking place in various ways, and clearly not all these experiments are directly indebted to the influence of Manthous, since new musik and keyboard were introduced in wayang performances long before Manthous's rise to popularity. ${ }^{40}$ Today, the first pieces in a clown scene tend to be played only by gamelan, but some of them may be adaptations of langgam Jawa songs for gamelan. Later in a performance, some kind of Campursari may be included, and even later, as the performance continues, a number of pieces may be played that are not from the Campursari repertory (that is, not kroncong/langgam Jawa), but rather are different kinds of popular music, most importantly pop Indonesia (which is considered one among the many Indonesian

\footnotetext{
40 For instance, in the mid-1960s violins and trumpets were used in wayang performances. (From personal communication with an old dhalang who wishes to remain anonymous.) In 1976 a magazine article "Sapto, Yogyanese teenager who married [kawinkan] wayang with rock and acoustic music," reported on an experimental performance that was all prepared, but at the last moment was prohibited by the authorities. See "Sapto, Remaja Yogya Yang Kawinkan Wayang dengan Musik Rock \& Akustik," Variasi, November 26, 1976, p. 42. A decade later, but still well before Manthous's Campursari, another article, "Rock Wayang, Brother," reported on a performance that took place in Solo and in which various Western instruments were used in addition to gamelan. See "Wayang Rock, Mas," Tempo, January 31, 1987, p. 74. Some musicians in Warsena Slenk's group say that they used "musik" mixed with gamelan in wayang before Manthous, while other say that they began to use it at the same time, or even later.
} 
54 Jan Mrázek

popular music genres), dangdut ("a fusion of Indian film music and Western rock"), 4 and rock. Dangdut especially, both in wayang and in general, is extremely popular. While Campursari songs are in Javanese, the latter songs are in Indonesian and the rock tunes either in Indonesian or English. Depending on the puppeteer, the song, and the arrangement, they are played either by a combination of gamelan and non-gamelan instruments, or played only by non-gamelan instruments. Keyboard(s) (sometimes as many as five, as in performances of Crazy Djoko; see Figure 1), electric guitar(s), rock drum set, and Indian-like drums for dangdut are used, sometimes all together, but also in other arrangements (Figure 2 shows a performance by a young village dhalang who uses one keyboard, two electric guitars, dangdut drums, and rock drum set, together with the gamelan). Next to the non-gamelan instruments, many dhalangs now have, in addition to the pesindhens, one or more "non-gamelan" singers, referred to as penyanyi ("singer" in Indonesian, as opposed to Javanese pesindhen or waranggana). Moreover, pesindhens now have to be able to sing not only traditional gamelan pieces, but also langgam Jawa (on which more later).

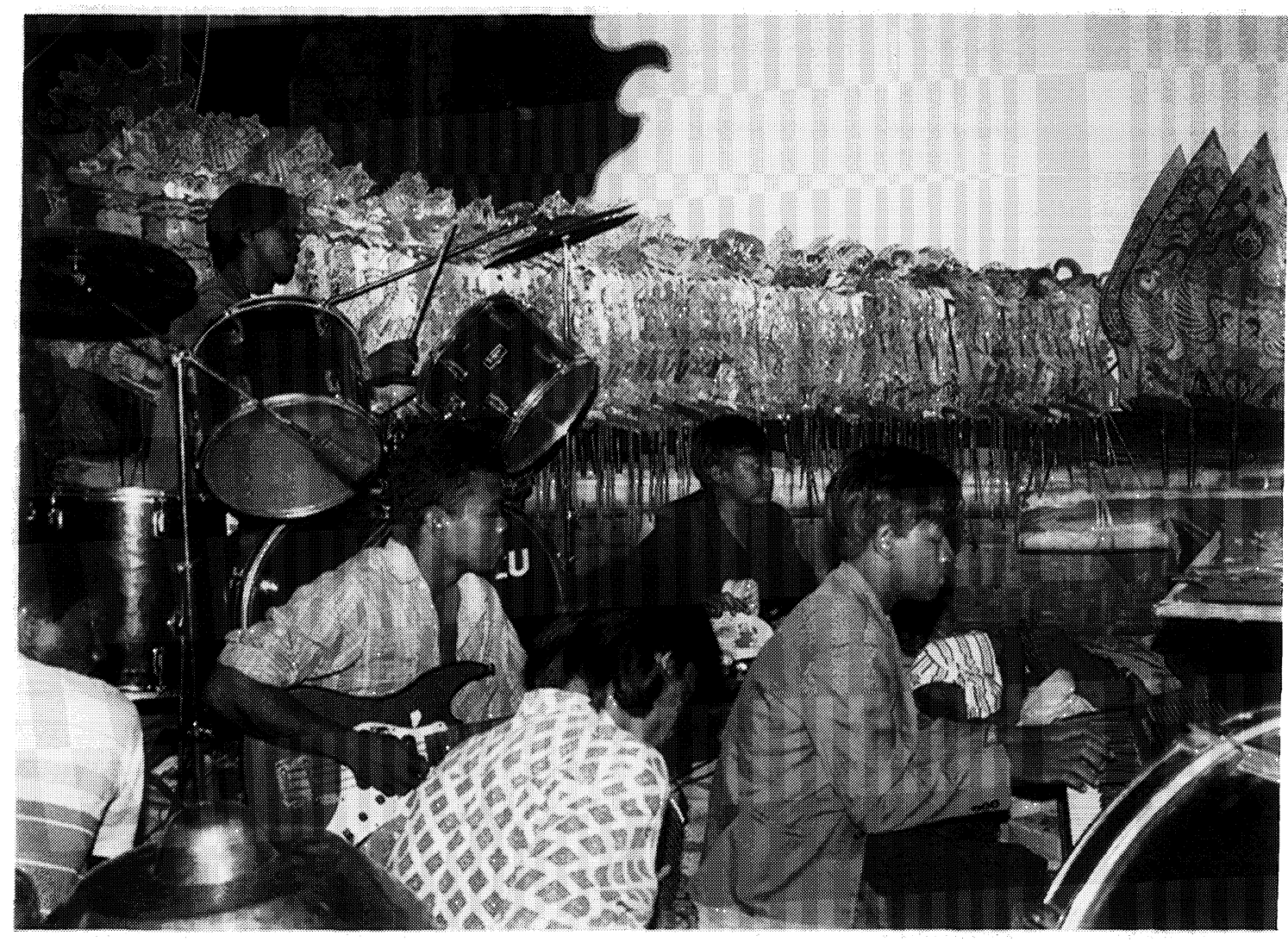

Figure 2

41 Yampolsky, Lokananta, p. 45. 
We can see that gamelan and non-gamelan instruments and music are mixed not only in single pieces (both Campursari and others), but also in the clown scene as a whole. A light gamelan piece, either more or less traditional, such as a jineman or lagu dolanan, may be followed by a few langgam Jawa songs, and then several dangdut or rock songs. In many cases, a Campursari song will have the first part in a langgam form, and the other has dangdut rhythm. Also, many pieces are played in a number of versions, and two versions of the same song are often combined in a single composition; for instance, the song "Caping Nggunung" is often played first as langgam Jawa and then it is "dangdut-ed" [didhangdhutke]. Warsena Slenk, one of the young dhalangs who focuses on music in the clown scenes, calls this (in performance) "garap gado-gado." The word garap is a word traditionally also used in music, meaning the particular way that a musical composition or its element is "fashioned" or "treated." The word gado-gado, which refers to a delicious and cheap mixed-salad-like dish, is often used metaphorically to refer to (as a dictionary puts it) something "consisting of various elements," while lagu gado-gado (gado-gado song) means "potpourri,"42 that is, a musical medley; there is no connection between the gado-gado dish and the literal meaning of pot-pourri, the "putrid pot." Gado-gado, when used metaphorically-a common practice-implies not simply a mixture, but a disorderly mixture, a mixture without any logic, spiced with irresponsible freedom. ${ }^{43}$ The same dhalang, Slenk, has been also using what he calls in performance a lagu medley ("medley song"), consisting of revolutionary songs and pop songs, played on gamelan and keyboard. The terms garap gado-gado and lagu medley, like Campursari, illustrate that the heterogeneity and mixedness is essential to many of the individual songs and to the scene as a whole. Apart from the mixing of tunings, musical instruments and idioms within musical compositions, the whole scene is a mixture, a potpourri, musically, and, as we shall discover, otherwise as well.

The incorporation of non-gamelan instruments and music needs to be seen as only an extreme form of a more general tendency to be open to the present world, to the outside: not only to the non-Javanese and to some degree the non-Indonesian (nongamelan, non-wayang), but also to things foreign on different levels, for instance, in Solo, to the non-Solonese. Let us examine a 1996 performance by Ki Anom Surotoone of the most popular puppeteers, a performer considered by the people to be the most Solonese, and, significantly, the only very popular puppeteer who does not use keyboard. In Anom's clown scene, first the musicians played several traditional light gamelan compositions. These were followed by a few langgam Jawa songs (some of them had appeared in Manthous's cassettes, but in the wayang performance they were accompanied only by gamelan instruments). In this part of the clown scene, there was one song, "Sapu Tangan," a composition of the late dhalang Ki Nartosabdho, which, as the puppeteer explained to the audience, "imitates Balinese style," and to which we will return later. Then the puppeteer said "now we head to West Java" and announced a Sundanese (West Javanese) jaipongan song (jaipongan is a West Javanese genre) which was then sung, in Sundanese and with the accompaniment dominated by the

42 John M. Echols and Hassan Shadily, An Indonesian-English Dictionary, revised and edited by John U. Wolff and James T. Collins (Ithaca: Cornell University Press, 1989), p. 166.

43 As one Javanese put it, in a definitely gado-gado language, it is ora terorganisir, not organized: "ora" means "not" in Javanese, "ter-" is an Indonesian prefix, and "organisir" is from Dutch. 
characteristic jaipongan drumming. For this purpose, Anom, like many other puppeteers, carries with him a set of jaipongan drums. Next, the dhalang said that now we would "go for a visit to Banyuwangi" (a town in East Java), commenting that "we have had here West Java, Central Java, and East Java won't be left out." He announced a song in "Banyuwangi style," and made clear that "we even have a drummer from Banyuwangi"; indeed Anom's troupe includes an East Javanese musician and uses an East Javanese drum. Next: "now we visit Madura" (a small island off East Java), and a "Madurese style song" was played, which, as the puppeteer pointed out, would be suitable to listen to while eating sate Madura, renowned as the best sate ayam [chicken satay] made by the Madurese (so that even some Javanese satay-sellers offer sate Madura asli-"the original sate Madura"). The clown scene concluded with the song "Anoman Obong." This song is significant to our discussion, for it combines passages of East Javanese music and West Javanese jaipongan (with some elements of rock), after an opening in (more or less) Solo-style solo singing (the combination of a solo vocal introductory section [bawa] and a vocalinstrumental piece that follows is itself a common practice in gamelan). There are other passages in the song that seem to refer to other regional styles, which I am however not able to identify; one Javanese listener mentioned kulintang. The title of the song is that of a well-known wayang play, and the lyrics, in Javanese rather than Indonesian, introduce it as "the story of the Javanese wayang" ["Caritane wayang Jawi..."]. A 1997 newspaper article describes the popularity of the song:

About "Anoman Obong" itself: it is not too much to crown it as one of the most popular songs in the last two years, even when compared with songs in the [national] pop Indonesia genre [that is, not only with regional Javanese pop]. How could it be otherwise; from adult people, to street children begging on buses, all really know by heart the lyrics of the song composed by Ranto Edi Gudel. [A Javanese commented on this sentence: "Of course they know it by heart-they hear everybody singing it all the time."] This song has already been translated into several versions, among others, gendhing Jawa (gamelan music), langgam [Jawa] and kroncong, dangdut, and even house music [house music]. ${ }^{44}$

The song "Anoman Obong" shares with the clown scenes performed by Anom's troupe the quality of having been touched by the introduction of another kind of foreignness, namely the introduction of non-Solonese regional styles. As with the introduction of non-gamelan instruments to a performance, an important part of the appeal of this style involves foreignness or outsideness for its own sake, and the mixture, too, is enjoyed because it is a mixture.

It must be remembered that our separation of these innovative practices-the mixing of gamelan music with non-gamelan (foreign or international) music, and the incorporation of gamelan music from other parts of Java or Indonesia into a clown scene or musical composition-is artificial, for both of these are aspects of the same larger process, the bringing in of the outside, the foreign. As noted in the quote above,

\footnotetext{
44 Muliawan Hamdani SE, "Lagu Pop Jawa Riwayatmu Kini," Suara Merdeka, July 24, 1997. I can add that in 1996 and 1997 this song was played in almost all wayang performances I witnessed; and that a Campursari version was also featured on one of Manthous's tapes.
} 
the song "Anoman Obong" has been played on gamelan instruments as well as on different mixtures of gamelan and non-gamelan instruments, where sometimes the nongamelan and sometimes the gamelan idioms dominate, and it has been part of Manthous's Campursari repertoire. In this one song, as in a typical clown scene, the different kinds of foreignness are brought in, and a mixture of, on the one hand, gamelan and non-gamelan instruments, and, on the other hand, a mixture of Solonese and non-Solonese gamelan music, are brought together. I am focusing on these two "sub-mixtures" only as on examples that give us an idea of the character of the larger, "general mixture."

We have seen that Anom announces to the audience where each of the nonSolonese songs comes from, and he even incorporates them in a larger project of presenting music from different places, which again he makes explicit verbally. The appeal of the music is not merely in the music, but also in its foreignness per se, in its origin from and reference to somewhere else. Certainly this reminds one of Manthous and others who emphasize that their use of diatonic tuning and of the keyboard is variously "international" or "standard" and involves "a penetration of Western culture." Those who argue for mixedness, for keyboard, for "international" tuning, never think of Western "penetration" as a threat, but rather as the "plus." Manthous explains the international associated with diatonic tuning in terms of geography, or ethnography, as when he speak about the "international standard" (standar internasional) of diatonic tuning:

"And what is most important, if the tones of the gamelan are already tuned [dilaras] [to the 'international standard'], it can be performed everywhere and will fit together [klop] with the tones of international music [nada musik internasional]. Combined with Italian ethnic music, it will klop; combined with Japanese music it will klop; combined with ethnic music [musik etnis] everywhere else which has been already tuned [to the international standard] it will still klop. Because in general the tones of ethnic musics in a number of countries have indeed already been tuned to diatonic tuning," says Manthous. 45

Foreign elements incorporated into their performances by innovators may be international, Western, or they may be non-Solonese. Elements that are musically foreign, and thus signify the geographically or culturally foreign, have a special appeal. Dhalangs are now accompanied by not only pesindhens, but also kroncong and popmusic singers. Also, some dhalangs, including the popular Ki Manteb Soedarsono, as well as Djoko Edan, the "Crazy Djoko," a younger and a more extreme innovator, have with them singers from other areas of Java, singing in a non-Solonese style. We have also seen that Anom, like a number of other dhalangs, have drummers from other parts of Java. I shall return later to examine the people who make the performance, but here I mention it only in anticipation of our gradual discovery that the conclusions made about music will apply to other aspects of the clown scenes, for not only music, but also people are brought in from outside, from other territories.

Another important idea that emerges from this examination needs to be made more explicit, for which purpose we must look at Campursari and other genres, as well as individual songs, not only as elements contained in the clown scenes, but rather as

45 "Harmonisasi Musik Masih Diabaikan," Kedaulatan Rakyat, September 7, 1996. 
musical phenomena that coexist in the same world with the wayang clown scenes. We ask how wayang, particularly the music in the clown scenes, is together with and among other musical phenomena in the present world. It has been mentioned that the song "Anoman Obong" not only mixes regional musical idioms, but also "has been already translated into several versions, among others, gendhing Jawa (gamelan music), langgam [Jawa] and kroncong, dangdut, and even house music," as well as Campursari, and each dhalang has his own way of arranging this song for either gamelan only, or a combination of gamelan and non-gamelan instruments. Indeed, most of the songs that become popular are performed in different genres, in different versions (called garapan: "manner of fashioning, treatment, [re]working"), and the new versions "become very different from the original." 46

If the different musical genres and even individual songs that penetrate wayang are mixtures, like the clown scene itself, it means that we must beware of perceiving these innovations as the results of one-way "influences" or "impacts" on wayang; rather we should try to see them in terms of interaction between mixtures, and in terms of being together in the same world. None of the musical genres, and none of the songs, have stable characters; songs are commonly "translated" from one genre to another, and genres constantly interact. Campursari, too, is not simply a mixture of gamelan and kroncong musical elements. Manthous says: "The beat ["beat" in English, italicized] of Campursari is the same as [the beat] of disco." 47 Another article on Manthous notes that in addition to "the existing langgam," in Campursari "we also hear the atmosphere of rock, reggae, gambang kromong [a Betawi, or Jakartanese, music genre], and other." 48 Another article describes Campursari as "a marriage [perkawinan] among various kinds of music such as kroncong, pop, gamelan music for wayang accompaniment [karawitan iringan pedalangan] and so on, that are treated in a dangdut rhythm." 49 Different tapes of Campursari present somewhat different mixtures (for instance, one cassette is subtitled "kroncong dangdut"), 50 and the recent tendency to play everything with dangdut rhythms rather than formerly more prevalent langgam Jawa rhythms is reflected in a new term, cadut (combination of CA-mpursari and dang$D U T) .{ }^{51}$ A rap section-in Javanese and accompanied by a dangdut beat-is also popularly incorporated into Campursari songs, as well as other songs, during the clown scenes. ${ }^{52}$ Thus the opening to the contemporary world, to the foreign, that characterizes the clown scenes also characterizes many other musical genres. It is not enough to say that the clown scenes take in other genres, because the other genres are already characterized by similar taking-in. Wayang elements, or references to wayang, too, are incorporated into other genres, or individual songs, as illustrated by the song "Anoman Obong," or by the fact that Manthous's Campursari and his compositions

46 "Maraknya Gaya Campursari Bangkitkan Keroncong," Suara Merdeka, September 12, 1997.

${ }^{47}$ Quoted in "Bincang-Bincang Dengan Manthous."

48 Th. Pudjo Widijanto, "Manthous, Mengendalikan Jakarta dari Gungungkidul," Kompas, February 28, 1997.

49 "'Uler Kambang' Pun Didangdutkan," Suara Merdeka, October 13, 1997.

50 Ronce-Ronce: Campursari: Kroncong Dangdut (Dasa Studio), 1995.

51 See "Uler Kambang' Pun Didangdutkan."

${ }^{52}$ See for instance Manthous's version of the langgam song "Ronce-Ronce," referred to above; some popular puppeteers, such as Crazy Djoko, also often incorporate Javanese rap into various songs. 
not only mix in "gamelan music for wayang accompaniment," but they are, in his words, "inspired [diilhami] by the works of Ki Narto Sabdo,"53 a famous dhalang and gamelan-songs composer. On his tape Jenggleng George (Jos) /Nyidam Sari ${ }^{54}$ Manthous at certain moments functions very much like a dhalang during a clown scene (talking to the female singer, telling her what to sing, making jokes, and so on), and one can hear a suluk ("mood song" used in wayang performance for dramatic purposes) with new lyrics, as well as other compositions strongly associated with wayang. Kroncong, the most apparent source for the music of Manthous, has made a comeback in popularity in recent years because the songs have been popularized again by Campursari, and because the style has been able to accommodate elements from other musical genres. In a newspaper article entitled "The Arrival of Campursari Style Revives Keroncong" from September 1997, we read:

The flood of Campursari albums in the market in the last two years has signaled a comeback of kroncong music in the country. In this development, kroncong also incorporated elements of other musics such as dangdut, jaipong, music of Banyumas [West Java], Madura, Banyuwangen [Banyuwangi-style: East Java], and so on. 55

It is this mutuality of impact, and the fact that none of the genres is stable but all are always in flux, that characterizes the interaction: between musical genres, and among individual compositions there is a constant traffic of musical ideas and elements, and these musical elements are not merely formal features, but they become references to other genres from which they have come.

The mixedness, the taking in of the foreign, is a matter of opening up to the present world and taking in its elements. However, this quality of mixedness itself can be seen as a product of the present world, of the foreign and new, and as something that is taken in. This can be seen if we look at the histories of specific cases of this mixedness.

For instance, the character of Manthous's music cannot be separated from his personal experience as a musician, and this musical experience is decisively conditioned by his not-only-musical life in the present world..$^{56}$ As a child, Manthous learned to play the cello and the guitar. At the same time, his grandfather was a professional gamelan musician, and his uncle a dhalang. When Manthous was in elementary school he was already playing gamelan, and often joined his uncle when his uncle was performing wayang, sometimes playing in the gamelan. "He learned each of the [gamelan] instruments, and understood the essentials of slendro and pelog [gamelan tunings] and the elements of ketawang, ladrang [gamelan compositional forms]-these are Manthous's basics [basic, in English, italicized]." 57 Before he was sixteen, he left his village in Central Java, and went first to Cirebon, a town on the border between West

\footnotetext{
53 "Bincang-Bincang Dengan Manthous."

54 Campur Sari Gunung Kidul, vol. 2, Dasa Studio, probably 1995.

55 "Maraknya Gaya Campursari Bangkitkan Keroncong."

56 From among the many newspaper articles on Manthous and CSGK on which my account is based, I recommend three that are especially informative: "Campur Sari Bakal Jadi Musik Indonesia"; "BincangBincang Dengan Manthous"; and Th. Pudjo Widijanto, "Manthous, Mengendalikan Jakarta dari Gungungkidul," all cited above.

57 "Bincang-Bincang Dengan Manthous."
} 
and Central Java which has a musical tradition and language that are often characterized as mixtures of elements from the two regions. Soon after that, in 1966, he moved to Jakarta, where he lived and worked for twenty-eight years. He had a long, active, and successful career as a musician in Jakarta. Jakarta itself, and music that comes from Jakarta, is associated with the non-regional, the "national," and thus with bringing musical and cultural elements together into one melting "putrid pot"; being associated with the supra-regional, it is hence the most "international" place (and is home to the most "international" music) in Indonesia. In 1969, Manthous became a member of a keroncong group, and in 1976 he founded a group called Bieb Blues, that was playing "funky rock," and he was also active in a gambang kromong group. He was involved with dangdut, and he is said to "create tricks [trik-trik] in the bass part that are now imitated by dangdut musicians." 58 He also composed and/or arranged a number of pop and kroncong songs, most importantly for the nationally famous singer Hetty Koes Endang, who "is noted for her unusual ability to sing in more than one style," a fact significant to our discussion. ${ }^{59}$ Manthous began experimenting with the idea of combining Javanese and Western music in the late sixties, but at that time his experiments went unnoticed. However, he was involved in combining different genres that were less obviously mixtures. For instance, he is named as the music composer on a cassette featuring the kroncong version of the originally pop Indonesia song Hati Yang Luka. ${ }^{60}$ Around 1990, Manthous's brothers back in his village were playing with combining gamelan and musik, and Manthous, with his experience from Jakarta, decided to work on developing it further. ${ }^{61}$

It would be too limiting to see Campursari only as a picture of Manthous's life. But it is also that, and for us the relation between the character of Campursari and Manthous's life is relevant because it shows one way to see the mixedness of Campursari as originating in the "mixedness" of the way that people-Manthous and others-are in the world, in the ways they travel and work beyond their birthplace, in the ways that their lives, and their world, are implicated in the world beyond their village or town or beyond Central Java, at the same time that this world remains foreign. Or, if one does not like the idea of Campursari being a "picture," one could look at it as an aspect of Manthous's life: Campursari is his work. The characteristics of his work share some of the characteristics of his way of being in the world, and in that sense the Campursari music, and this person's way of being in the world, are intimately connected.

Dhalangs are in the world in a similar way, and if Manthous's music can be seen as a reflection of his life, or as his work, so dhalang's innovations-such as the incorporation of Campursari or other foreign music into the clown scenes-can be seen in relation to their way of being in the world. We can take as an example the late $\mathrm{Ki}$ Nartosabdho, one of the most notably innovative dhalangs in his own time, whose

\footnotetext{
58 "Manthous, Mengendalikan Jakarta dari Gungungkidul."

59 Philip Yampolsky, "Hati Yang Luka, an Indonesian Hit," Indonesia 47 (April 1989): 10.

60 See ibid., passim, for a discussion of this song and its translation, musical and lingual, to a number of regional genres. See also ibid., illustration on p. 11.

61 Since we have seen-and will continue to see-the popularity and implications of the "marriage" metaphor, it is interesting to note that Manthous is reportedly married to an American woman, though this fact is never publicized. I am indebted for this information to Jody Diamond (personal communication).
} 
innovations still inspire and are still imitated by many other dhalangs, and whose work has inspired Manthous's own work. Let us look specifically at Nartosabdho's own musical compositions, which he began to use in the clown scenes in the late sixties. ${ }^{62}$ Sumanto, in his biography of Nartosabdho (based mostly on interviews with Nartosabdho's friends and collaborators), connects Nartosabdho's music to his experiences:

Gamelan music in the style of other regions [i.e., non-Solonese], such as Banyumas [West Central Java], Pasundan [West Java], Yogyakarta, Bali, and Surabaya [East Java], as well as the dance-accompaniment gamelan music from the ambiance of the Surakarta palace, had also had an influence on Nartosabdho's wayang accompaniment. With the group Ngesti Pandawa [a wayang orang group in which he was a drum player, and more or less a music director], Nartosabdho was always on the move from one town to another, giving performances. In each town, Nartosabdho certainly came into contact [bergaul, "socialized"] with the gamelan music living [hidup] in that town. Moreover, he was asked by Sastrosabdo [the director of the group, and Nartosabdho's mentor] to absorb gamelan music of other regions by means of bringing in a teacher from other regions such as Banyumas, Pasundan, Surabaya, and Bali. Thus it is not strange if Nartosabdho's works were influenced by gamelan music from other regions, and in his wayang performance he brought in [memasukkan, "entered"] compositions from other regions. ${ }^{63}$

Nartosabdho's compositions, and specifically his uses of musical elements from "other regions" (daerah lain) are connected with his way of being in the world: specifically his frequent travels and his "socializing" with music "living" in "other regions."

A number of Nartosabdho's compositions do not simply borrow musical elements from other regional styles, but instead present these "foreign" musical elements for the sake of their foreignness. For instance, I mentioned "Sapu Tangan," a song by Nartosabdho, when I was describing the clown scene in a performance of Anom, and noted that Anom himself described this song to the audience as one that "imitates Balinese style." In Anom's performance of this song, as in Nartosabdho's own recording, ${ }^{64}$ some of the instruments are played with different, harder mallets, which produces the sound associated with Balinese gamelan, and the fast ornamentation also superficially but clearly resembles the fast figuration characteristic of Balinese gamelan. Other techniques, too, imitate Balinese musical elements. However, "Sapu Tangan" is by no means a Balinese composition, and the way it "imitates" Balinese gamelan is both superficial and ostentatious. The Balinese elements are not there simply for their formal characteristics. They are also signs of foreignness; they are meant to declare "this is an imitation of Balinese music." This is in certain ways like producing violin sounds on the keyboard. Many other Nartosabdho compositions display other kinds

\footnotetext{
62 For musicological examination of some new gamelan compositions, see Judith Becker, Traditional Music in Modern Java: Gamelan in a Changing Society (Honolulu: The University Press of Hawaii, 1980).

63 Sumanto, Nartosabdo: Kehadirannya Dalam Dunia Pedalangan, Sebuah Biografi (unpublished S-2 [MA] thesis, Universitas Gadjah Mada, 1990), pp. 98-99.

64 Hear Paguyuban Karawitan Jawi, "Condhong Raos," directed by Ki Nartosabdho, Lumbung Desa: gendhing-gendhing karya Ki Nartosabdho, sound recording (Lokananta Recording ACD-127), side B, number 9.
} 
of foreignness, including "strange" (such as East Javanese) dialects in the lyrics of the songs. Moreover, the vocal part of "Sapu Tangan" is in the langgam Jawa style: thus, "Sapu Tangan" is also-in a slightly different way from Manthous's compositions-a mixture of (Malay+Portuguese+Javanese) langgam Jawa and (Balinese+Javanese) gamelan.

It is interesting to note that Nartosabdho's "Sapu Tangan" was the title song on a tape published in 1978, subtitled "Waldjinah Accompanied by Campursari." 65 Waldjinah is the most famous langgam Jawa female singer (recently, she has recorded with Manthous's Campursari, and she is a very popular and very expensive guest star at large-scale wayang performances, where she sings langgam accompanied with gamelan). The music on the 1978 cassette, while predominantly gamelan music, incorporates various non-Javanese-gamelan elements, including violins, and in its version of "Sapu Tangan," it includes Balinese musical elements. Thus, well before Manthous's Campursari, Nartosabdho's music was already seen and categorized as Campursari music, and was a part of the Campursari tradition.

Judith Becker, who writes about Ki Nartosabdho in conjunction with $\mathrm{Ki}$ Wasitodipuro, another Javanese composer, makes us aware of one more way in which Nartosabdho's compositions are distinctly foreign, or non-Javanese:

On the taped version directed by the composer, nearly all the melodic instruments drop out the second time through, leaving the two gender playing alone with wooden mallets, Balinese style. The third time through, all the instruments join in again. This did not occur spontaneously; it was planned that way. The manipulation of orchestral sound, found again and again in new style gamelan music, is a feature of Western music. In traditional gamelan music, the way an instrument is played depends on tradition; when it is played depends on the style of the piece and the irama, never on the whim of one man. No traditional gamelan director has the power of a Western composer or conductor. [ . . . ] The emergence of the composer, as one who creates a composition in full detail, directs the composition, and whose name is attached to the composition, is an innovation in Java leading away from an oral tradition. Both Ki Wasitodipuro and Ki Nartosabdho sometimes actually conduct the gamelan during rehearsals. Traditionally, musical direction is always covert, never overt. [ . . . ] Some of the old communality has gone; a certain amount of individual autonomy has been surrendered. 66

One could add that in some gamelan styles from other regions, such as Balinese music (especially kebyar, which is itself relatively new, though predating Nartosabdho's works), the details are much more pre-composed and composition-specific than in Javanese gamelan, and the orchestration is manipulated almost as it is in Western traditions. also, one could say that if there is one individual in Javanese music who has great authority in directing and changing the flow of music, even often relying on his "whim," it is the dhalang, and Ki Nartosabdho later became a dhalang. But Becker certainly makes an important point in saying that the idea of composing a piece, and of precomposing the different details (rather than leaving the "filling in" up to the

65 Saputangan: Waldjinah Diiringi Campursari, sound recording (Kencana Record IR-013).

66 Judith Becker, Traditional Music, pp. 76-77 
individual musicians who work within a tradition), is probably a result of an interaction with Western musical idiom, and certainly it is foreign to the Solonese tradition in which Nartosabdho was most at home. Thus, the idea of musical compositions such as those composed by Ki Nartosabdho, was certainly felt to be new and foreign to the Solonese gamelan tradition.

Nartosabdho's compositions are for the most part songs, and this is another way in which they seem foreign. The term "song" fits them well (they are often called lagu, in Indonesian/Javanese), which is not the case with most Javanese gendhings, which can be perceived as "compositions" or "pieces," and in which, in most cases, a single vocal line does not predominate the way it does in Nartosabdho's compositions, in pop songs, or in kroncong songs. The exception in gamelan music relevant here is the gamelan sub-genre called lagu dolanan, or children's song (lit. "play song"); these lagu are all predominantly vocal, are singable, and are frequently sung without gamelan. When accompanied by gamelan, they are often used by older dhalangs in a clown scene. Nartosabdho also composed and was clearly influenced by existing dolanan songs, but the song-ness of his compositions was inspired by other sources as well.

One of these sources-of both the "song-ness" of his compositions, and some of the other new and foreign ideas mentioned above-might have been Nartosabdho's experience with non-gamelan music, specifically kroncong:

In this new [Catholic] school Soenarto's [Nartosabdho's] artistic talent continued to develop. He had an opportunity to learn to paint, to sing kroncong songs, and to play guitar and violin. Later he joined the kroncong group [orkes kroncong] Sinar Purnama. He appeared at every performance, mesmerizing the audience with his sweet kroncong songs and enchanting violin playing, as well as his attractive guitar playing. He could play guitar behind his back and behind his waist. ${ }^{67}$

Thus, as in the case of Manthous, Nartosabdho's innovations, specifically his bringing in foreign elements and ideas (from "other regions," daerah lain, as well as from kroncong) can be seen as a reflection of Nartosabdho's way of being in the world: his biography.

Please note the character of the "progression" of this discussion, specifically about the interaction among different genres and creative personalities. What have we learned? On the one hand, Nartosabdho's opening to foreign musical elements (without direct mixing of gamelan and non-gamelan instruments) has been imitated-or has inspired-many dhalangs, including Anom, who go even further bringing in the foreign. Both Anom and Nartosabdho are imitated by other dhalangs. Compositions by Nartosabdho, who is more famous as a dhalang than as a song composer, have inspired Manthous's Campursari, have been featured on Manthous tapes, and they continue to be popular in clown scenes. ${ }^{68}$ On the other hand, Manthous's own songs are now introduced into wayang, and his Campursari is imitated. On the one hand, we have traced some characteristics of Nartosabdho's composition to the influence of non-

67 Interview with F. X. Suharso (Nartosabdho's friend), summarized in Sumanto, Nartosabdo, p. 24.

68 For instance, the song "Ojo Lamis" is both popular in wayang and featured on Manthous's cassette. See CSGK, directed by Manthous, vocal by Anik Sunyahni \& Manthous, Ojo Sembrono (Dasa Studio), side B, number 1. Another song by Nartosabdho, arranged for Campursari by Manthous, is "Prau Layar," on Ronce-Ronce: Campursari Kroncong Dangdut, sound recording (Dasa Studio), side B, number 6. 
gamelan music, such as kroncong, which he played as a child, though he spent most of his life as a gamelan musician and became famous as a dhalang. On the other hand, Manthous's works-mixtures of kroncong and gamelan-were inspired not only by Nartosabdho's gamelan compositions, but also, as he himself notes, by his experiences as a child with gamelan at his uncle's wayang performances, though a major part of Manthous's career was on the pop-music scene in Jakarta; and, as we have seen, "gamelan music for wayang accompaniment" is cited as one of the many ingredients of Manthous's Campursari. ${ }^{69}$ We may notice a kind of circularity, or rather zigzagging, in this discussion. This zigzagging reflects the mutuality of influence in the present world that I have pointed out above.

I use Manthous's and Nartosabdho's biographies, and the connections between their biographies and their work, only as two examples to help illustrate that the mixedness of music in the wayang clown scenes can be directly connected to the way that people are in the world (though Nartosabdho is not personally in the world any more, his way of being in the world, like his music and other aspects of his wayang performances, anticipated current developments). For this purpose, I use Manthous and Nartosabdho not only as examples of musicians (both involved with wayang), but of two people being in their world.

We have seen that Manthous emphasizes the importance of truly matching Javanese and "international" tuning, and in his group he tunes gamelan instruments to the diatonic scale. But most of his imitators do not tune the gamelan to the keyboard, and in the coexistence of the two different tunings one can hear a musical conflict that results from mixing. It is a pronounced conflict, because the difference between the tunings is usually clearly audible, and for some people at least, including Manthous, and including many Javanese musicians with whom I've spoken, it is disturbing. It is precisely because of Manthous's focus on tuning, and on the laras of the mixture, that we have to take this conflict seriously, and so does he. In an interview for an article (focusing on new music in wayang) entitled "Harmonization of Music Still Neglected," Manthous

said, that up to now the music arrangers/composers [penggarap, from garap] of compositions in innovative wayang performances still disregard the laras [tuning; being-in-harmony-with-each-other] and harmonisasi ["harmonization"] of music. Even though, if one wants to create a performance which is truly harmonious [harmonis], the problem of laras [in italics] must be given priority. "But so far not only arrangers of music for wayang performance have been disregarding the laras of the pentatonic and the diatonic. A number of Campursari groups, too, have up to now ignored the aforementioned harmonization. Thus, people who understand music will be able to differentiate easily which is Campursari Gunung Kidul (CSGK) which I arrange [garap], and which is Campursari which calls itself Campursari just to call itself Campursari," explained Manthous. ${ }^{70}$

And:

69 See the passage quoted above from "'Uler Kambang' Pun Didangdutkan."

70 "Harmonisasi Musik Masih Diabaikan." 
[Campursari] is a mixture between gamelan and keyboard. "For that, the pitches of gamelan for accompanying Campur Sari have to be truly laras [in italics] with the keyboard," explains Manthous. According to Manthous's observations, so far Campursari groups [other than Manthous's] have not paid attention to the laras of gamelan with keyboard, even though that is very important for the success of a Campur Sari performance. "As far as I am concerned, since Campur Sari is a blend of pentatonic and diatonic music, therefore the two have to really blend."71

Laras, a Javanese word in an Indonesian text, is the word that Manthous constantly uses to describe the desired harmoniousness, the being-in-tune of the blend. It is a word that I have discussed extensively elsewhere as a Javanese musical term, ${ }^{72}$ but what is relevant here is that laras is an essential quality of Javanese music, that it is what the music consists of (tuning, that is, harmonious relations among tones), and that it is a term used in other contexts as well to describe harmoniousness, the state in which one thing fits the other. Thus, if Campursari is laras, it is somewhat like Javanese music - even though it is laras in a "standard" or "international" (non-Javanese) wayand the "marriage" between the Javanese and the "international" (the foreign) is, in a Manthous presentation, harmonious. But if every other Campursari troupe does "not pay attention to laras," as Manthous puts it, this means that the "marriage" between the international and the Javanese is not harmonious. One might argue that since the Campursari groups "do not pay attention" to the lack of laras, we should not either; that the lack of laras, so to speak, does not exists. But, to counter this argument, it is important to remember that all the "imitation" groups are inspired by Manthous, and they-or the dhalang, when they perform in a wayang-make their connection to Manthous and his group explicit verbally, and nobody questions Manthous's role as the originator of "this" Campursari. In fact, their popularity depends on their reference to Manthous and his tapes, for Campursari and Manthous have now become Sony-like or Coca-Cola-like trademarks which people buy (patronize) simply because it is Sony, Coca-Cola, or Manthous/Campursari. If we want to see what happens to Manthous's music in the world, it is relevant to discuss the presence of conflict and lack of laras in most performances of Campursari. This is the kind of lack that tends to be noticed, like the lack of a comfortable shoe: it is a lack that manifests itself as discomfort and conflict, here specifically conflict between two musical tunings.

What are the implications of the resulting musical conflict? If we remember that Manthous, as well as commentators, repeatedly described his music as a "marriage" between the Javanese and the foreign, then the musical conflict suggests that there is a difficulty in the "marriage" which surfaced as soon as Manthous's music went deeper into the world. While one of the reasons for the popularity of Campursari was that it offered a manifestation of a successful, harmonious "marriage" of the Javanese and the foreign, when the "marriage" was attempted by other Javanese-those who lacked the experience of living for twenty-eight years in Jakarta-it did not exactly fail, but was discovered to be difficult ... though no less fascinating or popular for that. A Javanese author writes about the history of the "marriage" before Manthous. Note his choice of metaphors:

71 "Campur Sari Bakal Jadi Musik Indonesia."

${ }^{72}$ See Mrázek, "Phenomenology of a Puppet Theater," Chapter Four. 
In those years, LMI [Lembaga Musik Indonesia: a music institute] wanted to make a gamelan with $\mathrm{Do}=440 \mathrm{~Hz}$ [i.e., diatonic], after they observed how the pentatonic-diatonic marriage [perkawinan pentatonis-diatonis], with the abovementioned Yogyanese artists as the "priests" ['penghulu'], has never been harmonious [harmonis]. And yet, this marriage full of conflict [perkawinan penuh konflik] has nonetheless been going on-even now in the times of Campursari [zaman Campursari]-and produced children, the new creations [kreasi] of the artists still playing hide-and-seek in the jungle of slendro-major-pelog-minor. ${ }^{73}$

In the same article, the author makes clear that this "marriage" and its conflict is not simply a matter of a technical problem, or only a Javanese problem, yet he puts it into the context of the conflict between "the hegemony of Western music [hegemoni musik Barat]" and "people's music" in different Asian countries. He says that "people's music" does not have

the power to reject Western logic [logika Barat] which moves stealthily behind their [i.e., Western] hard and extremely aggressive cultural invasion [invasi kebudayaan].[ ... ] The marriage continues, precisely because musics of Pakistan, Japan, Thailand, and other countries have not the strength to repel the progress of Western music which, since some time ago, has been inspiring awe and penetrating everywhere. ${ }^{74}$

This, by the way, is an article that defends Campursari and the "marriage" in general (it is entitled "Let the Alternative Gamelan Develop"); it is not a condemnation, but rather an observation on the state of the world, and a justification for the "marriage" in such world. It is important that here both the harmoniousness of Manthous's Campursari (specifically the blend of Javanese and international tuning) and the conflict in the disharmonious "marriage full of conflict" are both interpreted in relation to cultural terms, connected to the conflict between a Western "cultural invasion" backed and made powerful by "Western logic" and "people's music" in different Asian countries. The difficulties and conflict of the musical "marriage" are a part of, or a reflection of, the conflicts in the present world. All but one Campursari group are characterized by this musical conflict, by the lack of laras, and in the music one can hear the conflict in the world.

The foreign as it figures in this conflict is apparently the non-Indonesian; but we have seen that things non-Javanese, and the non-Solonese can also be relatively foreign. I have pointed out that the foreign is often defined geographically. Yet "foreign" can have other aspects as well:

He [Manthous] acknowledges: the tones/tuning of gamelan (the pentatonic) in general indeed still give a priority to rasa [feeling: italicized in original, probably to mark it as a Javanese word], while the diatonic tones/tuning have an international standard [standar internasional]. ${ }^{75}$

Rasa (feeling, taste, sublime sense), such as the one that plays role in tuning Javanese gamelan, is thought by Javanese to be something essentially Javanese. As something

\footnotetext{
73 Arie Sudibyo, "Biarkan Gamelan Alternatif Berkembang," Kedaulatan Rakyat, September 22, 1996.

$74 \mathrm{Ibid}$

75 “Harmonisasi Musik Masih Diabaikan."
} 
Javanese, it is contrasted to the international. At the same time, it is not merely "ethnic" or "geographical," but it is-like its English equivalents "taste," "sense," or "feeling" -also something that is deep and central to (Javanese) human sensibility, to a person's "feeling," to a person's physical and psychological identity. A Javanese dictionary relates the word to the tongue, the body, and the heart. ${ }^{76}$ Manthous opposes rasa to the international standard. This suggests that the foreign is not only defined geographically or culturally, but is foreign also in a more personal sense; something can be foreign to "my" identity, to "my" sensibility, to "my" tongue, heart, and body. It is to this that the "international standard" is opposed and "married" (tuned, or, more commonly, not tuned).

By the way, are we speaking here only of metaphors of music, or about the music itself? I strongly believe that the metaphors bring out what is actually present in the music. The musical conflict is unquestionably real. The connections that people make between the musical conflict and the conflicts in the world-specifically between the (Central) Javanese and the foreign-may seem less obvious, but one needs only to remember what has been said about the appeal of Campursari to see that they are no less real. Both the foreign and the Javanese are appealing (in different ways) to the Javanese, as is the mixedness, both in Campursari and in the present world. The conflict, the "being-out-of-tune," in the world is not so much pictured as it is manifested in Campursari. People like to listen to music which they realize is out of tune. "The marriage full of conflict is nevertheless going on"-and we understand why so many people want it to go on, and are ready to live with the conflict, in this-or so the music would suggest-inherently difficult marriage.

But mostly only theorists, and people who dislike this kind of disharmony (including many performers, who would prefer to play gamelan exclusively and live without keyboard) focus on listening to this conflict. Other people do listen to the mixture, and enjoy it as such, but they do not specifically listen for the conflict; they listen to gamelan instruments and techniques, and they listen to the keyboard and other non-gamelan instruments at the same time, but not to their not-being-in-tune. They try to ignore the wholeness of the whole, because the whole lacks wholeness. The result is a kind of selective listening, listening that separates and often does not put things together, but rather keeps them separate, and enjoys them separately, though at the same time. The music is not, as Manthous says, "truly mixed [benar-benar campur]."77

We have seen that Manthous-style Campursari is not the only mixture of gamelan and non-gamelan music present in wayang. Pop Indonesia, dangdut, rock, and other songs also often combine the two musics, and what we have said about imitations of Manthous music, and their conflicts, applies to these other instances as well. These latter cases, by the way, are no less important in wayang today than Campursari.

The innovations in wayang are the object of much talk and the inclusion of musikthat is, non-gamelan music-in the forms discussed above is felt to be an especially radical innovation. It is loved by those who like musik; it is criticized by those who attend to (and enjoy) the wayang performance as a whole. In one performance I saw,

76 W. J. S. Poerwadarminta, Baoesastra Djawa (Groningen: J. B. Wolters, 1939), p. 521.

77 "Bincang-Bincang Dengan Manthous." 
the sponsor asked the dhalang "to keep to the etiquette [tatakrama]" at least in the first of the two clown scenes. The dhalang complied by playing only gamelan and Campursari pieces in the first clown scene, rather than musik without gamelan (he actually announced that he did so because the sponsor asked him to keep the tatakrama). Another dhalang said in a performance that he always includes gamelan, even in his arrangements of pop and rock songs, and thus does not go "too far" (durung kebablasen). Thus, performing musik exclusively in wayang is considered much more radical, and even impolite, "against etiquette," than including a mixture of gamelan and non-gamelan pieces. This cannot be explained if one looks at the songs as separate compositions, for at least some of the pop and rock songs sound undeniably better played by musik only, as fans of these songs contend. It is when one looks at these songs in the context of the performance that one realizes why many people insist on including gamelan. For even when musik is played without accompanying gamelan instruments, it is nonetheless part of a mixture, mixed in among other pieces that are played on gamelan, in one super-"putrid pot" or super-medley. In a more traditional clown scene, even though the constraints of pathet (mode) are relaxed, the gamelan continues playing in a gamelan laras, a gamelan tuning, and the sound of gamelan instruments also contributes to the belongingness of the clown scene to the whole, which, in musical terms, I have elsewhere called a "super-composition."78 In other words, a more traditional clown scene is to some extent a break in the dramatic and musical structure, but it is nonetheless connected into it, more connected than musik is. With musik, the break is much more radical, for not only the pathet, but also the laras is given up, as is the gamelan-ness of the gamelan instruments. But when the gamelan instruments are played with the rock band, though each single composition might sound terrible, in the larger context the hybrid music seems somewhat less radical, for at least the gamelan, and with its tuning, its laras, which is also the laras of the performance as a whole, "continues" playing.

Let us take a moment to consider why the sponsor and the dhalang, quoted above, think about these interactions in terms of tatakrama. Musik, especially musik played alone, is a break in the structure of the wayang performance. One of the aspects of the structure is a representation of people in the way that they are in the world, including the etiquette of being in the world (Javanese tend to emphasize this later aspect). In wayang what is represented (human behavior) is an integral part of the structure, of the medium, and, even, the "larger scene," the space in which the sponsor, performers, and the guests are together; what's more, the way they relate to each other-etiquette is an important part of this-is closely connected and implicated in the structure, in the medium. The clown scene is itself a break in the structure: musically, dramatically, and lingually (the clowns speak in low Javanese to each other, and impolite or obscene words are common). Musik in the clown scene presses the disruption a step further (in the words of the dhalang, it goes "too far"), making a much more radical break in the super-composition, in the structure of the whole performance event of which etiquette-as represented on the screen and as present among the people watching-is one aspect. Thus, musik is, in a strangely direct way, a break in the etiquette, in the relations among people. This is one reason why musik in wayang is by some seen as impolite or even obscene.

${ }^{78}$ Mrázek, "Phenomenology of a Puppet Theater," Chapter Four. 
But let me return to the kind of "selective listening" that the conflict between tunings calls for. I would like to look at a particular composition. It was performed many times by Warsena Slenk, a younger brother of Anom, and a dhalang especially popular for his inclusion of pop songs in his clown scenes. Slenk announced it as lagu medley, "the medley song," and it consists of songs originally set in a diatonic scale, sung to the accompaniment of gamelan and a keyboard. What is interesting about this particular medley is that it combines elements-ideologies, one could say-that are so unlike, and yet nobody seems to mind it. Mixed in among Revolutionary songs and rousing, patriotic songs, often marches, about the development of the country, is the ideologically opposed song "Pria Bujangan" ("The Single Man" or "Bachelor"). Here is an awkward translation of the lyrics (the original is in a clean, simple Indonesian):

Such is the fate of being single:

To go wherever one wants, as long as it's fun,

No one prohibits anything,

One is happy even without money, aw-aw

One is happy even without money.

What's difficult about being single:

Just singing everyday, never ever is one sad,

One is happy even without money, aw-aw,

One is happy even without money...yee-hoo! ${ }^{79}$

This song, all the rage in 1996, celebrates the pleasures of living without family responsibilities, ${ }^{80}$ enjoying oneself even though one has no money and thus little status, enjoying personal freedom, and in general, living only for the pleasure of living-all delightfully unlike the ideologies of the nationalist songs in the medley. In short, it is an anti-establishment song set in the midst of songs celebrating the establishment of the establishment. I find the juxtaposition rather like the juxtaposition of the two musics; in either case, one does not listen to the conflict, one listens separately to the different items in a medley, never bothering to connect them. Indeed, if one made the connections, if one related the fragments to the whole, in this case relating the antiestablishment song to the patriotic marches, it would feel at least impolite or incongruous. But connections and associations are not called for.

When I asked somebody if he feels a conflict between the "Single Man" and the content of the other songs, he replied that nobody listens to the content of the revolutionary songs, and that what is important is the joyful atmosphere. This kind of joyful, bustling atmosphere, without and apart from any meaning, is especially important in the clown scene. If meaning and medium generally tend to be integrated in a more harmonious way, "tuned" to each other in the other parts of a wayang

79 Begini nasib jadi bujangan/ Kemana-mana asalkan suka/ Tiada orang yang melarang/Hati senang walaupun tak punya uang, oooo/ Hati senang walaupun tak punya uang. Apa susahnya jadi bujangan/Setiap hari hanya bernyanyi/ Tak pernah hatinya bersedih/Hati senang walaupun tak punya uang, oooo/ Hati senang walaupun tak punya uang...yiiiihuuu!

I am indebted to my wife for helping me recollect the lyrics.

80 In New Order Indonesian official discourse, the state liked to be seen as a family, so that one had a status and place in society only as a "bapak" or an "ibu," "father" or "mother." See Saya Shiraishi, Young Heroes: The Indonesian Family in Politics (Ithaca: Cornell Southeast Asia Program, 1997). 
performance, the clown scene is both a break in the structure and in the wholesome meaningfulness; fragments are presented that are not meant to be connected. ${ }^{81}$

The above section has focused on only one aspect of music in the clown scenes, the mixedness, its character, and the way it is a form of opening to the foreign, to the outside. There is much more to be said about other aspects of music, and I will discuss some of them later.

Wayang among Other Media, Genres, and Shows; the Changing Roles of the Dhalang and Other Performers; and The Changing Character of Space

In the preceding discussion of music in the clown scenes we had to consider musical genres "foreign" (on different levels) to Solonese wayang both as components of the clown scenes, and as genres that are together with wayang in the same world, and which interact with each other as well as with wayang. When we now look more broadly at what happens during a clown scene and at the different innovations, we will need to see how wayang interacts with other shows and media presentations popular in the present world, both those considered traditional and those considered modern (the difference between these two categories is rarely clear-cut). These will include various relatively traditional (non-puppet) dramatic genres (wayang orang, kethoprak, ludruk, Sri Mulat, dhagelan) as well as media presentations, shows, or events that tend to offer themselves as modern, such as radio, TV, movies, sports, pop-music concerts and variety shows, karaoke gatherings, teater (Western-style theater), and so on. By giving attention to the interaction between wayang and other shows, I hope to elucidate wayang's opening to the present world, to the foreign. (The interaction with other media has had a powerful impact not only on the clown scenes, but also on other parts of the performance; in this section I limit myself to examples from the clown scenes, and I will discuss other manifestations of this interaction in the section on dramatic developments.)

A major development in the clown scenes can be seen by looking at the role of the dhalang. ${ }^{82}$ In contemporary clown scenes, it is now common for the speech of people other than the dhalang to be incorporated inside the performance frame; comedians, singers, and other "guest stars," as well as the sponsor or a member of the audience, may speak to the puppets and/or the dhalang, or to each other. The microphone plays an important role here: "to speak on the stage" means speaking into a microphone; the microphone bestows special importance or centrality on the speaker. The dhalang is only one among a number of speakers speaking into a microphone, so that he becomes only one of the "actors."

It would be an oversimplification to say that, in the past, the puppets were the speakers but now "living actors" have usurped their role. However, the change does

${ }^{81}$ Again, we are dealing with a tendency, and there is a danger that my text may make the distinctions seem more clear-cut than they are. Even in traditional gamelan, in many cases the lyrics are not widely understood; nonetheless, in the case described here, we are dealing with texts in contemporary language that are well-known and very easily understood, and yet the meaning is ignored.

82 The changing role of the dhalang is briefly discussed in Helen Pausacker, Behind the Shadows: Understanding a Wayang Performance (Melbourne: Indonesian Arts Society, 1996), pp. 36-37. 
concern the puppets. In more traditional performances, even in clown scenes, the dhalang speaks "through" the puppets, and it is the puppets who are understood to be speaking. Even when the dhalang speaks as the narrator, the "narrator's voice" is no more simply the dhalang's own voice than when he speaks through a puppet (there is no narration in the first person, and the dhalang never says " $\mathrm{I}$ " during the narrations). The dhalang never speaks "alone," but instead always gives over his speaking voice to a character or the narrator. Similarly, the dhalang's movements are always "given to" the puppets, and his own movements are connected to the puppets. The dhalang's movements and (obviously) the things he says are a part of even a traditional performance: the puppeteer is never quite invisible. However, an "organic bond" between the puppeteer and the puppet is central to the puppet theater. ${ }^{83}$ While the puppeteer animates the puppets, it is the puppets, or rather his connection to them, that gives him the right to speak, and he speaks in a voice that is both his own and theirs, and moves only to the extent required to manipulate the puppets. In sum, the dhalang in wayang has always been speaking and moving, and this has been an integral part of the theater. What is changing-or more specifically, loosening-is the puppeteer's connection to the puppets, his dependence on them. He-as well as other living persons-can now speak without puppets. Thus, it is not the puppets, but rather the organic bond between a living person and a thing that is temporarily given up.

At certain moments and in a certain sense, the microphone seems to be taking the place of the puppets, replacing them. If traditionally the dhalang derives his authority from his connection to the puppets, now, in some cases, the performers acquire a similar authority from the microphone and from the amplification-reproduction-of their voices. However, the speaker is not connected to the microphone in the same way that the dhalang is connected to the puppets. The microphone is very much like the keyboard in that it has no voice of its own, and yet it is in power. A wayang puppet requires a particular kind of voice, and the dhalang has to shape his mouth and vocal organs, his body, to produce that voice so that, as one dhalang described it, the dhalang's voice "enters" or is "incarnated" in the puppet; but any voice will "go through" the microphone. Or at least that is the implicit claim of the microphone-"I only amplify what you say." In contrast, the puppet claims: "It's me who is speaking."

Even in the exorcist ruwatan performances (as I have discussed elsewhere), ${ }^{84}$ the dhalang is never speaking alone. The event requires that the identity of the speaker remains ambiguous (whether it is the "dhalang-in-reality" speaking or the "other" dhalang represented by a puppet on the screen), and in this sense it is again both the dhalang-in-reality and a represented character (the represented divine dhalang) who speaks, and the dhalang, in a complex way, derives his authority to speak from the character represented by a puppet. In the clown scenes, there is often a similar ambiguity: people refer to the dhalang either as "Pak Dhalang," or by his name, or by the name of one of the clowns (Mbak Limbuk, Mas Gareng, and so on). When they refer

\footnotetext{
83 See Mrázek, "Phenomenology of a Puppet Theater," Chapter One and Three. The term "organic bond" is inspired by: "[T]he principal difference between puppet theater and live theater is the organic bond between puppeteer and puppet." Petr Bogatyrev, "The interconnection of two similar semiotic systems: The puppet theater and the theater of living actors," Semiotica 47, 1-4 (1983): 59.

84 Mrázek, "Phenomenology of a Puppet Theater," Chapter Seven.
} 
to him by naming a character that he represents, some kind of connection still exists between him and the puppet; if they refer to him as Pak Dhalang (unlike in the ruwatan, no dhalang is represented here by a puppet) or by his name, the connection is severed, and the dhalang becomes another "star" among many. Interestingly, the latter phenomenon is becoming more common, especially in the case of more moderen performances, and it is a sign of the gradual attenuation of the bond between the dhalang and the puppets. In the clown scene, the dhalang, momentarily disconnected from his puppets, becomes more like an actor in "living actor's" theater, and he interacts with other actor-like figures.

This disconnection is never permanent: the dhalang returns periodically to speak the voices of the clowns. We are talking merely about several moments within the puppet theater. However, these moments, and their development into a major attraction, are symptoms of a more general tendency in wayang. Also, these developments are referred to by those who dislike them as examples of the "collapse" of wayang. Typically, such critics speak about these developments as symptoms of the loss of the dhalang's power.

How are they so? Traditionally, the puppeteer, organically connected to the puppets, is unquestionably the most important performer, and he is the person who has the authority to direct the various aspects of the performance. This does not mean that other people are not involved in decisions; the sponsor and even other performers may offer suggestions, usually before the performance, which the dhalang takes into account and which may affect various aspects of the performance. However, it is the dhalang who has the executive powers, practically unchecked by anyone except by tradition. (The tradition recommends that a puppeteer conform to the sponsor's wishes, which are generally communicated very politely and without overt authority ["it might be nice, if you don't mind"], but in the execution of these wishes the dhalang has full authority.) The trend signaled by the inclusion of "guest stars," such as singers and comedians who speak to the dhalang, necessarily gives some of this executive power to other people. The comedian on the stage, for instance, talks to the dhalang as an equal, he participates in shaping the flow of the dialogue, and at times the puppeteer may even stand outside the main flow of conversation that takes place between two comedians, or between (a) comedian(s) and (a) singer(s).

It could be argued that the musicians have always had some degree of executive power when executing the dhalang's orders, and I agree that this could be interpreted as a difference in degree; what's more, we will see that music and musicians have been important in these developments. At the same time, this difference in degree is sufficiently radical to deserve attention (as can be seen from the controversies to which it has given rise). It has rendered the comedian's authority much more visible. At certain moments designated by the dhalang, who is now obliged to designate these moments, the comedian's executive powers equal that of the dhalang's, andespecially in the case of a dhalang who does not want to or finds himself unable to talk to the comedians as an equal, that is, to become another comedian-the dhalang may then be left "speechless"; at such a time, the dhalang does not participate in any way in shaping the moment of the performance, apart from designating when the comedian(s) can start his/her/their show and when to end it. For the dhalang this is not only a loss, but also a gain: the guest stars are generally a major attraction of the 
performance, and their inclusion in the performance (or the dhalang's consent to this inclusion) is a strategy to make the performance a success. Many dhalangs today owe their popularity - which in turn is source of their power - to their ability to incorporate guest stars into the performance. I suggest, then, that while it is true that the dhalang loses certain kind of power as a result of this innovation, he gains another kind.

To understand the phenomenon better, and to see how it fits with other developments, it will be useful to sketch the history of this development, studying it in conjunction with another major development: the increasing prominence of the female singers (pesindhens).

Old dhalangs, when asked about wayang in the past, tend to emphasize that there were fewer musicians and fewer singers, if any. In an interview for a Javanese magazine, Ki Naryocarito (Pak Naryo) is reported saying:

In the past, dhalangs did not have with them too many musicians, and did not have pesindhen(s) yet. It was enough to have ten to twelve musicians. Now it is different. There can be as many as fifty musicians and singers (including the guest stars) 85

Pak Sutino (Ki Hartokocarito), a dhalang in the Eromoko area whom I visited soon after this interview was published and who happened to have read it, was saying to his friend, as if with some nostalgia, when they were smoking their cigarettes: "That's right what Mas Naryo says. In the past there were not pesindhens like now. There was only the dhalang." Another old dhalang, Ki Gondotukasno from the Klaten area, said that in the forties and fifties there was only rarely a pesindhen at a wayang performance, and that the decision to include one depended generally on the sponsor: "If the sponsor was not rich, he could not afford to hire a pesindhen." Similarly, he explained, while the pelog gamelan, in conjunction with the more standard slendro, has occasionally been used for longer than he can remember (he is about seventy now), normally only slendro was used, and pelog was added only when the sponsor specifically asked for it, and when he could afford the extra expense of renting one. Given such responses, one realizes that it is not very useful to look for the precise date when something was invented in order to write the histories of the various developments; rather, it is important to see how the developments were, and others still are, spreading slowly, and to note that their diffusion tends to be gradual. For the researcher, it is perhaps more relevant to learn about the character of the diffusion than to try to discover the precise date of the first occurrence of a phenomenon. Keeping that in mind, it is interesting to note that Pak Naryo told me that pesindhen was first used in radio broadcasts of wayang in the late forties, and in an article in Jawa Anyar he is quoted saying:

At that time [during the war] dhalangs still did not have any pesindhens. So the vocal was from [sung by] the dhalang himself. When there was a wayang

85 Purnomo, HS, "Ki Naryocarito: 'Dhalang Saiki Akeh Sing Nglirwakake Bobot,'" Jawa Anyar 14/5 (July 20-August 4, 1997), p. 18. 
performance in RRI [Radio Republik Indonesia] Surakarta after the independence, they used a pesindhen/pesindhens, and that was imitated by other dhalangs. ${ }^{86}$

Whether or not Pak Naryo is right about the time of the introduction of pesindhen (probably he is not), his observation points to two important factors. First, it calls attention to the role of radio and the later recording industry. Ethnomusicologists seem to agree that the use of the microphone tended to make the pesindhen prominent. For instance, Judith Becker wrote in 1972 about conditions at that time:

Given the state of Javanese economy, hardly any one owns several high-quality overhead mikes. Nearly always, there is only one available standing mike. Practice has established that it is to be placed in front of the pesindhen, or female singer. This automatically makes a soloist out of the pesindhen with the gamelan relegated to an accompanying role. ${ }^{87}$

And R. Anderson Sutton writes:

The commercial recordings one hears of Javanese gamelan music involve close miking of the female singers (pesindhen). And perhaps in response to the recorded model, amplification of the female singers in live performance is practically universal. 88

It is clear that recordings and radio broadcasts of Javanese gamelan, competing with recordings and radio broadcasts featuring songs and singers, were instrumental in giving the pesindhen the position analogous to the singer in "Western" music (e.g., kroncong), and in giving her the microphone. On the other hand, there is an evidence that the dancer-singer, Javanese precursor of the pesindhen, held a prominent position in various non-dramatic music/dance performances. ${ }^{89}$ This is something that needs to be researched in greater depth, and which is beyond the scope of this work, but for our purposes we can note that it is likely that radio played a role in making the pesindhen's inclusion common, or perhaps more common, in wayang performances. Pak Naryo's statement tells us something about the diffusion of the pesindhen: pesindhen took part in wayang performances on the radio, and radio performances were imitated by dhalangs. This interaction with radio, and broadcasting media in general, foreshadows what

$86 \mathrm{Ibid}$. When I asked Pak Naryo if he knew whether there were broadcasts of wayang kulit before the war, he said he thought not but he was uncertain because at that time it was rare for common people to have a radio.

87 Judith Becker, "Western Influence in Gamelan Music," Asian Music 3,1 (1972): 4.

88 R. Anderson Sutton, "Interpreting Electronic Sound Technology in the Contemporary Javanese Soundscape," Ethnomusicology 40,2 (Spring/Summer 1996): 252.

89 See especially R. Anderson Sutton, "Who is the pesindhen ? Notes on the female singing tradition in Java," Indonesia 37 (1984): 119-133.

Laurie Sears, in Shadows of Empire: Colonial Discourse and Javanese Tales (Durham and London: Duke University Press, 1996), claims that the pesindhen was important in wayang performance in the nineteenth century, but she presents no evidence to show that this was generally true. Whether her hypothesis is true or not, it is clear that all old dhalangs agree that when they were young (let's say, in the 1930s), the pesindhen either was not used at all in wayang performances, or was not an essential feature of the wayang performances, and was much less prominent than now. Thus, while it is perhaps possible (though unlikely) that the female singer had special importance in times before what old dhalangs today remember, it seems clear that in the first half of this century, specifically in wayang in Central Java, the pesindhen did not have a strong presence, which is relevant here. 
would later become a decisive factor in wayang's development. Also, considering the importance of the microphone in contemporary performances, it is interesting to see that the microphone played a role in the past as well. Pak Naryo connects the use of microphone to the radio station, and also to President Sukarno's use of microphone in the early days of the Republic, and it would be interesting to research further the microphone's associations with power and leadership. And since I believe in the truth of jokes, I have to mention how, on one occasion, a Javanese comedian offered a quasipsychoanalytic interpretation of the microphone as a phallic symbol. To celebrate the circumcision of his son, the dhalang Anom Soeroto sponsored a performance in his house. One of the comedians pointed to the large microphones hanging above the stage and said that these were symbols (symbul) especially suitable for the circumcision ceremony, and signified that the boy would soon become a strong man. This makes one think not only about Sukarno and his microphone, but also about the connection between the microphone and the female singer, and her combination of erotic and (micro)phonic appeal. (Later in the essay I will discuss the growing importance of the pesindhen's sensual appearance in wayang.)

While it is not necessarily important for our purposes to point out specific individuals who helped initiate these various musical developments, one person is consistently mentioned in discussions about the pesindhen's increasing prominence in wayang performance. That is Ki Nartosabdho, whom we have noted as the composer and dhalang who began to mix Javanese and other musics in compositions presented in his wayang performances. His innovations, most of them introduced in the fifties and especially sixties, were later imitated and built upon by the most famous dhalangs today, who find themselves in turn imitated by other dhalangs. Ki Nartosabdho transformed what used to be a short conversation between two female palace servants into a new clown scene, the limbukan (which is now one of the two major clown scenes, and often lasts as much as an hour), and he began to include songs in the limbukan, including his own compositions, though, as Suratno points out, Nartosabdho's limbukan was much shorter than the usual limbukan today. 90 Another important development attributed to Nartosabdho is seating the pesindhens in a prominent position near the screen to the right of the dhalang (see figures 3 and 4; in figure 4, please note a comedian, Ranto Edi Gudel, the composer of "Anoman Obong," sitting in front of the row of pesindhens), rather than, as was common before, in the gamelan. ${ }^{91}$ This practice, which too has gradually spread and become standard, makes the singers more visible and sets them apart from the other musicians. Moreover, Nartosabdho also had "not only one or two pesindhens, as it was common with other dhalangs, but at least four, each of whom had a high reputation in her area." 92 Nartosabdho's emphasis on the singers was a part of a larger trend, pointed out to me by Pak Naryo: the tendency to make music, especially non-dramatic music, more and more central to the performance. Another practice developed by Nartosabdho that has since become common is to allow the audience to request a song by sending a letter to the dhalang.

\footnotetext{
90 For the development of limbukan, see Suratno et. al., Limbukan. Suratno (pp. 37-38) endorses findings by Nartosabdho's biographer Sumanto that today's limbukan is the "Nartosabdho model." See Sumanto, Nartosabdo, p. 82.

91 Sumanto, Nartosabdo, pp. 89-90.

92 Ibid.
} 


\section{Jan Mrázek}

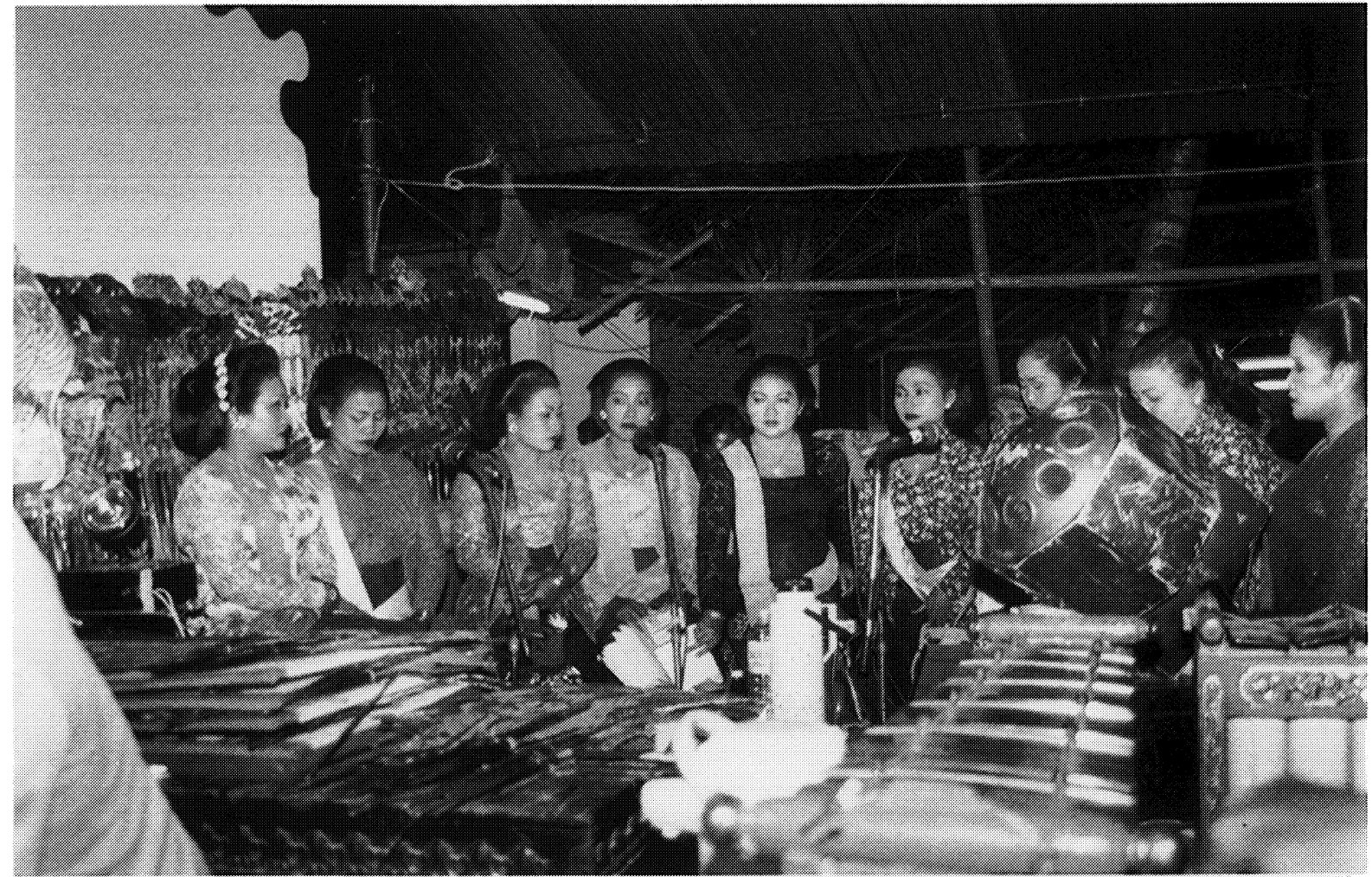

Figure 3

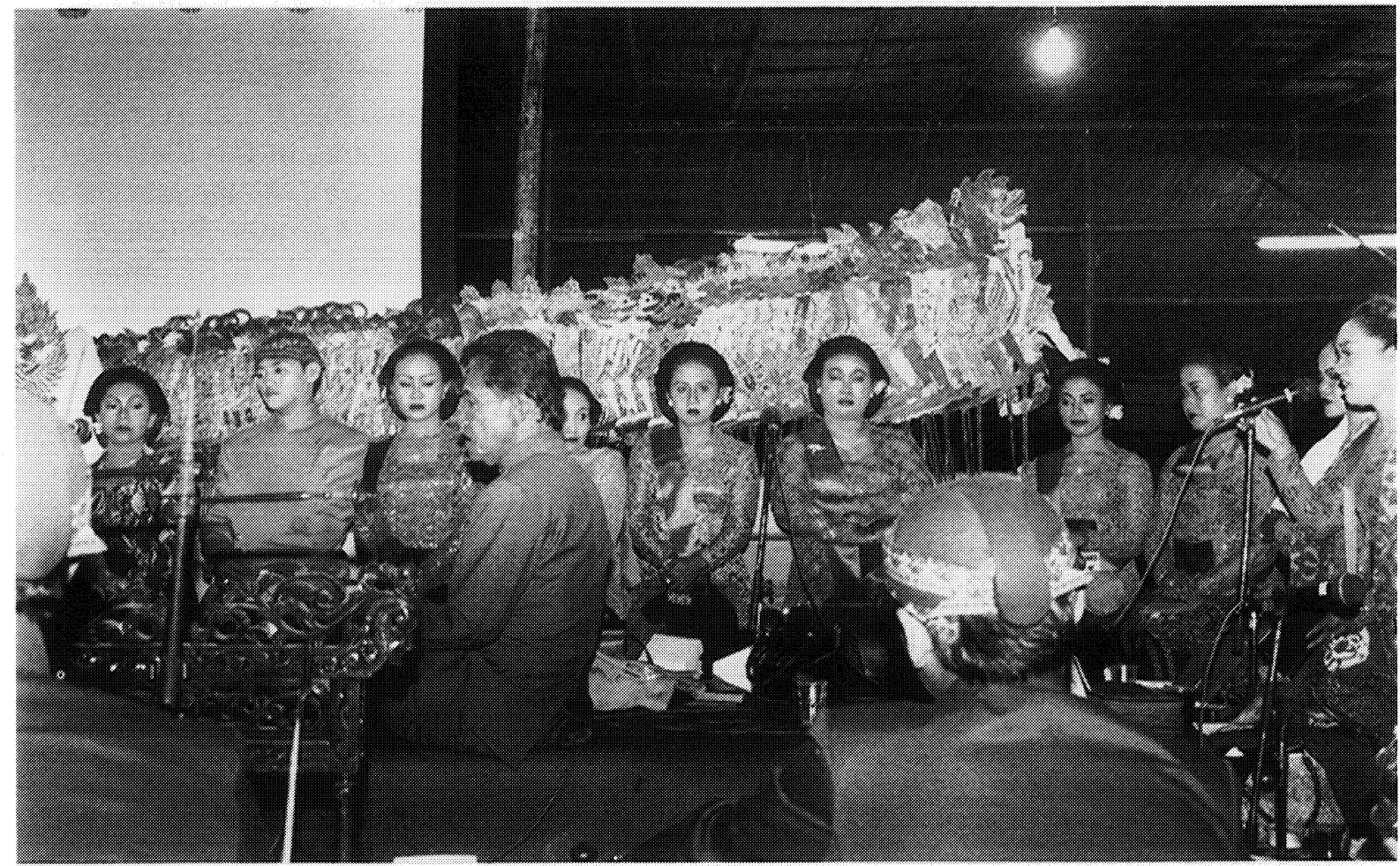

Figure 4 
According to Pak Naryo, this was first done during Nartosabdho's performances broadcast on the radio, and it imitated various popular radio programs in which the audience or the radio listeners could request a song or gamelan composition by letter. Of significance here is the fact that this practice established communication between the dhalang, the listeners, and the singers. Much of the same thing is happening today, except that the exchange is more explicit: the dhalang reads the letter aloud and often displays it on the screen, he addresses the singer by name, and talks to her before she sings. The development of this practice-the beginnings of a dialogue between the dhalang and the singers-which relates directly to the increasing prominence of the singers, is extremely important, and I suggest that it contributed to later developments being studied here, such as the use of comedians who engage the dhalang in a dialogue and the general alteration in the character of the dhalang's function.

However, before we examine the further developments, let us look at the possible sources of these phenomena in wayang (the growing importance of singers and nondramatic music generally, especially "songs," as well as the beginnings of the dhalang talking to other people). I would like to do it again by looking at Nartosabdho's biography. I have already suggested in my notes on Nartosabdho's compositions that the "song-ness" of his songs can be traced not only to his interest and work with the more or less traditional lagu dolanan, but also to influences from his own youth, when he sang and played the violin and guitar as part of a kroncong group. Practically all Nartosabdho's own compositions are songs-they have prominent vocal parts, and in most cases the gamelan functions as an accompaniment-and they require singers. In other words, Nartosabdho's own compositions make singers prominent. Apart from his own compositions, he has also composed prominent vocal parts to existing gamelan pieces, and these, too, were often included in the clown scenes, as well as in other parts of the performance. Also, Nartosabdho included langgam Jawa/kroncong songs, accompanied by gamelan, in the clown scenes, which again brought the singer into prominence.

What happens to the dhalang, and to the relationship between the singer and the dhalang, when the singer sings a song? Everybody listens to, and looks at, the singer, and the dhalang takes a break-somewhat like when two comedians talk and the dhalang only listens. When I asked Pak Sutino to define the basic difference between performances today and in the past, he said that in the past only the dhalang was speaking, and when there was no pesindhen, the dhalang, in the clown scene, would sing the light gamelan songs (dolanan) himself, but singing in the voice of one of the characters, one of the clowns. Today, it is only the pesindhen who is singing, in her own voice, and the puppets, too, take a break. We should ask about the possible sources of the dhalang's new habit of "taking a break" and letting someone else, another star, become the center of attention.

An important fact that must be considered when discussing Nartosabdho is that, unlike most dhalangs at that time, he did not emerge from a dhalang family; rather his father was a gamelan musician, and for a good part of his life Nartosabdho followed his father's profession. Born in 1925, Nartosabdho began to perform as a wayang kulit dhalang only in the late 1950s, and became famous as a dhalang only in the late 1960s. Before he became a dhalang, he had worked as a gamelan drum player, so that he had responsibility for directing the music, in various kethoprak groups, and later in the 
wayang orang group Ngesti Pandhawa. After a number of years as drum player and music director in the wayang orang group (wayang orang is a wayang in which people, rather than puppets, represent the characters), he was occasionally entrusted to perform as the dhalang in wayang orang. His success in these ventures led him to consider becoming a dhalang in wayang kulit.

How did his involvement in kethoprak and wayang orang groups (as a musician), and his experience as a dhalang in wayang orang, contribute to his innovations in wayang kulit? This has to do with the character of the theatrical genres. In kethoprak, there is no dhalang, only a director with limited powers, and the actors are not puppets. In wayang orang, the dhalang's function is much less important than in wayang kulit, for he sings the mood songs, narrates, and participates in directing the music, but the actors in wayang orang speak their own parts and dance, and when they claim the center of attention, the dhalang, though he has to remain alert, takes a break-he merely listens and waits for his turn. When the clowns come out, for instance, he takes break in very much the same way that today-years after Nartosabdho's death-the dhalang in wayang kulit makes way for the comedians. I am suggesting this: when Nartosabdho became a dhalang of wayang kulit, and gave up some of the dhalang's centrality to other performers, specifically to the singers, when he moved them near the screen, made them visible, and gave them greater roles in the performance, he was inspired by kethoprak and wayang orang, and his experiences as a musician. He consciously or unconsciously brought his conceptions of dramatic performance from his past into his new profession.

It is not important for our purposes to establish whether Nartosabdho was the first dhalang (in the Solonese tradition) who talked to the pesindhen during the clown scene, but it is likely that he was (here we would profit from further research). In any case, on his recordings from the seventies and the early eighties, he leads extended comic dialogues with the pesindhen; and he also explicitly directs the singers, male and female (e.g., "now without gamelan: the men sing this part, the women this part"), thus elaborating in another way on the musical dialogue; and on his later recordings, he asks the audience for applause for the singers ("tepuk tangan!").93 All these practices, probably initiated by Nartosabdho, are common today, and they are the direct antecedents of the later developments that go further, such as the participation of one or more comedians. In performances today, the comedian or comedians, as well as other guest stars, typically sit(s) next to the pesindhens, near the screen, on the dhalang's right.

Long before Nartosabdho became known as a dhalang of wayang kulit, he was already famous as a composer and musician; when President Sukarno had dancers from the wayang orang group perform in the palace, he specifically asked that Nartosabdho [then Soenartol play the drum. Before the Ngesthi Pandhowo wayang orang performances, Nartosabdho's compositions were performed, with Nartosabdho himself playing the drums, and his compositions were broadcast on the radio station, RRI Jakarta. ${ }^{94}$ Nartosabdho's long career as a musician and composer of songs before he became a dhalang obviously helps explain why he gave such prominence to music

93 See Ki Nartosabdho, dhalang, Pendawa Nugraha, sound recording (Pusaka Cassette), tape 5.

${ }^{94}$ Sumanto, Nartosabdo, pp. 48-49. 
when he became a dhalang, and this practice has become standard in today's performances. Nartosabdho organized a professional gamelan group, Condhong Raos, with the best musicians he could find-a few from the group Ngripto Raras, in which most of the musicians were dhalangs, and a few who were members of radio station gamelan groups in Solo and Semarang-and he paid them almost twice as much as other dhalangs. ${ }^{95}$ Top dhalangs today, too, are accompanied by large gamelan groups with carefully selected musicians, and they pay them-especially the more important ones-wages more than double the typical wages of village musicians. The existence of permanent groups of musicians is necessary for-and makes possible-satisfactory performance of pieces not in the traditional gamelan repertory, and their various arrangements. Pak Naryo frequently commented that in the past "wayang was wayang," there were only a few musicians, and the dhalang was the absolute center, while today "only music is made important"; we recall that Pak Naryo also noted there were typically only about ten to twelve musicians in wayang in the past, while today there are often more than fifty. Raden Mas Sayid writes that "the form of wayang performance has become a concert of light-hearted music [klenengan gobyog]." 96 It is important to remember that this increasing importance of music is inextricably connected to the changing powers of the dhalang, to the appearance of other stars, and to the new practice that allows a dhalang to take a break while others perform.

In sum: the changing role of the dhalang and his changing authority, which is today most strikingly manifested in the dhalang being at times merely one of the performers involved in a conversation, only one of the stars, who occasionally "takes a break" and gives the stage to other stars, a general situation that vitiates the connection between the dhalang and the puppets, is directly connected to the rising prominence of music, especially songs, and with it the increasing prominence of singers, especially miked singers. This is also a matter of the attenuation, or occasional elimination, of the organic bond between the puppet and the puppeteer that, as I have shown in another discussion, is central to the wayang performance. Moreover, I have suggested that this is best understood not as only an exclusively internal development, but as a matter of interaction of wayang with radio, kroncong, kethoprak, and wayang orang.

This interaction is a matter of opening to the other musical and theatrical genres, to the foreign (the not-wayang-kulit), and it is the same process that we have noted in our discussions of music in the clown scenes and the incorporation of foreign elements into the music. These connections can be seen in the following example. We remember that Nartosabdho and later many other top dhalangs incorporated into their performances elements from various kinds of foreign music; what's more, they incorporated not only the music but also musicians-pop singers, keyboard and drum set players, as well as singers and musicians from various parts of Java. In a number of Nartosabdho's recorded performances, the dhalang has a longish comic conversation with a singer (pesindhen) from Banyumas, and then asks her to sing a song or two from Banyumas. ${ }^{97}$ The singer, as well as the dhalang, speaks in the Banyumas dialect of Javanese, which is easily understandable to speakers of other Javanese dialects, but is different enough

95 Ibid., pp. 63-64, 66, 68-69.

96 R. M. Sayid, “Hubungan antara wayang dan Penanggap," Gatra 14, 1987, p. 6.

97 See, for instance, Ki Nartosabdho, dhalang, Banjaran Bisma, sound recording (Kusuma Recording KWK039), tape 5, side B; or Ki Nartosabdho, dhalang, Pendawa Nugraha, referred to above. 
to sound funny to them..$^{98}$ At this moment in the clown scene, the two kinds of opening - opening to foreign musical and lingual elements; and opening to not-wayangness (since a conversation between the dhalang and another person is a structural element foreign to wayang)-combine or are merely two aspects of the opening to the foreign. In either case, this act of opening, and the interaction with the foreign, has not merely left a trace on the performance, but rather is present in the performance. In the case of the music, the different musical idioms coexist and remain audible, rather than disappearing into the structure. Similarly, the process of opening to other theatrical genres, such as kethoprak, is not merely a matter of history, for the foreign element remains present in the structure, and is even displayed, as a manifestation of the opening to something foreign, of an interaction. For instance, when the dhalang begins to talk to a pesindhen or to a comedian, it is not enough to say that this practice may have originated in the interaction of wayang with other genres; we have to see that at the very moment when the conversation takes place, when the dhalang speaks as just another person on the stage rather than as the dhalang, the opening, and the interaction, "happens." Something of kethoprak takes place at that moment, in the same way that when the keyboard plays together with gamelan, the act of innovation and interaction can be heard "here and now."

Similarly, the connection between the importance of music on the one hand, and the decline of the dhalang's sovereignty (which is now most clearly manifested in the presence of comedians) on the other, is a matter of the present, and is apparent in present performances. Whether a singer sings a song or two comedians talk, the dhalang takes a break. As I mentioned, the comedians generally sit next to the pesindhens; and they interact with the dhalang and function in the clown scenes very much like the singers; and as the singers often become comedians for a moment, so the comedians sing songs (and female comedians especially double as pesindhens). ${ }^{99}$

Let us now return to the more radical innovations in the clown scenes as they are performed currently, and see how many of the tendencies discussed above are developed. One of the major phenomena is, as I have signaled earlier, the emergence of guest stars. I have sketched the history of this phenomenon, and now I would like to look more carefully at who they are and how they function in the performance.

I focus first on famous dhalangs and large-scale performances, because they are imitated by less well-known performers. Let us first look at where the guest stars come from. In general, they come from other genres and other media. There are a number of famous comedians whose major occupation is appearing in wayang performances with the top dhalangs. Ranto Edi Gudel (Ranto Edi "Water-Buffalo-Calf"), a kethoprak actor and composer of the multi-genre song "Anoman Obong," discussed above, is one of

\footnotetext{
98 In a newer version, Sutami, a pesindhen who can sing both traditional pesindhen parts and langgam Jawa songs, and had spent with her husband, Suratno, some time in America, has accompanied Warsena Slenk (until 1996) and more recently (1997) another young dhalang, Sutomo Tomopandhoyo, and in their performances, both dhalangs have made it a habit to ask her to say something in English during the clown scenes.

99 Regarding the affinity between singers and comedians in wayang performances, it is interesting to note that according to one source, in the middle of the nineteenth century, a palace clown who performed as a dhalang is said to have introduced a female singer into his wayang performance at the Solonese palace. Marc Perlman, personal communication.
} 
the most popular, and he frequently appears with all the most famous dhalangs: Anom, Manteb, Warsena Slenk, Crazy Djoko, and Enthus Susmono. Yati Pesek (Yati "Flatnose"), whose nose is indeed "incredibly flat," 100 is originally from Yogya, but she is also very popular and performs with the top Solonese dhalangs. She, too, is a kethoprak actor. (By the way, she is the singer on some of Manthous's Campursari cassettes.) Marwoto and Gito are two kethoprak actors, popular especially in Yogya, and they frequently perform with popular Yogyanese dhalangs (such as Seno Nugroho), but occasionally with other dhalangs as well. Gito also occasionally performs as a dhalang in wayang kulit. Another clown, popular especially at the largest spectacular performances, is Bagyo, the actor who has played Gareng, one of the clowns, in the Ngesthi Pandhawa wayang orang group in Semarang, the same wayang orang group with which Nartosabdho was associated; he always wears the mask-like makeup and dress of Gareng from wayang orang. On some occasions, there are guest stars from other genres, such as Jujuk from Sri Mulat, or the very popular Kirun, who used to be a singer in Anom's wayang-gamelan group but later became a kethoprak actor, and who finally has become a leader of a popular comedy group (Kirun cs) appearing regularly on TV, while at the same time he keeps up his involvement with kethoprak (Ketoprak Kirun cs). ${ }^{101}$ The simple point about these people is this: if I have suggested that Nartosabdho's songs and dialogues with the pesindhen were inspired by his experiences in kethoprak and wayang orang, and his innovations led to increased participation by comedians, we see now that, after Nartosabdho's death, not only are stage practices reminiscent of kethoprak and wayang orang invading and being absorbed by wayang kulit performances, but so are kethoprak and wayang orang performers becoming more and more involved. What were first merely functions or "roles" borrowed from kethoprak and wayang orang and performed by the pesindhen and the dhalang (not the roles in the sense of specific characters, but rather as functional elements of particular kinds of theatrical interaction), are now being "filled in" by kethoprak and wayang orang actors, so that the not-wayang-kulit character of the "roles" and of such interaction is made more explicit (most obviously in the case of the actor playing Gareng in wayang orang costume). Thus, what is happening on the stage, who acts, and how the actors interact, is affected by wayang's opening to the interaction with other genres. The dhalang is becoming a little less like a wayang kulit dhalang, and a little more like a wayang orang dhalang, or like an actor in kethoprak: he is becoming one of the actors. (Figure 5 shows, standing from left to right, Yati Flatnose from kethoprak, Bagyo/Gareng from wayang orang, Manthous, and Marwoto from kethoprak, at a 1997 two-screen wayang kulit performance.)

\footnotetext{
100 I borrow this expression from Gogol's "Nose."

101 See "Kirun Pilih Tinggal di Desa," Suara Merdeka, October 23, 1997.
} 


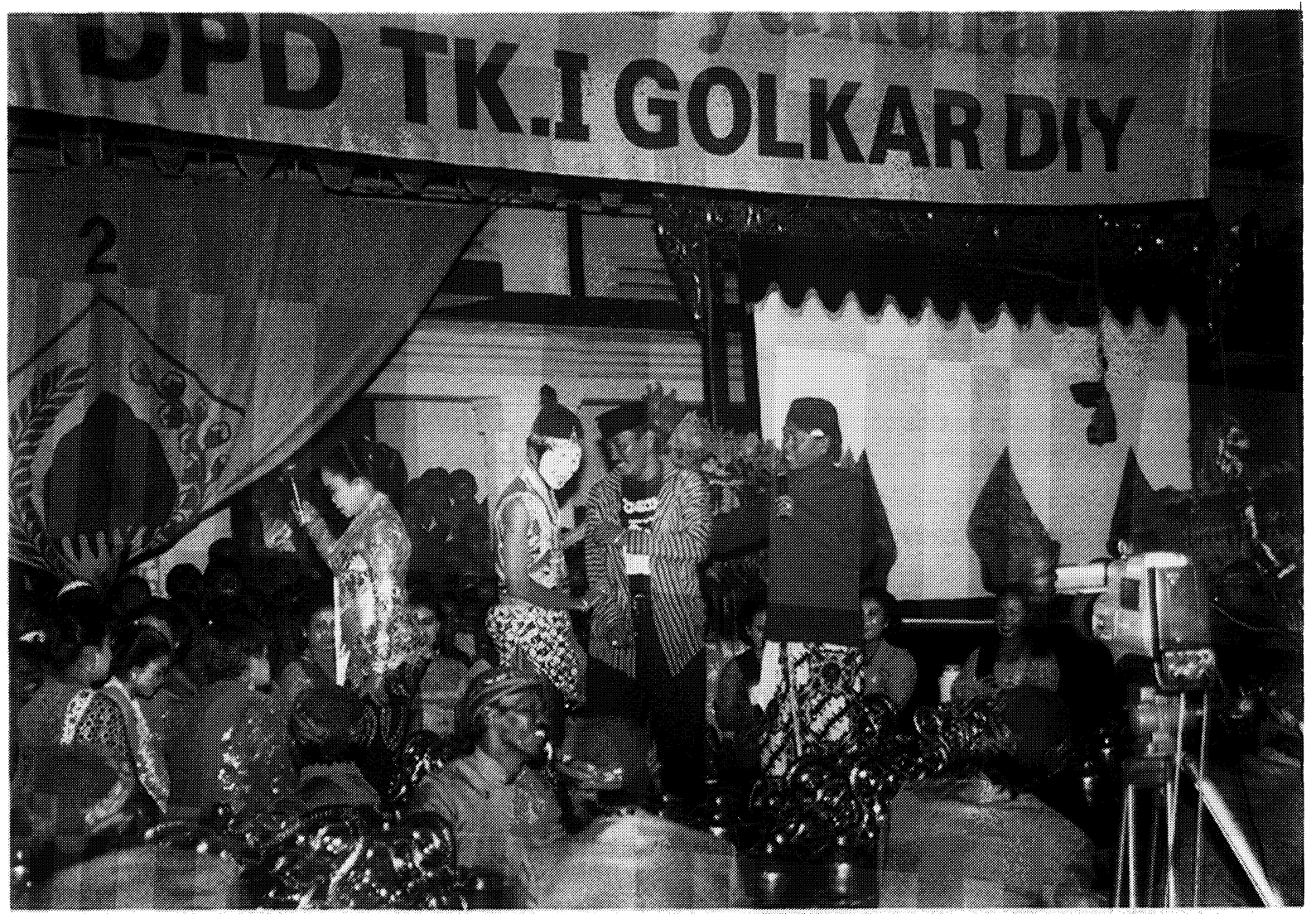

Figure 5

The singers, too, are coming from other genres, as I mentioned in my observations on the mixing of music: pop singers, rock singers, dangdut singers, kroncong singers, jaipong singers/dancers, and so on are all getting involved. ${ }^{102}$ Moreover, there are new standards for pesindhens today: not only do they have to be good pesindhens, but they are also asked to sing langgam Jawa/kroncong songs. Some excellent pesindhens may have difficulty finding a job because they cannot sing langgam Jawa, and one hears bitter complaints from senior pesindhens about the local rock star, still in high school, who performs only a few songs in wayang and gets (I am thinking about a particular case) about five times as much compensation as an experienced pesindhen who sings

102 Of the singers, pesindhens are most "at home" in wayang, but it is interesting to remember that in the recent past they were radically less prominent in wayang performances, so that they too can be perceived as "newcomers" in their new function. Also, as we look into a more distant past, there were probably no pesindhens in wayang. In any case, in many areas, as one dhalang, Pak Sutino, pointed out when I asked him about wayang and pesindhens in the past, the major traditional competitor of wayang was tayuban, a danceparty in which a professional female dancer-singer sings and dances with male guests. The pesindhen as she/he currently functions in gamelan is believed to have evolved from the tayuban dancer-singer. See Sutton, "Who is the pesindhen ?" This would mean that the pesindhen might have come into wayang from tayuban, which was the other major genre at that time, in a similar way that today kethoprak actors or kroncong singers come to wayang from "other genres." Later, wayang's interaction with another entertainment medium, the radio, contributed to the pesindhen's prominence. 
during much of the all-night performance. On the other hand, those pesindhens who can adjust are building their popularity on their versatility. A case in point is the beautiful Anik Sunyahni, originally an accomplished pesindhen, who has been recording langgam Jawa, has appeared in soap operas on TV, has been the guest star on one of Manthous's Campursari cassette, and appears as a frequent guest star at wayang kulit performances. (According to the gossip, she is paid exorbitant fees-five millions rupiah [about US $\$ 2,300$ in 1996] per performance, not much less than a famous dhalang, much more than twice the total fee of a decent village dhalang and his whole group, and almost hundred times more than a pesindhen in a village performance-but we will return to gossip later.) Just as the introduction of more prominent comedians into a performance alters the respective roles of many of the participants, including notably the dhalang, so the introduction of other types of singers influences the role of the pesindhens, who must adapt-they must become also langgam Jawa/kroncong singers.

In addition to singers, there are now often dancers presenting brief dances as a part of the clown scene. These are most commonly non-Central Javanese dances: the East Javanese ngremo, or the West Javanese jaipongan are most popular, as are dances to Banyumas music (Figure 6; in many cases, the person who originates from a particular area sings and dances in his or her own regional style). This can be seen as an direct extension of including East or West Javanese music, which is commonly done, as I have mentioned above, and it is another example of the bringing in of genres other than wayang kulit.

I have described how the different guest stars come from different other genres and other regions, and they are all various manifestations of foreign elements brought into the clown scene. It is important to see that they have not merely "happened" to come from kethoprak, wayang orang, East Java, kroncong, or other foreign territory; rather they are explicitly presented as coming from other genres or areas, or as being the manifestation of something foreign, in the same way that foreign musical elements are not "quietly" incorporated, but rather presented as foreign, for the quality of foreignness is appealing. And if they are not actually foreign or even markedly foreign, their exotic qualities will be exaggerated in performance. For instance, one of the most favorite guest stars in Crazy Joko's performances is the londo- "the Dutch" (which is the general term for white foreigners). She is actually of mixed blood and has never been outside Indonesia, but in performance she is dressed, made up, and introduced as the foreigner, or rather like an exaggeration of the foreigner (see Figure 7).

The phenomenon of the "guest star" itself is foreign to wayang. The presence of guest stars changes essentially what happens on the stage, and what happens to the dhalang and to the puppets-I have discussed that. But we should also note that this foreignness is explicitly displayed, made more apparent, and appreciated. In wayang, the "guest stars" are introduced as bintang tamu-which is not a Javanese phrase, but Indonesian, strongly associated with Indonesian (rather than Javanese) popular culture: pop music concerts, variety shows, TV programs, and so forth. Using the term bintang tamu in wayang evokes these forms of entertainment, and frames the guest stars as additionally foreign: as Indonesian rather than Javanese, and as modern. 


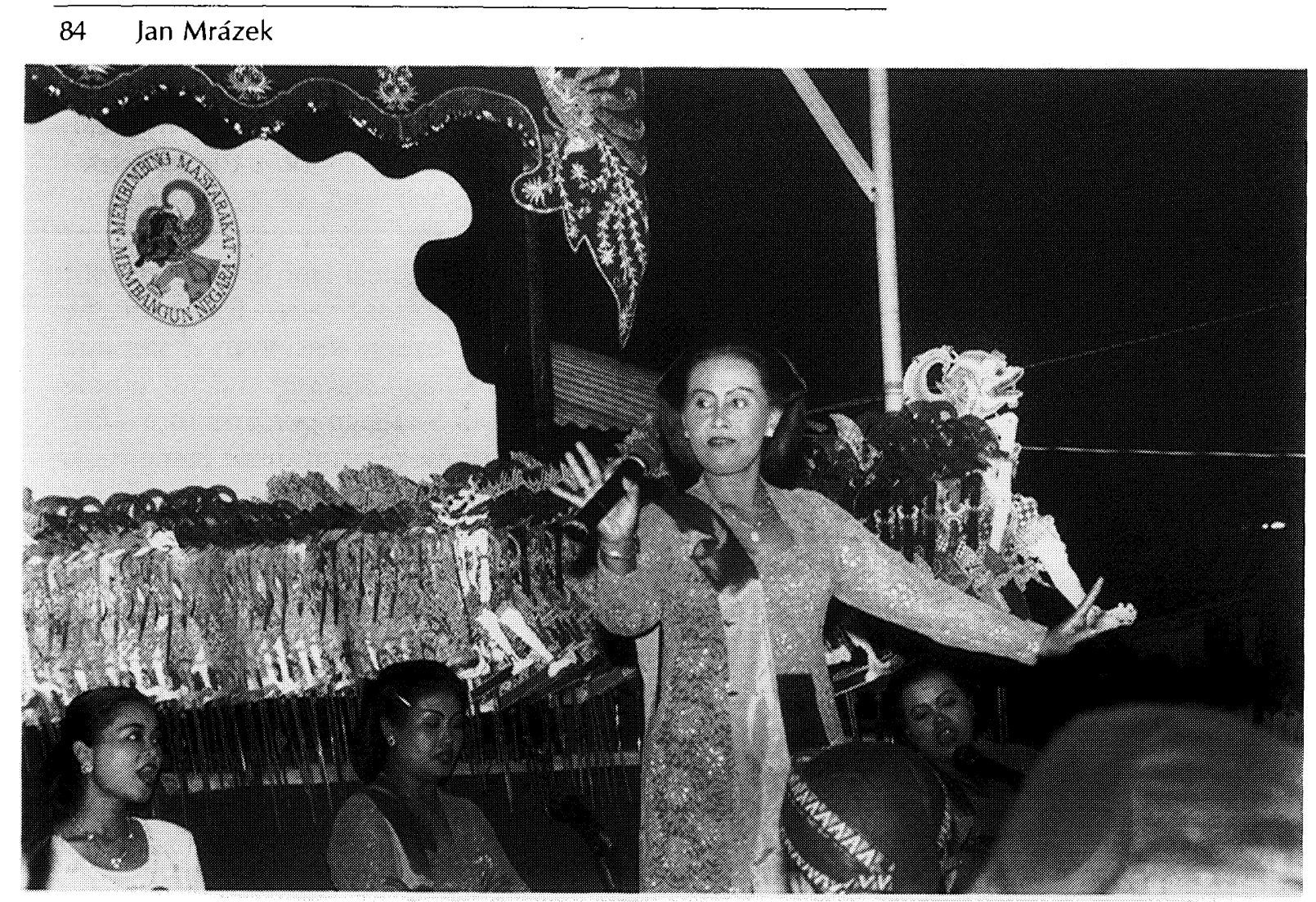

Figure 6

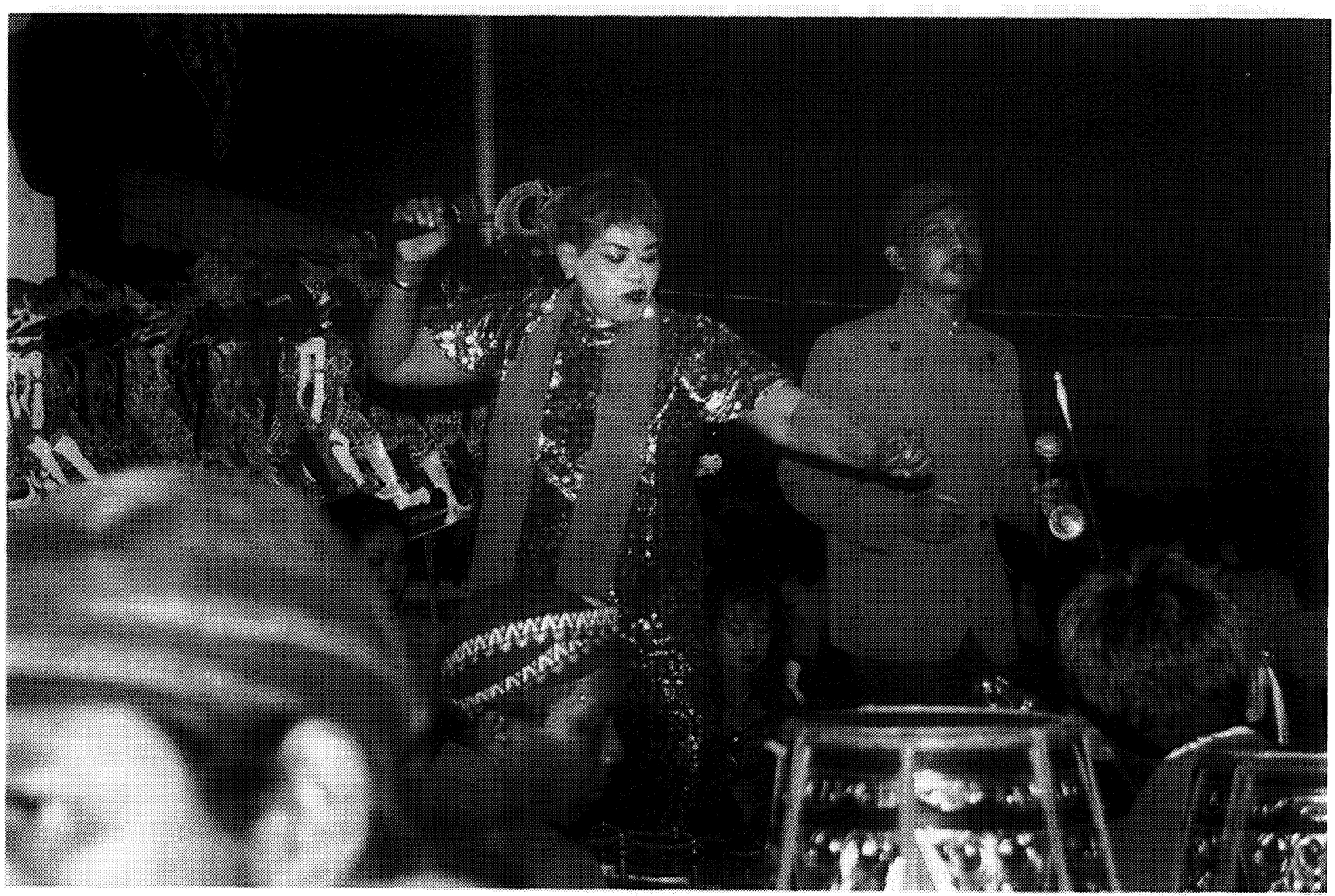

Figure 7 
There are two kinds of guest stars. First, there are those guests stars who are invited by the sponsor and who therefore perform with various dhalangs. Secondly, there is another interesting group of guest stars: they are guest stars for the sake of being guest stars, but they are really permanent members of the dhalang's group, appearing in all performances with a particular dhalang (this is true both about singers, especially pop music and rock singers, and comedians, including the "Dutchwoman" mentioned above). They are "guests" only in the sense that they are foreign to the wayang performance, and they are presented as such because it is trendy to have guest stars. They are regular features, "permanent residents," in the wayang performance of a particular dhalang, and are not "naturalized" because their foreignness is desirable. We might call them the permanent-resident stars, or, to use the official term for permanent residents: resident aliens.

The growing importance of the guest stars, and their nurtured foreignness, affects the working relationship between the performers and the sponsor, and relationships among the performers. Even in the past, and today in more traditional performances, the sponsor might ask, for instance, for the inclusion of pelog gamelan in addition to the standard slendro, or he might ask for one or more pesindhens: as with other developments, one can find antecedents, and one can see the present innovations merely as "further" developments. The present development is nonetheless very radical. The guest stars-especially famous non-resident guest stars (whose foreignness is imitated by the resident guest stars) - have substantial autonomy. They are not puppets, they "have their say." The particular configuration of guest starsand that relates to the configuration of attractions, which may be any combination of kethoprak, wayang orang, jaipongan, kroncong, dangdut, rock ... -is generally selected by the sponsor, and the dhalang politely agrees. (When he does not find it acceptable, he is likely to lose or give up the engagement, as in the case of Manteb, who gave up his performances on TV because the sponsors were granting too much attention to the guest stars and in other ways further restricting the powers of the dhalang; other, younger dhalangs took up the job he quit.) It is the sponsor who decides on the ingredients of the gado-gado, the "mixed salad," and the dhalang has to mix them. Thus, not only on the stage, but also in his relationship to the sponsor, the dhalang finds that he is now only one among several performers, though he still has special powers. The performers' relations to the sponsor affect the relations among the performers: the guest stars are now the dhalang's more or less equal collaborators, different, for instance, from the gamelan musicians, who merely support him. Like in traditional wayang, the working relationships among the performers "off stage," the ways that the performers work together, are projected "on stage": as I have discussed earlier, on the stage too the dhalang is becoming merely one among the stars, only one among those speaking into a microphone, and the sponsor's initiative is becoming more visible, more explicit in the way he manipulates the details of the event. Traditionally, the sponsor's initiative consists in deciding to sponsor the event and spending an amount of money on it, but the particulars of event and performance are to be executed in accordance with tradition, rather than in accord with the whim of the sponsor. 
Another major development related to this has to do with the new ways in which the sponsor, the guests, and the uninvited spectators participate in the performance. In this context, we note again the letters with requests for songs from the audience. The point here is not simply to request a song, but to become part of what is happening on stage, for the person who asks for the song always writes his name, and he typically "sends" the song to somebody, usually to one of the guests, who may be a friend or perhaps a local official, or he may send the song to the sponsor or even the dhalang. The letter often specifies who should sing the requested song, whether it be one of the female or male singers or one of the guest stars. The dhalang reads the letter and usually acknowledges the gift accompanying it: a pack or two of cigarettes, or an amount of money. Thus, these requests bring onto the stage, in name at least, the requester as well as the person to whom the song is sent; they also mark the importance of the singer and of the person who offers payment for the song, who thereby sponsors, in effect, a small (music) performance within the (wayang) performance and gains an opportunity to "show off." This practice has been common in wayang for some time, and its introduction is generally ascribed to Nartosabdho, specifically to his performances at the various radio stations; the practice is clearly an imitation of the popular "Listener's Request" programs that presented various kinds of pop music and Javanese gamelan. In many performances the practice still retains its affinity to radio: the person to whom the song is sent does not need to be present at the performance, but is meant to listen to it on the radio (even when this is not a live broadcast); for instance, in one performance by Anom, a guest sent a song to Anom's younger brother, "Mas Slenk in Pajang." The radio stations promote this practice, thus asserting their presence, as well as the presence of radio-broadcasting. At one performance, for instance, the technicians from the radio station recording the performance sent a song to the technicians of another radio station. (The dhalang commented that the performance was a communication between radios [antar-radio].) We see here, by the way, a nice example of wayang collaborating with another medium. Ironically, this practice is a major attraction of live performance. For instance, one wayang spectator told me that the main reason he prefers watching a live wayang performance to watching wayang on television is because in live performances he can request songs.

While continuing in the form described above, at the same time the practice of delivering and accepting song-requests has developed further in recent years. Occasionally the requester now specifies a singer who is not one of the performers: very often he names himself (and occasionally herself), one of the guests, or even the sponsor. The person named is asked to come on or to the stage, is given a microphone, usually has an interchange with the dhalang, similar to the dhalang's dialogue with the pesindhen, and then sings. When he or she is a bad singer, everybody laughs, which the singer takes in good humor; when the singer is good, people listen carefully, critically, and enjoy the singing. Both bad and good singers appear. The standards are high, and some of the singers are excellent. In some cases, the singer sings his own composition, or more commonly, new lyrics in traditional poetic and musical form (macapat). At other times, a guest or the sponsor distributes photocopies of new lyrics to be sung by the performers and the guests; often, these are lyrics for simple and well-known melodies, such as the gerongan (male chorus part) in Subakastawa. 
These practices have one thing in common: they are motivated by the wish on the part of the audience to appear in performance, at least in name, to affect the performance by sponsoring the song, or, preferably, to join the performance by singing and talking to the dhalang. Often, it is apparent that the volunteers want to talk more than the dhalang would like them to, which at times results in an embarrassing situation. As more people come on the stage and more people talk into the microphone, the dhalang now becomes even more only a coordinator of other actors, of other people, as he reads their letters, talks to them, listens to them, listens to the song that they have requested, and reads more letters. The dhalang sometimes refers to the "singing spectators" as guest stars, half in joke-and, from his point of view, they are very much like that.

In this context, we note the influence of another kind of entertainment: karaoke parties. At karaoke parties members of the audience alternate in singing into a microphone accompanied by recorded music. Karaoke is extremely popular in Indonesia. Many restaurants where people hold celebrations provide facilities for karaoke, some people own karaoke tape players and have karaoke parties, and karaoke has become a popular entertainment at ritual celebrations. Thus, it is one of the entertainments competing with wayang. In the season for celebrations, there might be a karaoke party at one house, and wayang at another. Wayang performances and karaoke parties are together in the same world, they interact with each other, and people who enjoy karaoke, and enjoy taking turns singing (into a microphone)-and so many people do-are likely to enjoy a similar kind of entertainment in wayang performances. These preferences, in turn, motivate the dhalang and the sponsor to provide opportunities for this kind of audience participation.

This leads us to another aspect of the opening up of the clown scenes, one that is frequently discussed by Javanese commentators: wayang's accommodation to the demands of the audience. The audience is becoming more assertive; the innovations, it is said, are there because the audience demands them. The expansion of the clown scenes, the development of the second clown scene (limbukan), and the radical developments within them, are said to be responses to "the demand of the times, or more specifically, the demand of the audience in these times." 103 Interestingly for our purposes here, the wayang's responsiveness to what the audience likes, opening of the performance to the times, is often perceived as a sign of the dhalang's lack of authority, a lack of control over the performance. Even Manteb, a top dhalang who has introduced and popularized many innovations, says:

It is a great mistake if young dhalangs say as an excuse that they follow the audience. Because it is precisely the audience that can be controlled/managed [dikendalikan, from kendali, "reins"], and they would also have the same perception of the performance [as the dhalang] if they were presented with a performance that has its basis. ${ }^{104}$

Here wayang's accommodation of the wishes of the audience is interpreted as another symptom of the dhalang's decreasing authority-it is yet more people interfering with

103 "Limbukan Pun Diprotes," Kedaulatan Rakyat, September 7, 1996.

104 Ki Manteb Soedharsono, quoted in Joko Dwi Hastanto, "Dari Sarasehan Wayang: Menggugat Kreativitas Dalang," Suara Merdeka, October 12, 1996. 
his sovereignty-and, as it is often termed, of the performance "breaking down" (rusak). At the same time, clearly this responsiveness gains the dhalang popularity, and thus another kind of power, and keeps wayang alive, though living a different kind of life.

We will return to this central issue, which is directly related to the guest stars, audience participation, and the dhalang's compromised sovereignty, but first we must look at another aspect of the clown scenes and the way they have developed: the space.

The screen and its decoration is "made to size" to the dhalang's body. The screen and its center, where the dhalang sits, is made prominent by the single lamp and the symmetrical decoration. The centrality of the screen and the dhalang is further articulated by the placement of the screen within the architecture, and the architecture of the screen is unified with the architecture of the house or temporary structure. ${ }^{105}$ What happens spatially in a contemporary clown scene? I have mentioned that Nartosabdho has moved the pesindhen from inside the gamelan to a prominent place near the screen, at the dhalang's right, near the light, and this seating arrangement is universally followed today. Today, the pesindhens either face the dhalang, or, with their backs to the screen, they face the audience, or they manage something in between (see Figures 3 and 4, p. 76). When the dhalang engages the pesindhen in a dialogue, she becomes the other center of attention (I am here thinking in spatial terms): the dhalang and the central space of the screen no longer constitute the only center on the stage. It must be kept in mind that the pesindhen is not merely a "source of sound," but also a commanding vision; she wears an impressive dress, heavy, almost mask-like make up, a large hair-do, and she has "a golden voice plus [plus] attractive face in addition to sensual physical appearance." 106 This quotation is from an article on innovation and describes what is today important. The pesindhen's refined sensuality was probably always significant, if indeed she evolved from the dancer-singer, and moving her into a prominent place and then increasing the number of pesindhens on stage makes her visual-physical presence more important specifically in wayang. Her singing, her dialogue with the dhalang, her command of the microphone as tool and symbol, call attention to her situation as the second spatial center. Moreover, the dialogue also enforces her visual-physical presence with more or less subtle references to her body. For instance, Sutomo Tomopandhoyo has a pesindhen from the Boyolali area, which is the center of milk production. In performances, he asks her her name and where she is from (as is common in such dialogues), and when she answers that she is from Boyolali, the dhalang asks her what is Boyolali famous for, and she answers that it is famous for its susu. Susu means milk, but it also means female breasts, and thus the pesindhen is heard saying that she is from an area that is famous for female breasts (kondhang susune), in response to which the dhalang says something to the effect, "Oh, is that so?" and looks at the pesindhen; or one of the clowns on the screen repeats, screaming out, unable to control himself: "Kondhang susune, kondhang susune!" ("Famous for her breasts, famous for her breasts!" though it also means "Famous for its milk.") This kind of reference to the pesindhen's body is certain to make everyone look at her, and even those who might later object to indecency in the performance

105 See Mrázek, "Phenomenology of a Puppet Theater," Chapters Two and Seven.

106 "Inovasi Semakin Jelas," Kedaulatan Rakyat, September 7, 1996. 
would look to check whether the words corresponded to reality. This does not mean that the pesindhen's physical attractiveness is merely an invitation for bawdy remarks. The row of festively dressed and made-up pesindhens near the screen makes the show more spectacular, and these handsome pesindhens are becoming central in the performance space.

This innovation had led to others. For instance, the area where the pesindhens sit today has expanded and gradually developed into an empty stage that gives the comedians, singers, and other performers a place where they can stand up and perform. (In those performances or parts of performances when they are not standing up, they sit near the pesindhens.) The leading innovators in this respect, such as Crazy Djoko and Enthus Susmono, use a significantly large area for the stage; in smaller village performances that imitate the large-scale events, the comedians and singers stand somewhere near the pesindhen, whether or not there is much space (the particular setup is different every time). (Figure 8 shows a performance by Crazy Djoko, sponsored by the police, in which three dancing pop singers are joined by two local off-duty policemen; Figure 9 shows a village performance with less stage-space, with a pop singer standing close to the sitting pesindhens, another pop singer, and a male transvestite comedian dressed as a pesindhen; also see Figure 7, p. 84.) This is a major development, because the newly developed stage with people standing and dancing on it becomes much more prominent than the dhalang's place; it becomes the unrivaled focus of attention. The dhalang is "off stage" then. Or, one could say, the dhalang was, in a complex way, off stage, or both on and off stage, but now there is a "real" stage, and he is off.

How do people move in these altered spaces? It is very common today for the guest stars to stand up when it is "their turn"; more rarely, the dhalang himself stands up and dances or boxes with the puppets (of the top dhalangs, only Enthus regularly stands up; most never do, and some, such as Crazy Djoko, only rarely). This act of standing is a radical innovation, and criticism of it is very strong. Critics argue that standing up breaks the rules of the etiquette (tatakrama) and is impolite (ora sopan). This has to be understood in the context of the proper Javanese way of moving in space. As on the wayang screen, to be higher in space means to claim higher status. ${ }^{107}$ When there is a more or less formal gathering in which people sit on the ground, it is sometimes very impolite to be standing (unless one is acting in kethoprak or wayang orang, or one is in a palace and one's status is higher than that of other people). The wayang performance, at the same time that it is a performance, is a gathering of people, and in the midst of the sitting performers, standing up is brutally impolite. It is especially reprehensible if one stands up next to the dhalang, because the dhalang should be respected; the action is a sign of "not respecting the dhalang and the gamelan instruments," as one older musician put it. Many people feel very strongly about this, but not everybody - and this is the origin of the conflict. It is a conflict between two kinds of spatial perception, two ways of moving in space, one associated with Javanese etiquette, the other with being modern. The space is strongly traditional,

107 An antecedent of the present conflict is visible on the traditional Javanese mosques, which do not have minarets. It is said, "Here in Java, do not imitate the custom of Mecca of using minarets. According to the custom here in Java the little man may not stand higher than the king lest he be punished." 
90 Jan Mrázek

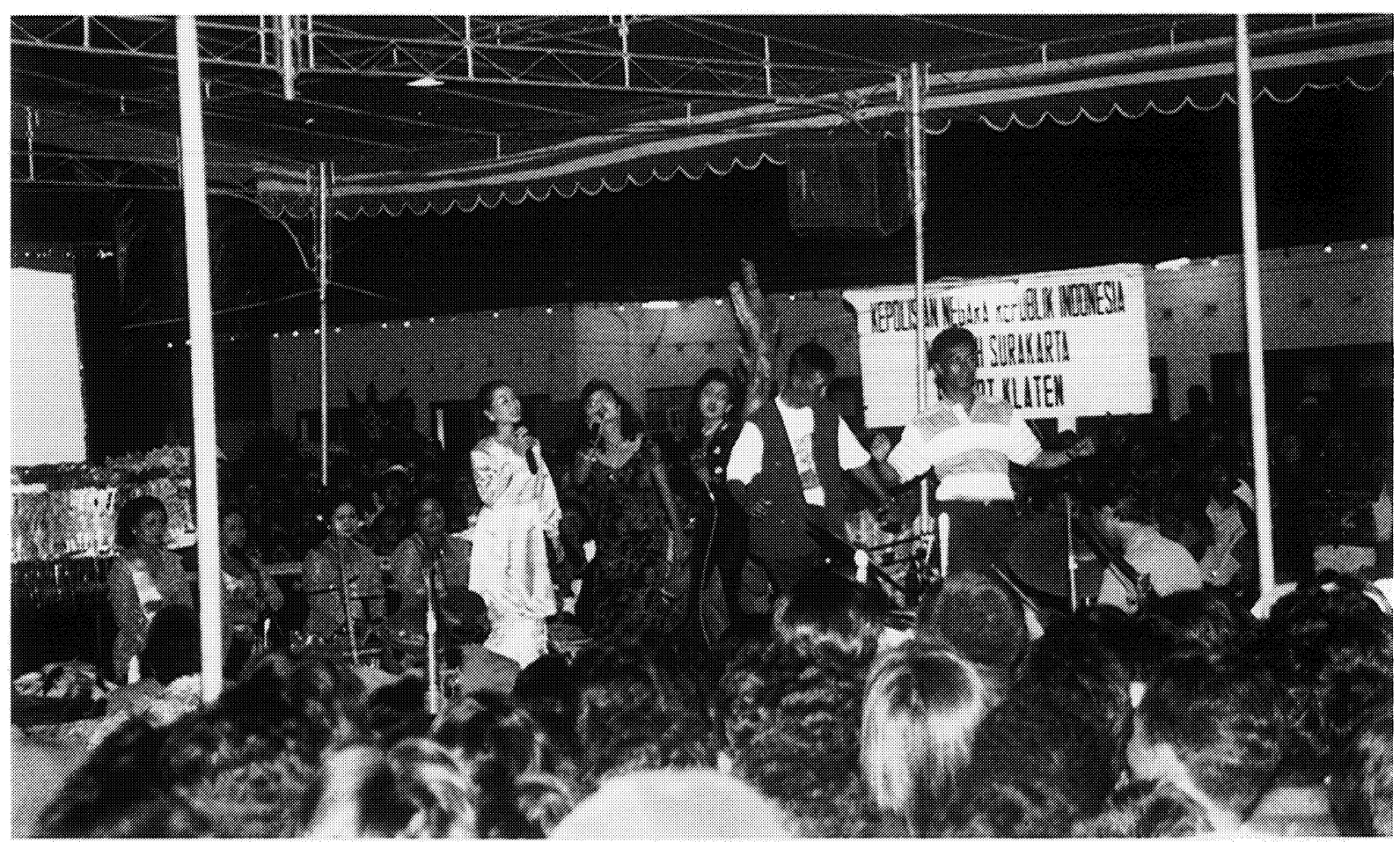

Figure 8

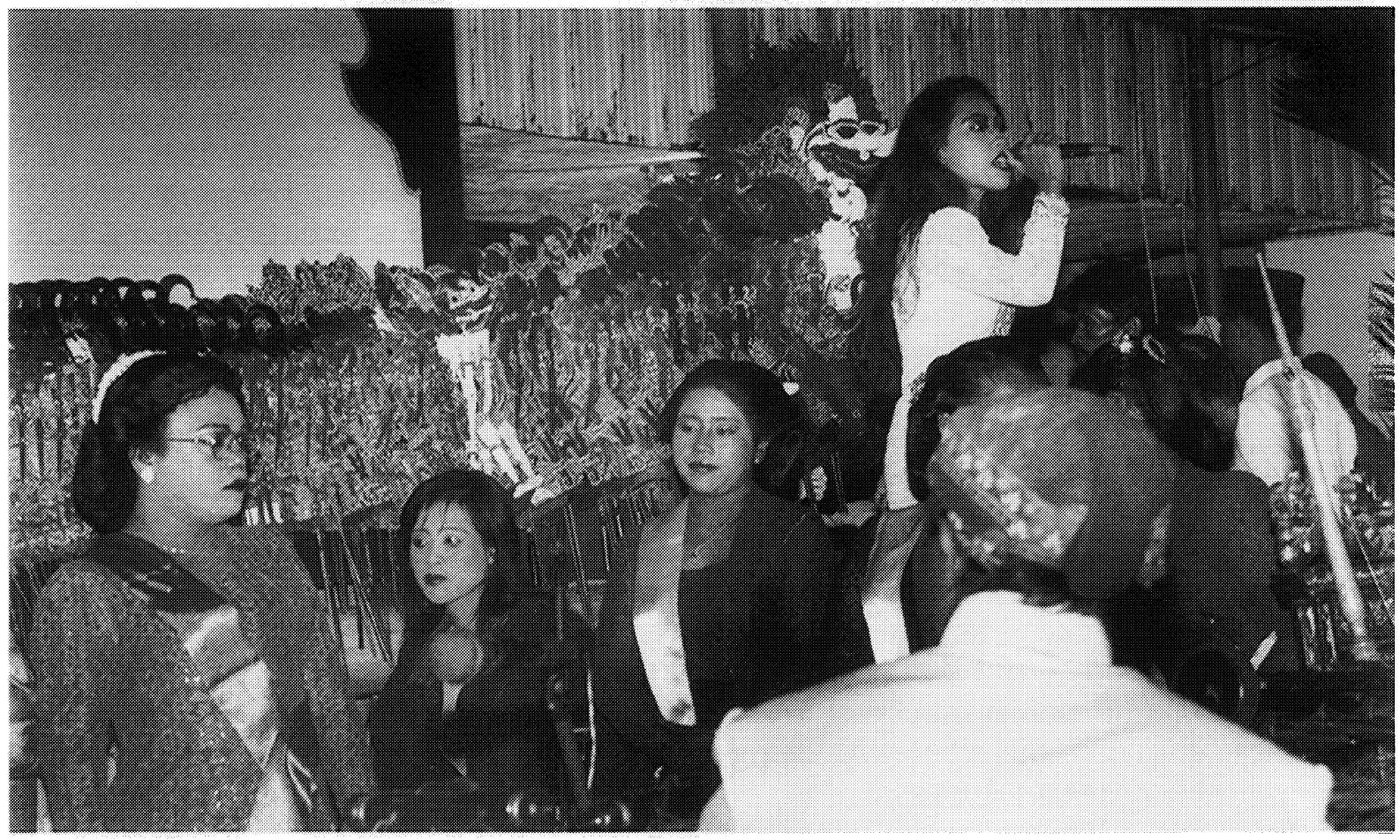

Figure 9 
strongly Javanese, but the pop singers or comedians move in it in a "modern" way. The conflict is very similar to that between Javanese and non-Javanese tunings and musics; music, like architecture, is a structure in space, invisible but physically real, and each music has a particular way of "moving around," of setting up relations, of tuning various elements together. Mixing two musics results in conflicts, as does mixing two ways of moving is space, and what one person judges to be the correct pitch or the correct interval (relation) for another will be out of tune and out of place.

The new practice of standing up on the stage has been inspired by other performance genres in which standing up is commonplace. It seems that in the practice as it has developed in recent history (that is, not taking into account possible interaction with tayuban, for instance, in the distant past) the first persons to stand up in wayang kulit in Central Java were pop singers, and in that sense the practice might be originally inspired by pop music concerts. Today, however, comedians from kethoprak and wayang orang also stand up, moving as in kethoprak or in wayang orang, and they bring these ways of moving from other genres. Also, there are various dancers, including tayuban-like dancing. Without trying to determine which was the first genre that brought standing into wayang, it is safe to say that it originated in other genres or media. ${ }^{108}$

For those who perceive standing up in the context of the traditional wayang performance, the action is impolite to the point of being obscene, like an inappropriate joke. In fact, standing up in performance is frequently associated with erection. Here is one of the many variations. A female pop singer is already standing up next to the dhalang. The audience demands the dhalang to stand up too, shouting "Ngadheg, ngadheg, ayo!" ("Stand up, stand up, come on!") The dhalang remains sitting down and, looking intently at the standing singer, says "Aku wis ngadheg kok!" ("I am already standing!"). The dhalang avoids one obscenity (standing up), by another (referring to "standing up," to erection) and thus satisfies the audience. This also suggests that there is a pleasure not only in, say, watching the erect pop singer as an erect pop singer, but also in perceiving her in the context of the wayang performance, seeing it as obscene, seeing the anarchy, the breakdown of order.

The sharp criticism of standing up reminds us that the space on the screen and the space around the screen (in which people are the actors) are components of the same structure. As I pointed out in my discussion of why the inclusion of musik is against etiquette, we must remember that when one formal aspect of the structure is disturbed, the whole performance structure is implicated. This is why the breakdown of etiquette in the space around the screen is understood as a breakdown of the performance.

Innovations have altered not only the relationships of performers to the space around the screen, but also the structure and order of the screen space itself. Normally during dialogues the puppets are set on the screen in a carefully composed, picture-like arrangement, in which one puppet (or group of puppets) faces the other puppet (or other group of puppets) across the center of the screen. ${ }^{109}$ When the dhalang talks to a pesindhen, and when this is understood as the dhalang himself talking, the screen and

\footnotetext{
108 Further research should also consider the relation of this practice to wayang traditions in other parts of Java, where the participation of dancers during the performance is in some cases common.

109 See Mrázek, "Phenomenology of a Puppet Theater," Chapter Two, for a discussion of the space.
} 
the puppets are simply disconnected from the dhalang; they are not part of the performance at that moment any more. However, the "identity" of the speaker is often ambiguous-the audience cannot be sure whether the dhalang is speaking for himself or as a character-puppet - or at least the ambiguity is vaguely suggested. For instance, the dhalang may set one or all of the clown-puppets so that they face the pesindhen. This is the new "pictorial composition" that I want to point out here: the clowns facing right, that is, facing the pesindhens and the guest stars (see Figure 10, where the two female clown-puppets talk to the transvestite comedian as the standing pop singer [right] sings). If one perceives the speaker as at least ambiguous, then the pesindhen (or a comedian), who is not merely visible but is a major visual attraction and who sits next to the screen, now speaks to the puppets on the screen. (In an interesting case, one of the clowns on the screen, such as Petruk, talks to the comedian Bagyo dressed as Gareng in wayang orang; thus a wayang kulit Petruk puppet on the screen talks to wayang orang Gareng actor on the stage.) The space of the screen is the space for encounters between the puppet-characters, but now somebody present and visible off the screen has become one of the speakers. The space of the screen is no longer privileged as the only space on which the "actors" speak, it becomes only a part of the performance space. The center of the screen, articulated by various means, is no longer respected and played with as the center, but instead its centrality is disregarded; and since the order of the space of the screen, its own architecture, is integrated into the larger architectural space, and specifically their centers and symmetries are integrated,

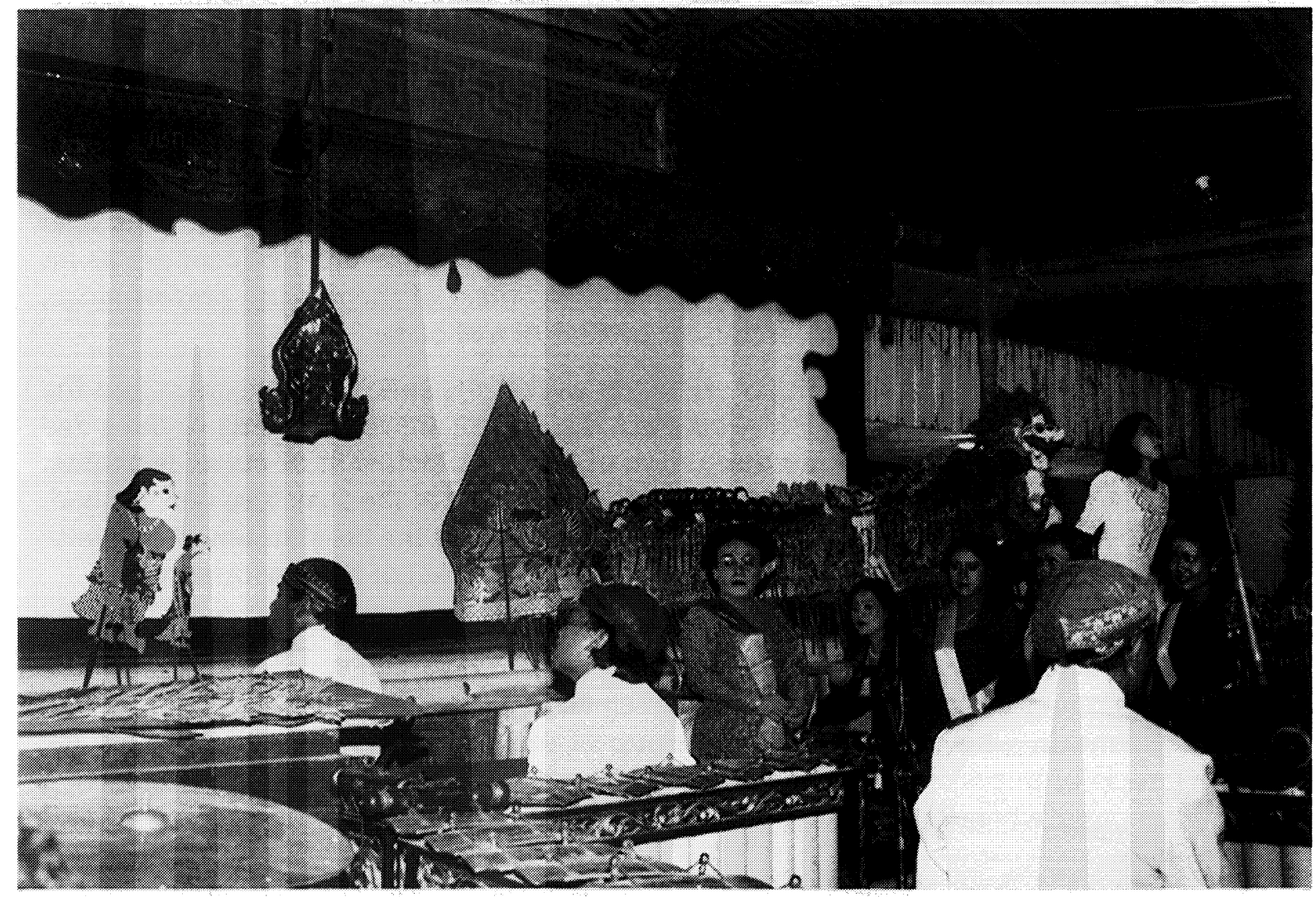

Figure 10 
the architectural space, too, is affected, as is the relation between the screen and the architecture. Thus, the way that puppets and people move in the space no longer respects and affirms, but rather disregards and covers up the spatial order. As one gamelan musician put it, the dialogue between the dhalang and the pesindhen ngilangke pakeliran. This could be roughly translated as "makes the performance disappear," but the word for wayang performance, pakeliran, is from kelir, the screen: it implies the disappearance of the screen-performance, of the way that the screen is, the way the screen is formed, or its form is respected and thus dis-covered, by the performance.

The performance that incorporates a screen and a stage is characterized by asymmetry: the screen is still in the center of the architecture, but, especially at a particular time-during the clown scenes-the center of activity, or one of the two centers of activity, moves to one side, to the right. This setup is very popular today. However, at some large-scale events, a new symmetry (at least a relatively symmetrical symmetry) has been found, and this new setup articulates spatially many of the changes that have taken place. Its basic feature is that instead of one screen and one dhalang, there are now multiple screens and multiple dhalangs.

I will focus on the most widespread variations, in which two screens are used, and there may be two or more dhalangs (however, there is always one dhalang at each screen at a time). ${ }^{110}$ There are two basic versions of this setup, rather similar to each other. In both cases, two identical screens are set up on a direct line, with a space between them (Figures 11,12, and 5, p. 82). Thus a new symmetry is established, with one screen on each side and a space in the center. In one version, the guests sit on the shadow side, in the other they sit on the dhalang's side-which is the only major difference between the two versions. In either case, there is a large stage located centrally in the symmetry established by the placement of the two screens. On the stage, center-back, the pesindhens and other guest stars are seated. When the guests sit on the shadow side, they see the stage in front of them and in the center of everything, and behind it they see, as "backdrops," two identical screens on the left and right, and between them, in the center-back, the pesindhens. When the guests sit on the dhalang's side, they see two gamelan sets, and between them a large empty area serving as the stage, and again in the back there are the two screens on the sides, and a row or semicircle of pesindhens in the center (see Figure 12). Between the screens and behind the pesindhens, there is occasionally an additional backdrop; for example, as we see in the figure, the symbol of the sponsoring political party may be displayed.

What has happened? First of all, this setup literally (that is, spatially) sets the dhalangs as well as the puppets aside, away from the center, and positions the pesindhens and their stage at the center of everything. This is articulated by the spatial relationships between the performers, the screen, and the stage, as well as by the larger architecture, even when the larger architecture is only a temporary structure. Now the stage and the pesindhen are at the center of the new symmetry, and the dhalangs sit on the sides. What has happened? The space has changed to accommodate and articulate the new structure of the performance. More specifically, the changing functional

110 There are other variations: for instance, there may be three dhalangs sitting next to each other in front of an extra wide screen. 
94 Jan Mrázek

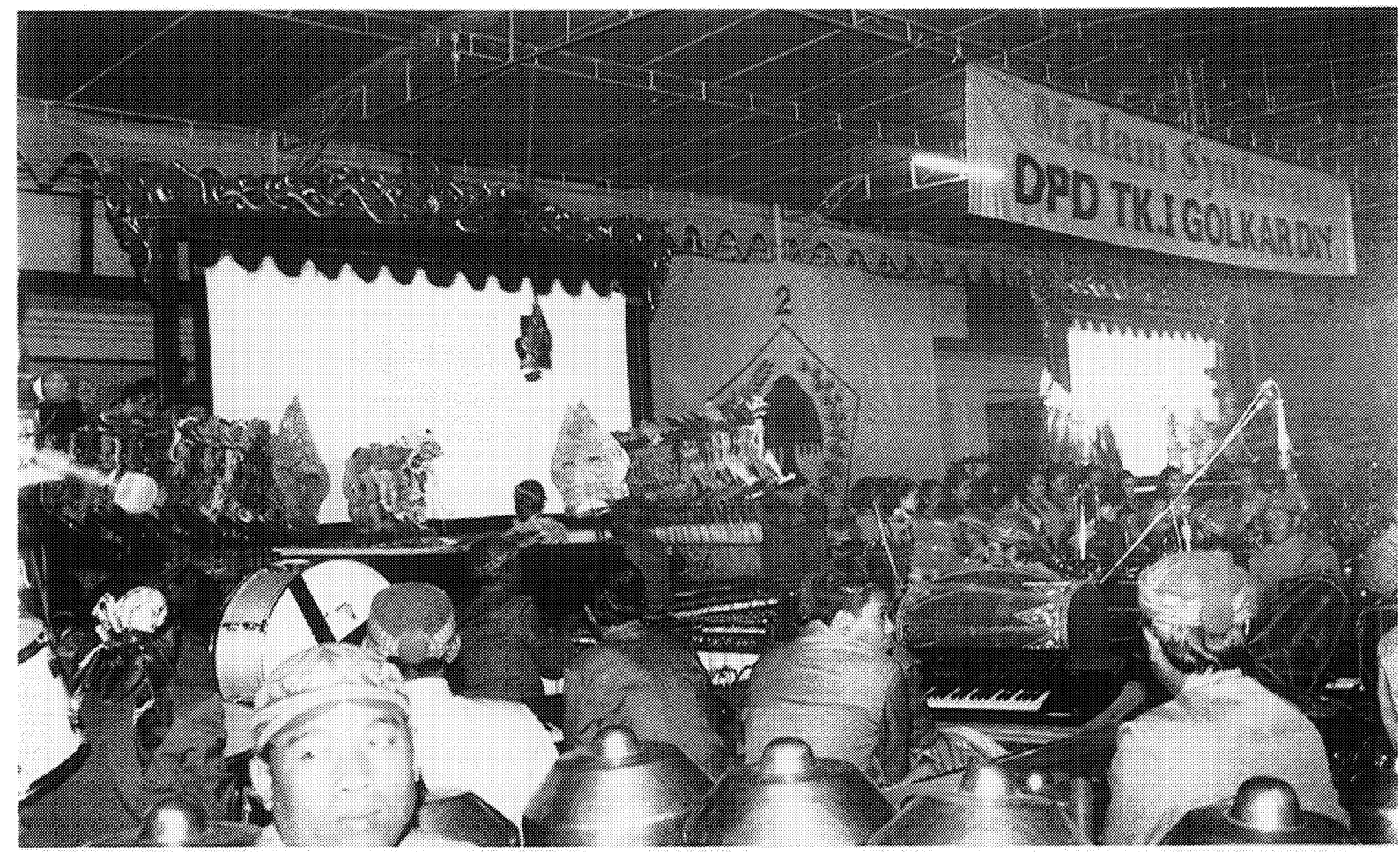

Figure 11

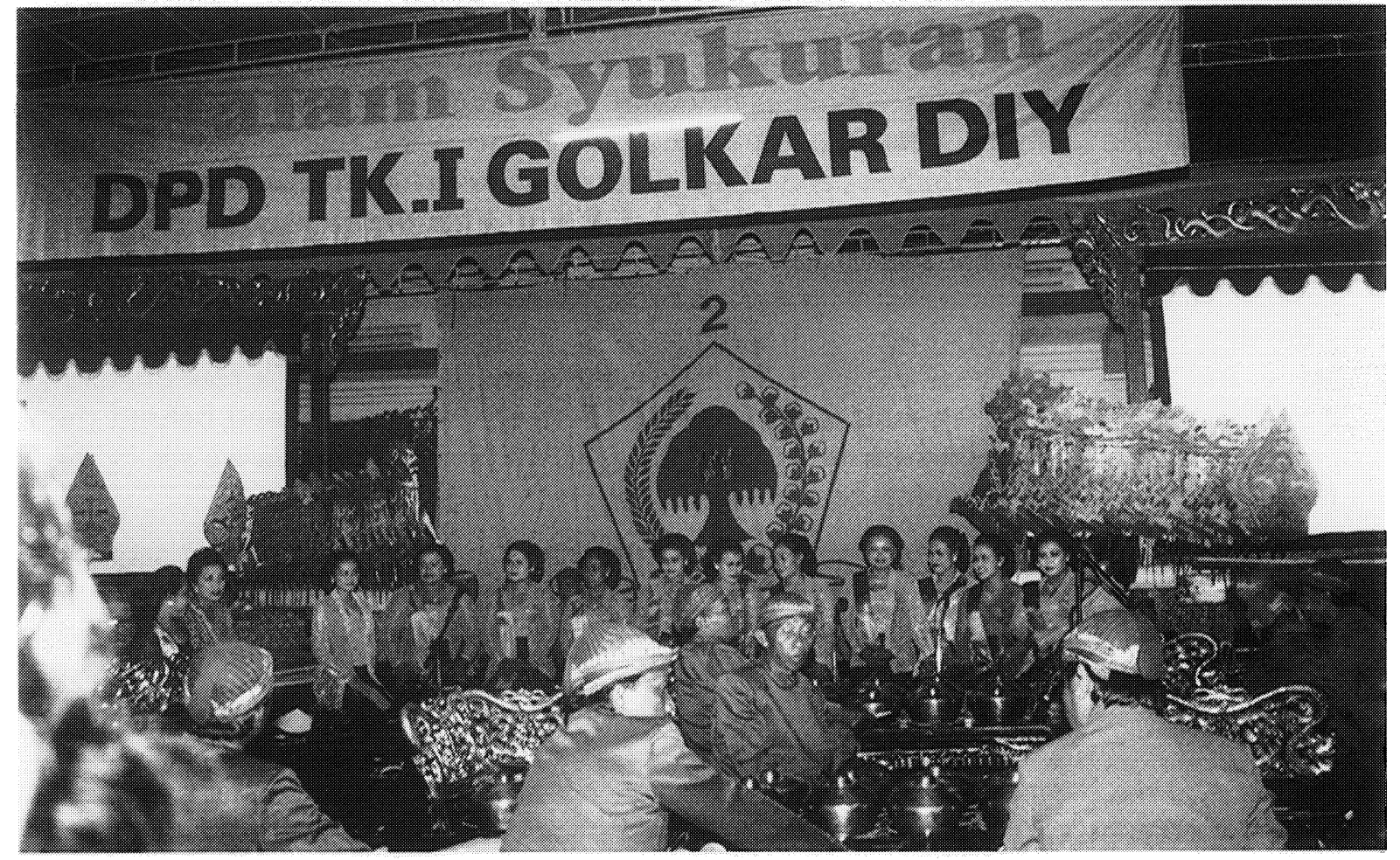

Figure 12 
relations of the performers and the performance elements are now further clarified by the spatial relations. The dhalang who, as we have seen, has been giving up his functional or structural centrality-and in traditional performance this functional centrality was also articulated by his spatial centrality-is now displaced to the side, away from the center, and the functional centrality of the pesindhens, singers, comedians, and other guest stars' is accentuated by their-the stage's-spatial centrality. The dhalangs and the puppets are set aside; at the center is comedy from kethoprak and wayang orang, songs (also the pesindhen singing with gamelan and solo; but especially kroncong/Langgam Jawa, pop, dangdut, and rock songs), dancing (associated with the various kinds of music, from jaipongan and tayuban dancing to dangdut swaying and rock rocking). The foreign, the mixed-in, the mixture itself, the gadogado, the "medley," the "pot-pourri," the outside, is now at the center of wayang. This is true especially about the clown scenes; but an important aspect of the spatial setup is that the space privileges the clown scene as the occasion which now defines the space, and the rest of the performance becomes itself foreign to the space.

In the performances with two screens and more than one dhalang, the dhalang is no longer one: that is, his powers, his sovereignty is compromised in yet another way. If in other performances he is merely one among the stars-comedians, singers, and so onnow he is only one among the dhalangs on the stage, and in this arrangement, no single dhalang is the sovereign, even when it comes to moving the puppets. (I will return to the two-screen performances when I discuss dramatic innovations.)

Another aspect of the performance space is lighting. Without going into the history of light in wayang, which is a fascinating topic, suffice to say that today, when an electric lamp is used as the blencong, there persists a memory of the oil lamp, which provokes some dissatisfaction with the electric blencong: it is strong, which is good, as people say, but it does not, as the flickering oil lamp in the past did, make the shadows seem to breathe with life, and, as an old dhalang said: "Electricity is good; it is good; but it is not nges, it is not semu"-it is not beautiful, it is not dramatically expressive. Moreover, old dhalangs say, when the oil lamp was used, the flame was adjusted so as to fit the atmosphere of the dramatic situation; for instance, it was made larger before battle scenes and smaller for sad scenes. The light enhanced the dramatic situation rather like music. In contrast, the intensity of the electric bulb remains constant, rather as if one musical piece were played throughout, regardless of the changing dramatic situation. Also, traditionally the light of the blencong (oil or electric) privileges the central space on the screen, and privileges the screen as a whole in the larger space, and thus actively participates in defining the performance space and the space of the gathering. The introduction of electricity, by the way, is often cited as the first step away from this effect. A number of dhalangs have said that before the blencong had no "competition" (saingan), for the blencong was the only light in the dark night, and this was a part of its dramatic expressiveness. The centrality of the blencong-lamp was compromised, however, when electricity was introduced and other lamps began to "compete" with the blencong. This should remind us of, and is directly related to, the compromised centrality of the dhalang: he, too, now faces "competition."

With this minimal background, we can look at what happens today: more lights are introduced, lights that are consciously related to what happens on the stage, rather 
than just being put up. Probably the first additional light, the first competitor with the blencong, was meant to illuminate the pesindhens. At first these additional lights were probably turned up during the clown scenes when requested by the sponsor or some other person; today, however, it is common to have a spotlight directed at the pesindhen, which is turned on at the beginning of the clown scene when the dhalang explicitly calls for it-the spotlight is often a part of the dhalang's hardware. The spotlight further defines the pesindhens, and the comedians who sit near, as a center, and makes people gaze at them-in this it is comparable to the microphone. When there is a stage, a space for the performers to stand up, the spotlight is directed at the stage. In performances with two screens, strong electric lights illuminate the stage, and when the guests sit on the shadow side, the shadows become indistinct. In all these cases, the lighting makes the pesindhens, comedians, and other guest stars more visible, and the screen and the puppets are no longer privileged by a single light in the midst of darkness. The darkness recedes, and with it, in part at least, imagination, ghosts, and the mysterious, strange way of seeing the puppets as alive. ${ }^{111}$

In addition to the spotlights, there are various light effects "played" in accompaniment with music. The dhalang famous for this is Warsena Slenk, and he is imitated by many other dhalangs. Slenk's lamps produce rotating strips of various colors, moving many-colored spotlights, white flashes, and moving circles of various colors (see Figure 13; one of the cannon-like lamps can be seen in Figure 3, p. 76). ${ }^{112}$

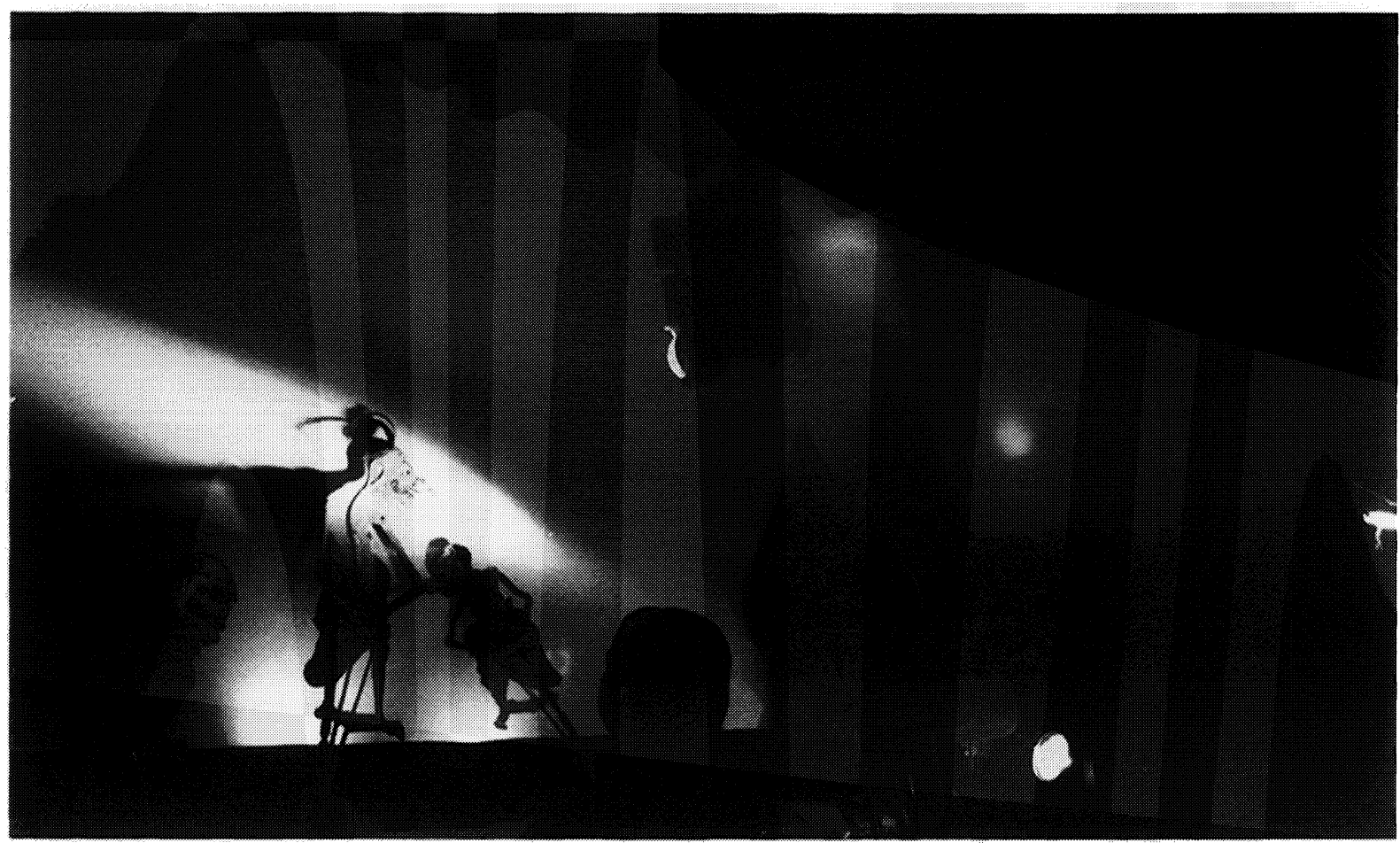

Figure 13

111 For a discussion of the theatrical function of darkness and the way it contributes to making the puppets seem alive, see Mrázek, "Phenomenology of a Puppet Theater," Chapter Seven.

112 See also Suratno, et al., Warsena Slenk: Kiatnya Sebagai Dalang Laris (Solo: STSI, 1997), pp. 48ff. 
They are used-"played" (dimainkan) - in conjunction with rock and other "hot" songs (including "Anoman Obong"). The lighting varies depending on the song, changes to suit the different parts of the song, and thus it is closely integrated with the music, it is a part of the same sound/light composition. The term "disco lamps" (lampu disco) is used both by Slenk and other people, and the use of the disco lamps is clearly inspired by disco and music concerts. Again, their appeal is not simply formal, but rather they evoke the atmosphere of disco and rock or dangdut concerts.

A kind of music is associated with a kind of milieu-created by a language, a way of behaving, atmosphere, and so forth. The singers not only sing, but also speak. The different ways of speaking that are associated with the milieu of the music they sing are brought into the performance, and in Indonesia this means different languages. "Standard" Javanese is the "home" language in the wayang that we are talking about if we speak about the relatively colloquial language used in the clown scenes. A singer from Banyumas speaks in the dialect of Banyumas before she sings her song; I have witnessed this feature in Nartosabdho's performances, as well as in the performances of Manteb, Anom, and Crazy Djoko; a dangdut or pop singer often speaks in Indonesian, though he or she may soon "return" to Javanese, and often the dhalang announces him or her in Indonesian; a rock singer, such as the one in performances of Crazy Djoko, speaks English. Moreover, a pesindhen singing a traditional part, remains usually sitting down, even when the stage is available; the rock singers, the singers of dangdut, of sentimental pop songs, of kroncong, all stand, move, or dance differently, and different dances are performed on the stage with Banyumas or East Javanese music (see Figure 6, p. 84). In the case of dangdut especially, the "obscenity" of standing up is further enhanced by erotic body movements, goyang ("swaying"), with which dangdut is strongly associated; both for fans and critics of dangdut, this swaying is an important element of the music. In some cases, the rhythmic swaying is distilled from the particular song, and the dhalang (Crazy Djoko is one dhalang who likes to do this) asks a person, man or a woman, on the stage to perform the swaying, a backand-forth movement of the hips and waist, accompanied only by the characteristic dangdut drum sounds, dang-duuut: when the drum plays dang, the "swayer" moves his or her hips back, and when the drum plays $d u t$, a rising glissando sound, the swayer's hips move forward (Figure 14 shows the male singer in that position, next to Nurhana, a langgam and pop singer). The explicitly erotic movements, which are even more sexy when the forward dut movement is enacted by a man and directed toward a woman standing next to him, as in the figure, are controlled by the dang-dut sounds of the drum. This adds more excitement-the swayer seems not to control his body. The swayer may be made to sway faster and faster, or the drummer may play several $d u t$ sounds in succession, in response to which the swayer thrusts his hips forward repeatedly, which increases the tension of the "dance" in another way. By the way, note that here, too, obscenity or "breaking the etiquette," that is, breaking the "rules," is an attraction-an attraction of dangdut music brought into wayang.

A kind of music is not only associated with a milieu, but it musically materializes it: it does not only refer to it, but, being a part of it, makes the milieu present here and now, it brings it here-or at least it has that potential, which can be either suppressed or realized, and in wayang today, it tends to be realized. The disco lights, like the moderen styles of movement and dance, are associated with the kind of music with which they are "played," and they are another part of the milieu from which the music 


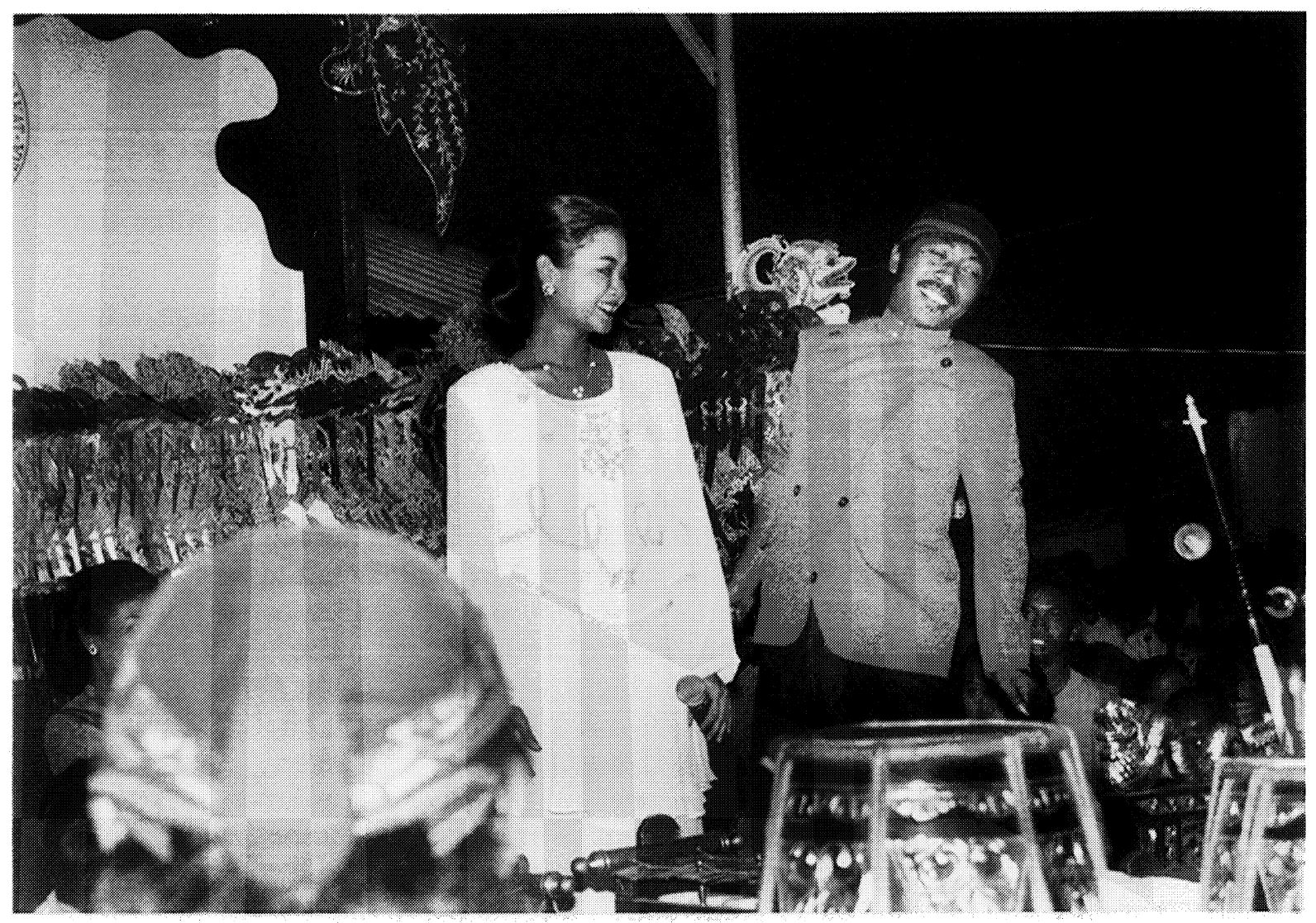

Figure 14

has come into wayang. Like music, they both refer to somewhere else, and at the same time make the foreign, non-wayang (e.g., disco, dangdut concerts) atmosphere present here. I have tried to show that when a performer stands up next to the dhalang, this is felt as a physical offense. It is difficult to describe the physical shock when, in the middle of the night, in the atmosphere of wayang and the tuning of gamelan, suddenly there are acoustic sounds of rock, the blencong disappears, and a rock singer appears dancing on the stage as swirling many-colored spotlights repaint the whole scene. One is suddenly-and not only "as if"-somewhere else: the place, the time, the way people move, have changed. The question what happens to the puppets, or the puppeteer, or between them, seems irrelevant at this moment.

This should give a general idea about what happens during the clown scenes. I should point out that while there are certain popular features and standard characteristics, each dhalang, and to some extent each performance, presents the clown scene somewhat differently. Not all dhalangs who use disco lights and rock music allow the performers to stand up; not all dhalangs in whose performances the "guest stars" stand up use disco lights; some do both, some none of it. But all clown scenes, to different but increasing degrees, are characterized by the incorporation of the foreign, by the mixing everything into one variety show ("gado-gado-ness"), by the 
diminishing centrality and compromised sovereignty of the dhalang(s) and the puppets and the attenuation of the organic bond between them, and the rising prominence of non-dramatic music and singers, comedians, as well as other guest stars; by opening to the present world and to the interaction with various other genres, media, and shows, to other ways of being and moving in space, to other tunings. In many cases, one can find antecedents to present modifications, and the innovations could be seen as a matter of change in degree. But this change in degree, the "quantity" of the innovation, seems itself the major innovation. As I said above, paraphrasing a dhalang, innovation itself is nothing new; what is new is that there is so much innovation. This makes innovation new. Ki Naryocarito realizes this when he says that today "many dhalangs consider themselves creative" (akeh dhalang sing rumangsane kreatif), 113 implying that they are not really creative: that is, they are not creative in the old way, their innovation is not the old innovation, but something else, something new and foreign.

\section{Innovations in Dramatic Techniques, and More Clownery}

First of all, I need to emphasize that this section is not a history of the development of theatrical techniques: such a history is yet to be written. Suratno, an Indonesian scholar knowledgeable about the wayang performance practice as well as Western writings on wayang, observed that the existing accounts, both Javanese and non-Javanese, are hopelessly hypothetical as far as the history of performance practice is concerned. Even commenting on existing texts is beyond the scope of this work. Here I will be looking only at very specific kinds of developments, and I will look at them only in a particular perspective. I am interested in innovations that are still felt (rather than only known) to be new, to be innovations; and I will focus on their newness, rather than their place in the long history of wayang performance. However, apart from my major focus, I will occasionally show how the innovations are also formal developments that evolved from existing dramatic techniques (though it is beyond the scope of this essay to do justice to the later perspective).

I am focusing on the innovations that are still new because they, and their newness, stand out, and are constantly discussed. This beginning betrays my conclusion. Newness in wayang, particularly the newness that stands out as newness, that is, as something of the present, rather then as something timeless, is characteristic of the clown scenes, and by looking at the newness beyond clown scenes, I am thus looking at, and discovering, certain characteristics-qualities of newness, opening to the present world - that the other parts of the performance have in common with the clown scenes. This conclusion is a product of my focus; but my focus is a product of observation of current practice, specifically the importance of innovations that are still new and whose influence extends beyond the clown scenes.

A report on a seminar on innovation in wayang in general mentions three aspects of the performance that are "considered important [items on the] menu and are decisive of whether the performance is liked by people in these times," namely, "sabet (movement-art) [sabet (seni gerak)], humor (comedy), and the appearance and skills of

113 Purnomo, HS, "Ki Naryocarito: 'Dhalang Saiki Akeh Sing Nglirwakake Bobot.'” 
the pesindhen(s)."114 I have discussed the growing importance of the clown scenes, the comedians, and the pesindhens, and here I would like to focus on sabetan, the puppet movements.

One dhalang who claims to be, and is widely recognized as, the inventor of the new style of sabetan is Ki Manteb Soedharsono. His "inventions," especially involving sabetan but also including innovative sound effects and music, are not as new as they are sometimes presented-as an older dhalang pointed out, the image of Manteb as the "inventor" is commercially motivated-but Manteb has developed and made popular a kind of sabetan, now associated with him, that is imitated by most dhalangs today, and he is in truth very skillful and creative, and his is a significant contribution to the development of performance technique. Apart from his traditional sources-that is, learning from other dhalangs-he emphasizes that he was inspired by Chinese martial arts (kungfu) movies, which have been extremely popular in Indonesia, both in movie theaters and on TV; Manteb also has his own collection of kungfu videotapes. "The process which led to my inventing the sabet used today began from kungfu films," Manteb is quoted in a newspaper report. The report continues:

as he was watching kungfu films, ideas for sabetan were flowing to him, in addition to learning better to understand the bodily movements that captivate and the gestures that interest the audience. "I have translated [terjemahkan] all that into the wayang kulit performance that I present," he said. "If there's a person crazy about kungfu movies, well that would be me," he added, laughing in his characteristic way. According to him, every time there is an opportunity, even now, he finds the time to watch a kungfu movie on TV or on video. "In the past, when there was still some free time on my schedule, it was not a problem to find time to watch. Today, if I don't give myself the time, well there is no time. So, I always give myself the time," stated the serious fan of Bruce Lee and Jacky Chen [kungfu actors]. For him, watching a kungfu movie is not merely a matter of watching. "But if I don't watch one for some time, it's like there is something wrong, something is missing," said the dhalang who with his sabetan achieved everything by worldly standards; at the very least, he can now ride his unblemished metallic-red BMW-not like in the difficult times in the past. ${ }^{115}$

How is Manteb's sabetan-and new sabetan generally-new? When I asked Manteb to be more specific about the inspiration he took from martial arts films, he mentioned two aspects of what he "translates" into wayang. First, there are certain particular movements, the most characteristic being the somersault, in which the dhalang throws the puppet into the air, the puppet "makes" a somersault in the air, and either the dhalang catches it, or it is done in such a way that the point of the gapit (the central stick for manipulating the puppet) sticks into the dhebog (the banana-trunk stage). In performance, Manteb, and other dhalangs imitating him, show off many variations and combinations of these somersaults, often with more than one puppet, which results in a kind of juggling with the puppets. Other movements characteristic of Manteb's sabetan are similar in nature: as they are often described, they are trik-trik akrobatik yang

114 "Inovasi Semakin Jelas."

115 "Ki Manteb Soedarsono: Film Kungfu," Suara Merdeka, October 6, 1996. 
sangat mengesankan-"very impressive acrobatic tricks."116 A second characteristic of his sabetan that Manteb specifically mentioned to me as being inspired by kungfu movies was kelincahan ("agility, nimbleness, friskiness"); or, as other people say, Manteb's movements are extremely quick.

As I have said, Manteb's sabetan is imitated by other dhalangs, admired by the audience, and cited as the primary reason for Manteb's fame and success. But it is also interesting to note how Manteb's critics describe the ways in which his sabetan differs from the more traditional sabetan (which is now rare). A number of people have used similar terms to describe the difference: Manteb's movements, they say, are trampil ("dexterous, skillful") and fast, but do not krasa ("feel") and the puppets do not live (urip). There is a certain lightness resulting from the agility-puppets fly in all directions-but, the critics say, a physical blow is not "felt." The focus seems to be less on presencing the feeling of the physical blow, the feeling when a living body is hit, a feeling often communicated by the slower, more deliberate movements of some older puppeteers, ${ }^{117}$ and more on the swiftness and smoothness of the movements of the puppets and the puppeteer's dexterity. In a puppet dance, Manteb's movements do not strive so much to make the puppet seem alive-trembling with the puppeteer's own life-and to express life with the dance; rather, they impress by their agility, complexity of the dance-patterns, and the puppeteer's virtuoso dexterity.

When I talked to Manteb about this criticism, he disagreed and justified himself, but he used the same terms to criticize his imitators. He said that indeed his "sabetan is dexterous sabetan" (sabetan kula pancen sabetan trampil), but that if sabetan is fast and dexterous, it does not mean that it cannot "feel" (kraos/krasa) and animate the puppets (urip), and that his does feel and is "living." It is his imitators, he said, that take over the speed and the displays of dexterity, but their puppets do not live and the sabetan does not "feel." (When I asked him whether there is not a single young dhalang whose sabetan feels and is alive, he said "not yet.") Of course, such responses have also a political motivation, but Manteb as well as his critics agree on the general direction that the development of sabetan is taking: from focus on "feeling" and "living" to focus on high speed, agility, and dexterity in performing exciting trik-trik akrobatik. ${ }^{118}$

The new sabetan makes for a different kind of life: life as liveliness, a liveliness as excitement that results from agility. Manteb's sabetan, people often say and write,

\footnotetext{
116 E.g., in Sugeng Nugroho, Skar., "Keleluasan 'sanggit' kreativitas bagi seorang dalang," Gatra 25 (1990).

117 On the physical blow in wayang, and the "presencing" of physical sensations in wayang, see Mrázek, "Phenomenology of a Puppet Theater," Chapter Three.

118 I feel these terms describe well a particular tendency, but I should point out that in Java the standards are very high, and the differences, especially in what is lacking, are often subtle-it is easy to see that the new sabetan is faster and includes the acrobatics, but, in most cases, one needs to be a connoisseur (or dislike or envy Manteb) to tell that a puppet, held by a dhalang such as Manteb, is not alive, or that a blow does not feel-and, having held a wayang puppet in my hand myself, having tried to hold it, I am especially hesitant to say... anything. (Here at least, my experience in learning performance technique, and my respect for dhalangs resulting from it, is an obstacle for writing.) The old dhalangs are certainly dexterous, and the younger dhalangs can make the puppets, to a great degree, alive. Also, the dhalang's dexterity is appreciated even in the older sabetan. But this does not mean that the distinctions between older and newer sabetan are not clear enough; but they are a matter of differences in style, in feeling, and they are not as vulgar as my description may make them appear.
} 
makes the performance more alive (luwih urip/lebih hidup). ${ }^{119}$ There is a change of focus in the terms used to describe the developments: from life in the puppet, to another kind of life, or liveliness, the liveliness of the show. (Traditionally, the Javanese word greget denotes the dramatic liveliness of the performance.) The puppets do not have to appear living in order for the show to be lively. This is strikingly clear from a description of innovative techniques in the West Javanese puppet theater (wayang golek), in some ways very much like those that we are discussing:

From its [a puppet in a fighting scene] mouth spurts fresh blood. The spectators shout wildly. There are those who laugh uncontrollably, and there are those who keep screaming. [ . . . ] Such is approximately the performance of a sophisticated wayang golek, which has today more and more fans. New things, or new techniques, make the performance more alive [semakin hidup]. ${ }^{120}$

Note the wording: from a puppet's mouth "spurts fresh blood," which is precisely what makes the performance "more alive." Similar terms are used in another part of the text: "In [a particular dhalang's] hands, traditional wayang golek appears alive [bernyawa]. The head of an ogre can be severed and . . out streams blood!"121 The performance becomes more alive as the puppet spurts blood, or as its head is severed.

Bloody horror movies and other violent films present themselves as likely inspirations for these developments; dhalangs speak about film-like "realism". A kind of popular TV show also comes to mind: the sports show. In wayang, battle scenes are visually the most exciting parts of the performance, and the movement in battle-scenes is in some ways puppet-movement at its best. (Sabetan, the general term for puppet movement, is also used more specifically to describe puppet movement in battle scenes. The word comes from the root sabet, "to hit, slash," which too reflects the centrality of fighting to wayang movement). ${ }^{122}$ The excitement of the battle scenes is not unlike the excitement of watching a soccer match, or a boxing championship-both soccer and box are very popular in Indonesia, the later especially on TV; again, here the new Sundanese wayang golek shares much with the new Javanese wayang kulit. Another excerpt from the description of the wayang golek performance described above further clarifies this association: "The battle scenes displayed seem to heat the atmosphere even more. [ . . . ] 'Come on, Gatotkaca! Hit his head, pull his hair!' shout the spectators." 123 Dhalangs occasionally use references to sports, and the puppet of Mike Tyson, the American heavy-weight champion, is used by a number of dhalangs. The song/cry "ole ole," used to excite the bulls, matadors and others at bull fights in Spain and later taken over by soccer fans, is occasionally incorporated into fighting scenes, either sung by the dhalang or even played on gamelan; and while the history of "ole ole" goes as far back as the Muslim presence in medieval Spain (it comes from

${ }^{119}$ For instance, Amien Nugroho writes about new sabetan, which "resembles a fighting scene in a film," as well as other innovations, that they make "performance become more alive [hidup]." See Amien Nugroho, "Pagelaran Wayang Kulit Perlu Pembaruan?," Kedaulatan Rakyat, September 29, 1991.

120 Heryus Saputro, "Ade Kosasih Sunarya: wayang golek pakai komputer mengapa tidak?," Femina 17,6 (1989): 65.

121 Ibid.

122 See Mrázek, "Phenomenology of a Puppet Theater," Chapter Three.

${ }^{123}$ Heryus Saputro, "Ade Kosasih Sunarya," p. 65. 
"Allah Allah"), in Indonesia it is primarily a reference to bullfight-like soccer seen on TV. In a televised wayang performance I saw, Bayu, a new teenage dhalang-star, was showing off his spectacular performance talents, taking the place of his father, Anom, as dhalang for the battle scenes in one of his father's performances, and as one character dealt a decisive blow to his enemy, the two comedians present on the stage jumped up and slapped each other's hands ("high-five") as when a team scores in basketball. In another performance, this one at the radio station in Surakarta, a young dhalang, Edy Sulistyana, commented in a clown scene:

Wayang is [by other dhalangs] mixed [campur] with comedy, with dangdut, with [Western] theater [teater]; I am also going to make an innovation [aku ya arep kreasi]: I will mix [campur] wayang with soccer [balbalan]. ${ }^{124}$

A two-dhalang performance was called "A contemporary Duel [Duel] Manteb Oye Vs. [Vs.] Crazy Djoko," both "duel" and "vs." being from Dutch or English and alluding to sports. ${ }^{125}$ When I interviewed Crazy Djoko (after I had to wait for the end of a boxing match that he was watching on TV), he said that the difference between him and Manteb is that while Manteb learns from kungfu movies, Djoko looks for inspiration in TV cartoons and boxing. An ex-boxer himself, he said that he likes OK watching Indonesian box, but he is a "maniac" (maniak) when it comes to foreign boxing. As an example of how boxing inspires his performances, he mentioned "slow replay" which he incorporates into battle scenes. These few examples illustrate that sports shows-especially as seen on TV-constitute another kind of "show" interacting with wayang, and wayang is "married" to it, or at least flirts with it, particularly in respect to the "liveliness" and excitement of the performance.

I have discussed elsewhere how the holding of the puppet, and the communication or infusion of the puppeteer's "heart-trembling" and the "dhalang's life" through his arm and hand into the puppet (as one puppeteer has described it), is central to making the puppet appear alive. ${ }^{126}$ When the puppet leaves the puppeteer's hand, as in a somersault, the flow of life is interrupted, and the puppet's life sacrificed for a different effect: the acrobatics, the liveliness of the show. One dhalang explained that when a good dhalang holds a puppet, however bad the puppet may be, the puppet looks agung, "exalted, noble, grand." He said a dhalang should always respect the puppets, and somersaulting a puppet shows disrespect to the puppet, so the effect is lost; this is a standard criticism of "lively" new wayang. (Somersaults are especially criticized, even by Manteb, when a high status character is involved; somersaulting an ogre seems less offensive.) Again, somersaulting the puppet is a matter of sacrificing the intimate, organic bond between the puppeteer and the puppet, and a matter of the puppeteer, for a moment, not respecting the puppet. Other very popular new movements are criticized for the same reasons, such as when the dhalang throws a puppet flying off the screen (sometimes at the pesindhen), or when he intentionally demolishes a puppet. The various displays of disrespect for the puppets can make some old dhalangs really angry, and the young spectators love it, as it enlivens the

124 The performance took place on October 19, 1996.

125 "Duel Kontemporer Manteb Oye Vs. Djoko Edan: Semar Jadi Dewa Khusus," Kedaulatan Rakyat, July 27, 1997.

${ }^{126}$ Mrázek, "Phenomenology of a Puppet Theater," Chapter Three. 
show. One important-though in some cases subtle-distinction should be noted: when a wayang puppet is tossed or demolished, it is not merely the character who is killed for the sake of making the show more alive, for that may also happen in more traditional performances; here the puppet itself is mutilated, or disrespected, by the dhalang. Thus, we find signs of the same development that we did in our examination of the clown scenes: the organic bond between the dhalang and the puppet is disintegrating, and is sacrificed-to some extent-for the sake of other attractions. In these attractions, too, the destruction of the theater is a part of the theater's appeal, and it makes the show "lively." 127

The newness of Manteb's sabetan is a product of the interaction with another medium, namely film. It is clear that Manteb is not the only one who associates his sabetan with martial art films. One writer mentions that Manteb's "[f]ighting scenes appear like a scene of a Chinese martial art film full of action."128 Another writer speaks of innovations in sabetan generally (though he mentions Manteb), writing that the new sabetan "resembles [mirip] a fighting scene in a film."129 Pak Naryo, too, said that Manteb's sabetan is "just like pelem kumpu," and, as I realized only on my way home on the Kertosuro-Solo double-decker bus, "pelem kumpu" is "filem kungfu." In other words, the films-by wayang fans seen mostly on TV-are not only an inspiration for the movements, but the movements "resemble" the films, the movements are seen as coming from the films, as being inspired by them, and being like them. This is true not only about sabetan, but also about some other dramatic techniques now commonly used by Manteb as well as other dhalangs, such as the proloog (a section, mostly focusing on sabetan, added before what is traditionally the first scene in the performance, and usually showing certain important moments or characters in the story to be told) and flashback (a dramatic representation of events that would be, in a traditional version, only narrated by the dhalang or told by a character) which are both readily identified as film techniques. ${ }^{130}$ Pak Naryo, for instance, said that flashback "imitates film (niru pelem)." The point is that the new sabetan and some other techniques are, and are seen as, film techniques introduced into wayang or products of interaction with films (especially films on TV), as elements that have been incorporated into the wayang performance from films. And Manteb's sabetan is only one example; other dhalangs also watch TV. The popular puppeteer Enthus Susmono, for instance, said that the creation of a new, superduperextralarge puppet which he often shows off in his performances, was inspired by comic strips and the

127 The politically-motivated terms taken up in the Javanese discussions, especially the criticisms, focus on the differences between the old and the new, and downplay the continuities. Even in more traditional performances, the fights make the performance alive, they too are an attraction, and there are various technical tricks impressing the spectators. While this is important to keep in mind, it does not hurt to have taken advantage of the Javanese discussions' bias, and learn something about the differences between the old and the new.

128 A. Komar Abbas and Seno Subro, Ki Manteb "Dalang Setan" (Surakarta, 1995), p. 142.

129 Amien Nugroho, "Pagelaran Wayang Kulit Perlu Pembaruan?"

130 Manteb was not the first dhalang to use flashback, but he has popularized it. 
films King Kong and Jurassic Park; 131 and in his performances he "even shows off wayang-puppets of dinosaurs from Jurasic [sic] park."132

Thus, here we find innovation in dramatic technique sharing characteristics with many innovations in the clown scenes: innovation is a matter of taking over and incorporating, being inspired by, or imitating certain other genres or media. As such, innovation is a symptom of the opening of wayang to the interaction with other media in the present world. Since the movements and other dramatic techniques are not only inspired by, but are felt to be like films, the new movements refer to films and TV, and I believe this reference to the foreign, and the recognition of such innovations as still new and foreign in wayang makes the performance interesting for the audience.

This becomes more obvious when we look more carefully at the interaction between films and wayang, and more generally TV and wayang, an interaction that today is an extremely important factor shaping the wayang performance. ${ }^{133}$ However, I will need to say first more about radio, which is the major precursor of TV.

I have mentioned on a number of occasions the crucial role of radio in wayang performance. Ki Nartosabdho began the rise to popularity as a dhalang in wayang kulit only after he had begun performing on radio in 1958, and his popularity was later enhanced by his cassette recordings. As Sumanto writes, "Nartosabdho succeeded in achieving an important position among the Indonesian people thanks to his ability to anticipate people's tastes and his success in entering modern media such as radio and the cassette industry." 134

[R]adio at that time [the late fifties and sixties] was the single most widespread modern medium, and it was very effective as a means for [making a dhalang] popular. According to Mudjoko Djokorahardjo [Nartosabdho's drummer; but also an influential dhalang who is credited with the introduction of flashback into wayang performance], radio broadcasts of wayang were the pride of dhalangs [who performed on radio]. Not only was [a radio broadcast perceived] as the government's recognition of a dhalang's abilities, but it also made them [the dhalangs performing on radio] well-known among wayang lovers. Nartosabdho's intention to be broadcast from RRI Jakarta [the state radio station in Jakarta], too, seems to be to achieve recognition by the government for his abilities as a dhalang, and at the same time to become known among wayang lovers. Since that performance in RRI Jakarta [in 1958], Nartosabdho began to receive invitations to perform wayang kulit [while he was still a musician in the wayang orang group]. ${ }^{135}$

Radio broadcasts and cassette recordings of wayang performances by a number of dhalangs were-and still are-imitated by, or inspiring to, other dhalangs. Not only the individual performer was popularized, but a particular way of performing wayang

131 Kholiq, "Babat alas metropolis dengan Betara Kala 2 meter," Jawa Pos, October 24, 1997.

132 "Clekit Berdialog Dengan Nasiroh," Jawa Pos, October 26, 1997.

133 In this essay I examine the interaction of wayang and TV only from a particular perspective and only in the context of the questions of this essay. My present research, a part of the Verbal Arts in the AudioVisual Media in Indonesia Programme at Leiden University, focuses more specifically on the interaction of the two media.

134 Sumanto, Nartosabdo, p. 70.

135 Ibid., p. 59. 
became well known, a way already affected by radio. Radio not only disseminated new ways of performing; it also gave them authority. Later dhalangs, especially Anom, and their styles, have become popular, or standard, in a similar way, and have been imitated by other dhalangs (for instance, Anom's voice quality is widely imitated, as is his music).

In addition to noting the long-time historical interaction between wayang and radio, we must also note the complexity of the interaction. Anom may be the more obvious example, since, after Nartosabdho, he is probably the most popular dhalang on radio as well as on cassettes, in part because his, like Nartosabdho's, performances emphasize the musical and the verbal; or perhaps, in part, because his emphasis on the musical and the verbal fits the modern media. He can now be heard several times a week on radio. But let us rather look at Anom's younger brother, Warsena Slenk, one of the younger dhalangs whose performances I frequently attended, who has become extremely popular in the nineties-Anom has been popular since the seventies-and whose performances and rise in popularity have been recently analyzed by Suratno. ${ }^{136}$ Suratno presents the relation between Warsena Slenk and radio stations as a two-way interaction in which both sides have a stake. Thus he goes beyond saying that wayang competes with other media, and looks at the nature of their interaction:

Warsena is aware that mass media are a powerful means for [Warsena's] promotion and publicity in his efforts to clear a path for his popularity. Because of that, in 1994 he has permitted people from private and local state radio stations to come and record, or broadcast live, his performances. He also welcomed several broadcasters, both from Surakarta and outside, who borrowed cassettes from him to be broadcast at a particular time. [ . . . ] This year, two radio broadcasters invited Warsena for an interview with his fans, broadcast live [ ... ] In return for the services of the radio employees, Warsena often gives a tip and/or tali asih ["love rope": a gift to establish a closer relationship] in the form of T-shirts, stickers, or cigarettes, to the radio employees, as well as to his fans. [ . . . [T] [Tere is cooperation that profits both parties. From the point of view of the radio, broadcasting Warsena's performances will increase the number of listeners. On the other hand, looked at from Warsena's side, as his performances are broadcast on various radio [stations], his influence [popularity] among people will expand.137

Warsena Slenk, who is famous for his presentation of currently popular pop and rock songs, learns these from radio, as well as from cassettes and TV, and he also learns from recordings of Nartosabdho's and Anom's performances. ${ }^{138}$ As I have pointed out in my discussion of songs on request, Anom's performance-the same is true about Slenk's - is in some respects like a radio program, and live performances recorded or broadcast by a radio station are shaped by the radio's presence, they are perceived and performed with the awareness that they are also radio programs. When there is a wayang performance broadcast on the radio, the two media merge in a

136 Suratno, et al., Warsena Slenk.

137 Ibid., pp. 54-55.

138 Ibid., p. 45. 
strange way-people listen to wayang at the same time that they listen to the radio. Wayang performances are an important component of radio programming; one can hear all-night wayang performances on the radio almost every night. Thus it is not surprising that some aspects of radio programming have become an important part of wayang performances, so that one must consider the role of radio in order to understand wayang performance. Also, the radio-wayang broadcasts are a part of the "wayang scene." They are among the wayang performances in the present world, and since, for instance, the late Nartosabdho's performances are still popular and often broadcast, radio participates in shaping what the contemporary wayang performance. Therefore Nartosabdho is still "alive" on the radio-he is still a popular and influential dhalang - and still imitated. ${ }^{139}$

While radio and cassettes continue to be important today, the presence of TV is felt more and more strongly. Since the 1980s and especially since 1995, when Indosiar began to broadcast wayang regularly every Saturday night, it has increasingly been a major factor in shaping wayang performance and the way that wayang performance is in the world. As one can see from the discussion of radio, rather than merely saying that now wayang has to compete with the modern media-a standard observation, and not incorrect-we need to go further, examine the nature of the competition, and see that wayang's being together with the modern media in the present world is not only a matter of competition, but of a complex interaction.

With this background, we can come back to our examination of the context of the new sabetan inspired by kungfu films on TV. Wayang's complex interaction with TV is reciprocal. The major difference between the influence of radio and TV is that TV emphasizes the visual components of the performance, while radio (and cassettes) leave these out. Accommodation to a TV medium has led to a major change in wayang technique: the increasing importance of sabetan as opposed to narration and dialogue. The "movement moments," and especially fighting scenes, have been expanded, and there is a greater focus on making these scenes spectacular. Manteb told me in an interview that when performing on TV, one has to "show many attractions [atraksi], narration must not be too long, and the mood songs should be short." TV is not the only factor that motivates these tendencies, but it is an important one. Manteb's rise to prominence, his graduation from being one among the many good dhalangs to becoming one of the few superstars, is a part of this process. In 1988, Bambang Murtiyoso, Manteb's biographer and consultant, asked rhetorically: "Is not one of the reasons for Ki Manteb Soedarsono's rising popularity now the service of TV?"140 Manteb's speaking and singing abilities are not impressive. This is due partly to what one journalist described to me as the faktor gigi, "the teeth factor": Manteb has not had any teeth for some time. Manteb is heard rather infrequently on radio, and the several performances recorded on cassettes have not been a success, but he is one of the most

139 In this respect, much of what has been said about radio applies to the cassette industry. For a discussion of wayang on cassettes before the advent of wayang on television, see Ben Arps, "Volkstradities en instituties in het Middenjavaanse wayangtheater," in C. P. Epskamp, ed., Theater op Java (Zutphen : De Walburg Pers, 1985), pp. 47-50.

140 Bambang Murtiyoso, "Mencari upaya dan usaha meningkatkan kesejahteran seniman seniwati pedalangan," Gatra, January 19, 1988. See also Bambang Murtiyoso, Faktor-faktor Pendukung Popularitas Dalang (Unpublished S-2 Thesis, Universitas Gadjah Mada, 1995). 
108 Jan Mrázek

popular TV-dhalangs. Manteb's emphasis on sabetan, on (visual) "action," fits the TV medium, rather like Nartosabdho's and Anom Suroto's performances fit radio.

As in the case of the radio, the interaction between TV and wayang is a complex one, and both wayang and TV profit-or try to profit-from the association. Indosiar, a nation-wide private TV network, broadcasts wayang performances regularly on every Saturday night. Other private TV stations, as well as the state TVRI, broadcast wayang occasionally. On Saturday nights especially, it often happens that there are wayang performances on two or three out of the five or six channels. Initially an experiment, today wayang performances on TV are very popular. Many people, especially middle-class members of the audience, find it more comfortable to watch wayang on TV.

[T] he presence of wayang performance on TV has been immediately welcomed by our society's supporters of this traditional art. People feel happy to be able to watch wayang kulit without incurring any expenses or having to leave the home. And even the dhalang is different every time. Even though the performance cannot be enjoyed as when one watches a performance directly-where spectators interact with other spectators, they can talk to each other, can clap hands, laugh, and enjoy wedang rondhe [a sweet, spicy, fruity, soup-like beverage] and other things-at least the audience of the traditional art can still afford to enjoy the presentation of the performance without having to sacrifice too much time, energy, and money. ${ }^{141}$

Wayang on TV is an important part of TV programming and an important form of wayang in the present world. Today, it is considered more prestigious for a dhalang to appear on TV than to be heard on radio, and TV has become more important in the diffusion of the styles of various dhalangs. Not only can dhalangs imitate also the visual components of the wayang performance, such as Manteb's sabetan; perhaps more importantly, audiences come to expect the kind of performance they see on TV-and indeed, if Nartosabdho's and Anom's voicing techniques and jokes are becoming the standard among the majority of dhalangs, it is difficult today to find a dhalang who does not imitate Manteb's sabetan (even Anom does to a great extent). If Manteb's sabetan was inspired by films on TV, it is again TV that plays a major role in disseminating Manteb's "translation-into-wayang" of kungfu films. Moreover, the "translation" of kungfu into wayang, when broadcast on TV, is among the kungfu films on TV: the "translation" is now seen next to the "original," so that it has become part of the same medium, the same super-show, the TV.

However, the imitation of kungfu movements in wayang performances is not the only development resulting from the interaction between wayang and TV. The TV medium affects wayang more aggressively than radio. The dhalangs have to change the form of the performance much more radically if it is to fit the TV medium. This act of "fitting" the two media together to produce TV-wayang is seen in terms very much like those used when critics discuss the mixing of Javanese and Western music:

The "marriage" ['perkawinan'] of traditional [tradisi] art with electronic mass media [media massa elektronika] cannot be evaded any more. In the beginning, this

141 Sarworo Sp, "Pergelaran Wayang Kulit di Televisi: Dalang Ditantang, Dalang Bisa 'Kelimpungan,'" Kedaulatan Rakyat, September 15, 1996. 
"marriage" has happened between traditional art-a specific performance artwith radio and cassette technologies. Now, it is between traditional art and the television. ${ }^{142}$

This "marriage," according to Pamudji, is a matter of "culture crash [tabrakan budaya] between the art of our traditional culture with the art of modern-global [modern-global] culture represented by sinetron [sinema elektronic, "electronic cinema," usually referring to TV soap operas]."143 Pamudji writes that the "stumbling" (a term borrowed from Umar Kayam) of wayang (and kethoprak) on TV comes from the fact that TV and wayang have different principles (kaidah), and wayang is "stumbling" as it tries to adjust to the principles of the TV medium. To get over the "stumbling," wayang "has to be ready to accept various eliminations and additions of artistic-technical principles." 144 The writer points out that certain parts of wayang (e.g., dialogues and narrations) "'disregard the visual aspect' which is the specialty of this audio-visual medium [TV]"; 145 or, more precisely, what is "disregarded" at those moments, or rather separated and left for a later time, ${ }^{146}$ is the visual-kinethic component, that is, (puppet) movement. Thus, as in the case of Campursari, in which gamelan is tuned to the keyboard, wayang has to be "tuned" to TV; at the same time, producing wayang on TV is a "marriage" of two media, and both are implicated, and it is also a marriage of the traditional Javanese with the foreign, the "global-modern." The "stumbling" is analogous to the dissonances in Campursari music that results from the differences in tuning, from the differences between the "principles" of the two musics, or, in the case of the "stumbling," of the two media.

On the one hand, this "stumbling" "marriage" can be improved by appropriate television techniques. Umar Kayam, for instance, says that "wayang performance for TV broadcast [ . . . ], ideally, must be fashioned [digarap] with the support of many cameras, so that it is picture-rich [ . . . ] But on Indosiar it is already good." 147 On the weekly wayangs on Indosiar, the sections of the performance that are traditionally still, when the puppets move little or not at all, have been enlivened by a different sort of movement and visual display: one produced by the cameras' "eyes." The picture is all movement: movement between different shots of the screen, of the puppets (often in close-ups), of the dhalang (long view; close up of his face in profile; close-up of his face from the front), sometimes moving to a long view of the row of pesindhens or an extreme close up of a pesindhen's face (this one is especially popular); a long view of the gamelan; a close-up of individual musicians (including the keyboard and drumset players). (See also Figure 15.) Various special effects are used: a close-up shot of the dhalang's face is mixed in one picture with a long shot of the gamelan orchestra and the screen, resembling a surrealist painting, or a smaller picture of a pesindhen's face is inset into a larger picture showing the puppets.

\footnotetext{
142 Ibid.

143 Pamudji, “Ketika Panggung Ketoprak dan Wayang Diusung ke Televisi,” Suara Merdeka, August 9, 1997.

144 Ibid.

145 Ibid.

146 On this separation of "modes," see Mrázek, "Phenomenology of a Puppet Theater," Chapter Six.

147 Quoted in "Perlu Diperbanyak Pentas dengan Garap Sanggit," Kedaulatan Rakyat, September 7, 1996.
} 
110 Jan Mrázek

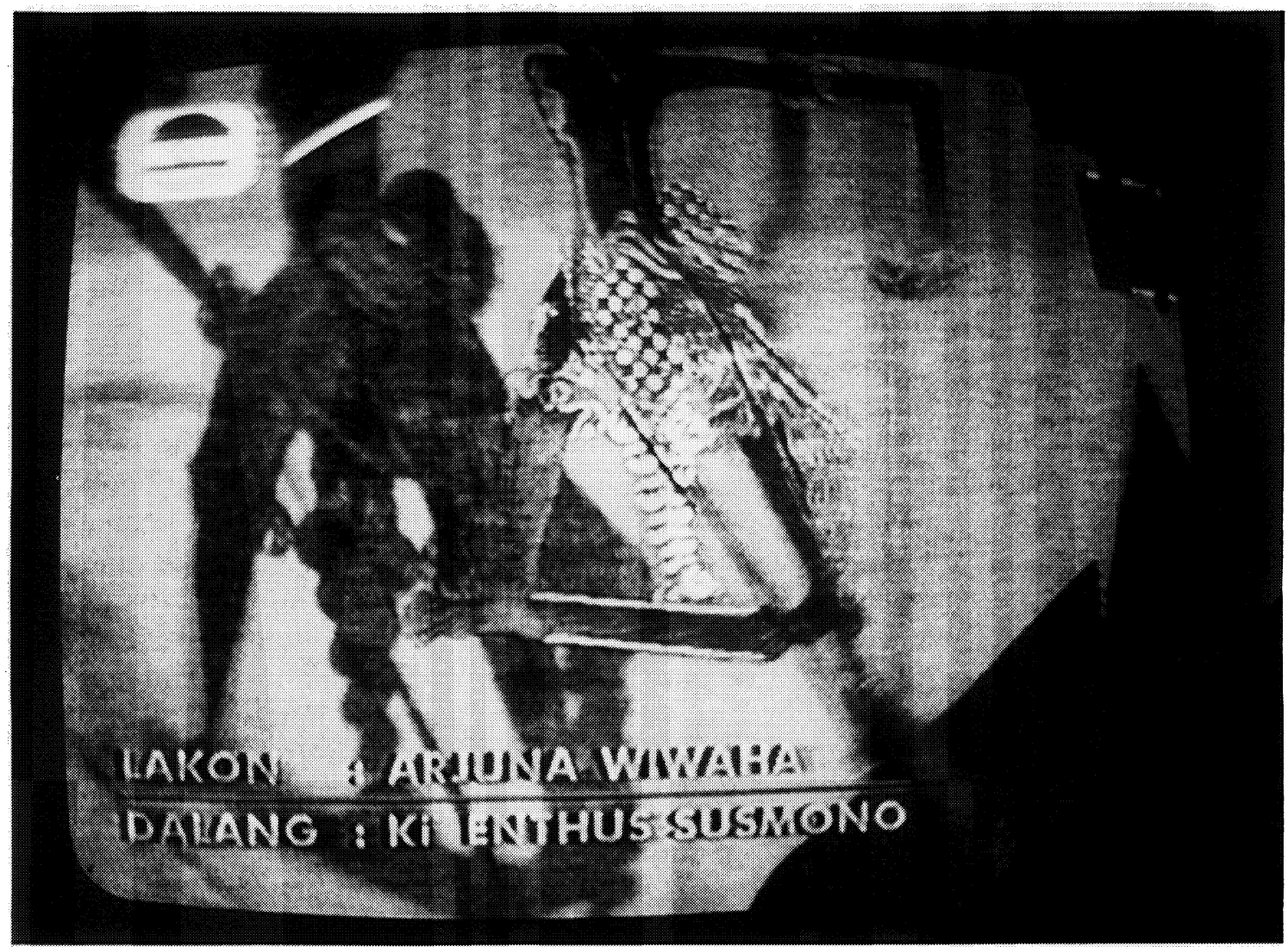

Figure 15

One could argue, as Umar Kayam might, that the technology serves to show wayang better. One can see how the movements of the camera try to reproduce the movement of the spectator's attention, paying most attention to those aspects of the performance that are thought to interest the audience. Thus, the cameras attend not only to the puppets and the screen, but grant at least as much time to shots of the pesindhens, and there are frequent momentary shots of the gamelan. Practically the whole time, the wayang is shown from the dhalang's side; on a TV broadcast, one rarely sees the shadows of the shadow puppets. However, this kind of "reproduction" results in an essentially different way of looking at wayang; or one might say that rather than looking at wayang and making sense of it, a spectator faced with a TV broadcast now looks at, and makes sense of, how TV "looks" at and makes sense of wayang. This is one aspect of the "marriage," of the way that wayang is "tuned" to TV: by using the different cameras and various visual, cinematic tricks, wayang is not merely shown. Instead, what is shown are TV techniques, TV effects-wayang exists somewhere between a state of being raw material and a state of being a partner in the "marriage."

TV affects wayang not only by the way TV presents it through the cameras; the wayang performance "before" the cameras is changed as well. I have mentioned how 
sabetan-visual movement-has become more important partly because of TV, and also noted how a particular kind of sabetan fits TV because in the beginning it was inspired by films-it focuses on fast, acrobatic movements of the puppets, rather than the physicality of the blows, the physicality of the puppeteer. The visuality of the new movements, like the visuality of TV, is less physical, less a matter of physical presencing, and more like pure movement of images, more "virtual."

Moreover, television producers have very specific demands. Wayang performances have been getting shorter, but they are especially short on TV. For instance, wayang on Indosiar begins around 11:30 or 12:00 at night, rather than the more usual 9 or $10 \mathrm{pm}$. Moreover, the TV producers at Indosiar ask that the dhalang dedicates significant time to the clown scenes, which now take about half of the total performance time (thirty to forty-five minutes for limbukan and an hour and a half to two hours for gara-gara is common). It is the TV producers who choose the "guest stars" whom the dhalang must accommodate. This is another way in which the authority of the dhalang is compromised. In 1996, Manteb, who had been the most popular dhalang featured on Indosiar, refused a contract for thirty more performances on Indosiar, citing as one of the reasons that the television station "asks this and that, which is often a difficulty for the dhalang"; 148 and in an interview, Manteb told me that producers "ask to have many attractions [atraksi]." Another reason for his decision to cancel was that he "fears that what is presented on TV will become the common measure"149—which is indeed happening. Younger dhalangs, including Warsena Slenk, Crazy Djoko, and Enthus Susmono, have been glad to take his place before the cameras. Apart from famous guest stars and beautiful pesindhens, TV-producers look for "daring" dhalangs, who do not hesitate, for instance, to stand up-a most radical action for a dhalangand box a (newly developed) "XL," a human-sized puppet of an ogre. In short, wayang on TV qua wayang is in different ways radically transformed by its being on TV; this transformed wayang has a great prestige because it is on TV; and thus it is imitated even in other wayang performances, or it helps to legitimize and give additional appeal to particular practices (usually innovations). The audiences expect it, and dhalangs know they can become popular if they present a performance that is like the TV performance. The growing importance of sabetan, as well as the further expansion of the clown scenes (both in time and in space), have to be seen in this light.

My point is to show that the "marriage" between TV and wayang has had a very profound, rather than superficial, impact on wayang performances, both those presented on TV and others; and that to speak of a "competition" between wayang and TV entertainment is not incorrect, but it fails to express how deeply wayang is involved with TV. Moreover, as in the case of the Campursari "marriage," this "marriage" is a matter of mixing wayang and the foreign ("global-modern," nonwayang, etc.), and of bringing, or admitting, the foreign into wayang. TV does not simply force itself on wayang, but dhalangs actively participate in getting wayang involved with TV, because they profit from the "marriage." Indeed, there is no question that TV helps not only individual dhalangs to become popular and successful, but it is also one of the factors in the rising popularity of wayang as a genre in recent years. On the other hand, as wayang "has to be ready to accept various eliminations and

148 Reported in Sarworo Sp, "Pergelaran Wayang Kulit di Televisi."

149 Ibid. 
additions of artistic-technical principles," there is a possibility, as one writer puts it succinctly, that "in the future wayang kulit will become only one of many animated cartoons." 150 This, in fact, is not merely a looming, future danger: wayang has already transformed itself profoundly so as to become essentially a part of TV programming, a part of the TV world, appearing next to sports (from which it borrows Mike Tyson and more), Chinese films (and it resembles them), Indian films (the dangdut music, inspired by Indian film music, is featured in the clown scenes in wayang and in other TV programs), cartoons (from which wayang learns new jokes and styles of representation), and Jurassic Park, which has inspired the extra-large puppets of a Javanese god, Betara Kala, and wayang-dinosaurs. Wayang is losing its old self in the "marriage" (as some people say) at the same time that it profits from the "marriage" (as others point out). And what is true about wayang as a medium is also true about the dhalangs: to many Indonesians, Manteb with his sabetan is known as the "advertisement star [bintang iklan]" in a TV commercial for a headache medicine, a commercial which, I heard, was selected as "the most popular TV commercial of the year" in Indonesia. (The commercial features Manteb somersaulting his puppets, seen from above-as it can be seen only on TV.) Or, if one is looking for symbols, I could point to the gunungan puppet used by Manteb and other TV-dhalangs in their Indosiar performances and now in other performances as well. This gunungan puppet, which serves, among other things, to symbolize the life and the universe (it is often glossed as "the tree of life"), now displays at its very center-where traditionally the Gate to Heaven would be shown-a large INDOSIAR logo (visible in figure 18, the gunungan puppet on the left), the same one that appears at the top left corner of the screen when wayang is shown on Indosiar (see also Figure 15, p. 110, or Figure 17, p. 122 ).

The quality of "TV-ness" itself, in its various manifestations, is an attraction in wayang. Television is a sign of modern technology, which is in turn associated with modernity in general, with the foreign, the "global," the "international." The symbolism of technology is not only a matter of discussions of televised wayang, but it plays a role in various aspects of the performance as well. Technology-electronic keyboards, wireless microphones, disco lights, dry ice, amplification systems, simultaneous television screening-is introduced not only for the theatrical effects that it brings about, but also because modern technology is itself an attraction qua modern technology, as a sign of cultural, social, and economic modernity. The television cameras, present at most large-scale performances, and the smaller video cameras at the more modest performances, are additional signs of modern technology and modern culture. Typically, it is not Indosiar (the television company), but the sponsor of the celebration (of which the performance is a part), who pays the performers, and the sponsor even often pays Indosiar to cover the performance, because, as an Indosiar producer put it, Indosiar's presence is a sign of prestige. The camera, like the microphones, keyboards, and so forth, is a part of the show and adds glamour to it. I have discussed how televisation helped give authority to and spread the innovations in wayang, and how these innovations often grow from imitations of other television programs, from wayang's attempts to become good television material. Like the modern technology introduced into wayang performance, including the cameras at the live performance, the characteristics of and references to television in televised wayang

150 Pamudji, "Ketika Panggung Ketoprak dan Wayang Diusung ke Televisi." 
are signs of modernity. Televisation of wayang is in part motivated by the association of television with modernity: one attraction of televised wayang is simply that it is televised, that it becomes television. It is rather like when in the Greek shadow-puppet theater performers wanted to "modernize" the performance: "Most kept the old hut unchanged, adding a television antenna to modernize it"; 151 or like when Javanese villagers write in big letters ISUZU on their locally made drums (Isuzu is the brandname of the Japanese drums that well-to-do musicians can afford); or like when a becak (rikshaw) driver puts a radio antenna, usually seen on taxicabs, on his becak.

The "marriage" between TV and wayang is only one example of wayang's opening to the present world, to the interaction with the foreign in the present world, and of the way that this opening, this involvement affects it. We have seen in this example that this opening and involvement affect not only the clown scenes, but also other parts of the performance, as well as the performance as a whole. In this sense, the whole wayang performance is becoming more like a clown scene, and not (only) superficially: it is now radically more open and involved in the present world.

To see how TV functions as only one of wayang's significant others, we can look briefly at the sources of Manteb's sabetan, for obviously, kungfu movies are not Manteb's only inspirations. Specifically, there is one dhalang, the late Ki Ganda Darsana, to whom Manteb is indebted for many of his "tricks," as Manteb says himself. (Manteb calls Ganda Darsana his "guru,"152 and he told me: "My sabetan was from the late Pak Darman [Ganda Darsana]. But Pak Darman was not as agile/frisky as I, because I spiced [my sabetan] with kungfu films, because I am a maniac when it comes to martial-arts films.") Ki Ganda Darsana, himself admired especially for sabetan, never attained the super-stardom of Manteb, Anom, or Nartosabdho, but he is respected and imitated by dhalangs. In the field of sabetan, he has had an influence comparable to Nartosabdho's influence in some other fields. What is relevant here, first, is that Ganda Darsana was a major influence on Manteb, and thus on the sabetan common today; and secondly, the uniqueness of Ganda Darsana's sabetan was inspired by his own long-term experience as a musician and actor (dancer) in kethoprak and wayang orang, and other musical and dance genres, many of them from East Java (such as reyog, ngremo, and others). As Edy Sulistyana, who is also a dhalang and student of Ganda Darsana, shows in detail in his thesis, many of the characteristic movements (as well as the shape of his puppets and the music) developed by Ganda Darsana and adopted by Manteb and other dhalangs, were imitations of specific dances and dance movements, and music and costumes from other dramatic genres. ${ }^{153}$ Thanks to Ganda Darsana, Manteb's sabetan, and the new sabetan today in general, bears marks of involvement with-and references to-not only TV, but also various traditional genres. How exactly wayang, and specifically sabetan, is involved with the other genres need not be examined here; the point is to remember that not only in the

151 Linda S. Myrsiades, The Karagiozis Heroic performance in Greek shadow theater (Hanover, NH: University Press of New England, 1988), p. 184.

152 Manteb quoted in Edy Sulistyana, Ki Ganda Darsana: Kehidupan dan Pengaruhnya Terhadap Perkembangan Pakeliran Sekarang (Surakarta: STSI, 1996), pp. 119-120.

153 See Edy Sulistyana, Ki Ganda Darsana. 
case of gara-gara, but in the case of dramatic techniques such as sabetan, wayang bears marks of its interaction with kethoprak, wayang orang, and other genres. ${ }^{154}$

Let me now reflect on some other areas of innovation. The reader should keep in mind that my examination is merely selective: only certain aspects of only certain innovations in only certain areas are discussed as examples.

I have discussed what happens in the clown scenes in two-screen performances earlier, and here I will only briefly comment on what happens beyond the clown scenes in these performances. I have mentioned that the setup makes the pesindhen, the guest stars, and the stage central, and sets the dhalangs aside. During much of the performance, only one screen is used, and the blencong on the other screen goes off. The dhalangs may alternate between scenes (one scene on the left, then another scene on the right). During the "movement moments," the action often remains on one screen, but occasionally the dhalangs try to collaborate by, for instance, more quickly alternating between the screens. In other cases (such as the "horse dance") both dhalangs perform at the same time and the blencongs on both screens are lighted. This collaboration is displayed in another way when, as sometimes happens, a character (or group of characters) on one screen (manipulated and given voice to by one dhalang) faces and talks to a character (or group of characters) on the other screen (manipulated and given voice to by the other dhalang), as in Figure 11. The simple bipolar composition that would be normally used for an equivalent scene-with the characters facing each other on a single screen-is here extended to the two screens: each pole is on one screen, and the bipolar composition, fitting the newly established symmetry, encompasses the whole stage. Each dhalang speaks the part of one character in the dialogue. In this sense, the dhalangs function very much like actors in kethoprak or in wayang orang, or like the comedians in the clown scenes (who often are actors from ketoprak or wayang orang); or like the actors in teater (Western-style theater).

A dramatic component that is traditionally closely related to the visual, even united with it, is the sound effects. Traditional sound effects (keprakan, dhodhogan, drumming) ${ }^{155}$ continue to be used and continue to be essential, but new ones are being added. In the 1970s, Manteb first added Western-style cymbal and large drums to further enforce the traditional sound effects; in this case too, he was not the first to do that, but he popularized the practice. Traditional sound effects are closely related to and support puppet movements, and the new sound effects as well are inseparable from Manteb's innovation in puppet movement. The loud crashes of the cymbals and of the large drum fit the feeling of the flashy, acrobatic movements, so that Manteb's "sabetan full of dramatic liveliness becomes more lively/alive [hidup] when it is supported by other [i.e., non-gamelan] music instruments." 156 In the early 1980s, Manteb introduced "realistic" sound effects, such as the sound of flying arrow, sound of fire, water, and so on. These sounds are made on the keyboard, which was first popularly incorporated into the wayang performance in this capacity. But it is important to point out that these sounds are "realistic" in a special way. Manteb told

\footnotetext{
154 Manteb has also acted in kethoprak in the past, and he became very active in televised kethoprak in 1998 and especially 1999.

155 For a discussion of these, see Mrázek, "Phenomenology of a Puppet Theater," Chapter Four, Part Two.

156 Komar Abbas and Seno Subro, Ki Manteb "Dalang Setan," p. 99.
} 
me that his innovations were criticized because, for instance, the sound effect that he uses for flying arrow is not really like the sound of a flying arrow-it is only in films that an arrow makes such a sound, his critic said. Speaking to me, Manteb countered in this way: "Is the sound of dhodhogan [the rapping traditionally accompanying the flying arrow in wayang] like the sound of the arrow?" The point is: the "realistic" sound effects are called "realistic," but by that it is not meant that they are more realistic than wayang sound effects; rather, they are heard as the sound effects from other media, especially film and television, so that listeners recognize, correctly, that they are merely conventional. Manteb points out to his critic that traditionally in wayang, too, the sound effects are conventional, and therefore there is nothing wrong with using conventional sound effects from another medium. Thus, the new sound effects are not understood simply as formal developments (which they also are, and they are used in conjunction with the traditional sound effects; and they also fit with music very much like traditional sound effects), but they are also interesting because, rather like the keyboard on which they are produced, they are foreign, specifically, because they, like Manteb's sabetan, are inspired by film.

In this case, as in other cases, younger dhalangs go further than Manteb. While Manteb uses the sound of a triangle when two metal weapons clash, Enthus Susmono uses the sample of the sound of a triangle reproduced by keyboard, but, for comic and TV-cartoon-like effect, the pitch of the sound changes as different parts of the metal weapon are hit, so that in the end the characters on the screen are puzzled and "play" on their weapons as on musical instruments, producing different pitches. The conventionality of the sound effect-the fact that it is only artificially connected to visual movement-is brought out and played with; that is, rather than being unified with the visual action, the sound effects are juxtaposed against it and rendered incongruent with it in a funny way .

This leads us to another area of developments: dramatic music. Nartosabdho and Ganda Darsana have both introduced various musical innovations into their performances, and many of these have been taken over by dhalangs performing today. New melodies for srepegan ${ }^{157}$ used by most dhalangs today, for instance, are associated with Ganda Darsana, and he is assumed to be the composer. The traditional version of srepegan pathet nem, for example (which is still common today next to Ganda Darsana's new versions), and the Ganda Darsana's version compare thus: ${ }^{158}$
Traditional:
(2)3232356(5)6565235(3)535352351653653(2) etc.
Ganda Darsana:
(2) $16 \underline{32356(5) 653256 \underline{(3)} 231652351653653(2)}$

I have underlined those notes that are same in both versions. The structurally significant beats (especially beats marked by the gong, here in parentheses) are the same in both versions, as is the basic gong structure (the musical form); the difference is a matter of details and of melodic style. Ganda Darsana's version is less formulaic, somewhat less predictable. For instance, instead of the upper-lower-upper-lower contour after each gong-e.g., 3232 after gong 2, or 6565 after gong 5-which is, with

157 Srepegan is a highly versatile piece and it is played many times in each performance.

158 The number-notation, commonly used today, represents tones of a Javanese scale. 
rare exceptions, the standard feature of Solonese srepegan, ${ }^{159}$ Ganda Darsana's version uses a different, unpredictable, more melodic melody, if I may put it that way. Ganda Darsana's srepegan is made musically more interesting: there is more attention to what is happening in music itself (not in music in relation to drama), because the music is less predictable and calls attention to itself; it is presented as new, as interesting. This kind of innovation is quite subtle, but, as we shall see, in its character it anticipates more radical innovations in music.

Let me look at another subtle musical innovation, attributed this time to Nartosabdho, and let me focus on a particular example. Traditionally, the first, repetitive, minimally melodic part of Ladrang Diradameta is repeated when the puppets are moved, and the music continues to the next, higher, and more melodic part only when the puppets are set in a pictorial composition and the dhalang is going to narrate, while the gamelan plays softly the more melodic part. In Nartosabdho's performances, however, the first, minimally melodic part is not repeated (or it is repeated only once), the music goes into the higher, melodic part sooner, while the puppeteer still moves the puppets, and the more melodic part is played in full volume and with both pesindhens and the male chorus (gerong) singing. As Pak Naryo explained, Nartosabdho had the more melodic part performed sooner and in full volume because, "as always," Nartosabdho wanted to give the vocal part more prominence in that piece. Traditionally, the male chorus, for example, would sing only in the more melodic section, and if this part only accompanies the dhalang's narration in reduced instrumentation, as it does traditionally, the gerong would not be likely not to sing at all in this piece. Of course, traditionally, the gerong may not be even present; again it was Nartosabdho who made it popular, and his version of Diradameta is a product of the same process. Furthermore, when Nartosabdho privileges and foregrounds the singing, he compromises the dramatic function of music, for as Pak Naryo pointed out to me, Nartosabdho must postpone the narration until the singers are through with their vocal part, that is, until the end of the melodic section; or, he might narrate as the singers sing, which again compromises the dramatic function of music. In short, Nartosabdho prefers to adjust the other dramatic components to music: music, specifically singing, comes first, drama second. This innovation, too, is more subtle than may seem from my description, but I have tried to illustrate a basic characteristic that it shares in common with Ganda Darsana's innovations, discussed above: when music is privileged, the relationship between music and other dramatic elements is compromised.

We have seen that the various ways in which the clown scenes have expanded-in time, by the inclusion of dialogues between the dhalang and the pesindhen, and later by the addition of comedians-were at different stages closely related to the growing prominence of non-dramatic music, singers, and songs. Now we see that dramatic music is becoming less dramatic, that is, more like non-dramatic music, that is, more like the music in the clown scenes. Thus, musically, too, the whole performance is becoming more like the clown scenes-a presentation of separate attractions.

${ }^{159}$ See Alton and Judith Becker, "A Grammar of the Musical Genre Srepegan," Journal of Music Theory 23 (1979):1-43. 
The above examples are only the first signs of this. The singing style for the suluk ("mood songs" traditionally sung by the dhalang) prevalent today-associated especially with Anom (people say that everybody sings like Anom, and moves puppets like Manteb) -is more ornate and is meant to impress the audience with the beauty and strength of the dhalang's voice. But, as critics point out, this new emphasis on virtuosity renders the dramatic expressiveness of the mood songs secondary. According to these critics, the new style of mood songs more and more resembles the pesindhen's vocal part. In fact, it is now common for the pesindhen to sing some of the mood songs - for the sake of musical variety and to show off the pesindhen - and often these are turned into, "treated" as, or replaced by, pesindhen-style melodic patterns. Often, the instrumentation of the mood songs is replaced by a sexier instrumentation with a greater number of instruments and lively drumming, such as that used in palaran or jineman. Indeed, the appeal of music and the appeal of the female singer are difficult to separate and are similar in nature. Also, Nartosabdho's and Ganda Darsana's musical innovations have been taken over by dhalangs performing today. Manteb especially has been learning from these two dhalangs- he cites both as his teachers, as does Anom-and he has gone further-in this respect, Anom is said to imitate Manteb's innovations. He uses many new compositions in the dramatic sections, many of which are composed by or in collaboration with Subono, a dhalang at STSI (Indonesian College of Art). Dramatic music in wayang is becoming more and more interesting musically, rather than dramatically: more melodic, with much more focus on vocal parts. Musical pieces and musical elements (such as drumming, or various instruments) from other regions have been incorporated into the dramatic repertoire; this too makes music more interesting, so that music becomes more and more an independent attraction, rather like the person of the pesindhen. ${ }^{160}$ Puppet dances-of course closely related to music-often stand out and have become sometimes very long, and they too have become, much more than before, independent attractions-one character may dance to musical compositions from different regions of Java combined into a single long dance composition (this is true about performances by dhalangs of Manteb's and Anom's generation, but it is developed much further in performances by some younger dhalangs, such as Enthus). As a result of such developments, musicians now have to rehearse new pieces, the order of pieces, or the order of dance/drum patterns, and the whole performance is more precomposed. The dhalang prepares for the performance, often with musical advisors, and during the performance he is less free to build the performance and improvise, for he must adhere to the agreements made at the rehearsal. Thus, he has somewhat less freedom to order the musicians in the performance. In this respect too, the dramatic parts of the performance are more

160 However, there are some interesting and effective dramatic-musical developments as well, and many of these elaborate on existing dramatic-musical principles or techniques. For instance, dramatic tension and acuteness is traditionally enhanced by the appropriate density of punctuating gongs (the higher the density, the tenser the dramatic situation). Ganda Darsana has popularized the practice of playing a particular piece, srepegan, in a tempo twice as slow than had been usual, in addition to playing it in the usual tempo, which makes possible a greater variability of dramatic-musical tension and atmosphere (even within one piece). This practice is common today. Similarly, Manteb uses new pieces that are felt as tenser than the tensest traditional dramatic-musical form (sampak), again by increasing the density of gongs, now in different way, and by making the pieces even more repetitive (and less melodic) that sampak (in this case, the gong suwukan sounds every fourth beat-the pitch 2 -of an extremely repetitive melody: 26662666266626662 etc.). 
like today's clown scenes in that the dhalang has to share his authority with other people.

This indeed is the common characteristic we find in the examination of innovation in the different areas of the performance, apart from the clown scenes: the innovations outside the clown scenes are making the whole performance grow more like the clown scenes. That is, the clown scenes are not only expanding in time, and in their opening to the outside; their characteristics, their clown-scene-ness, are also penetrating the whole performance.

I have mentioned that some dhalangs, such as Warsena Slenk, use disco lights during the clown scenes. Furthermore, many dhalangs use colored lights in other parts of the performance, especially in the "movement-moments," for dramatic purposes. The white light of the electric blencong may be replaced by red, yellow, or blue light, as well as by flashes resembling the photographic flashes, to enhance battle scenes, the representation of a marching army, the representation of a character flying, and so on. If one were writing a history of lighting in wayang, one would have to see this in relation to the dramatic, almost musical, possibilities of the oil blencong, and to the elimination of the blencong when electric light began to be used. As I have mentioned previously, old dhalangs tell that the flame of the lamp was adjusted to suit the dramatic situation. There is more to say about the new ways of playing with light; but here suffice to say that one important inspiration is teater, or Western style theaterwhich is very much foreign to most wayang spectators-and that the colored lights were first used in various experimental performances created in the arts academies in Yogya and Solo. One key figure in the experiments, for instance, was Sukasman, a Yogyanese artist, graduate of the Academy of Fine Arts in Yogya, who has begun his experiments after his "experiences roaming over Europe for about ten years," and a stay in New York "gave him courage." 161 His wayang used various colored lamps, more than one screen, dancers, mixed gamelan and non-gamelan instruments, and special translucent puppets. Similar "experiments" were being conducted in the Solonese academy of the arts in the $1980 \mathrm{~s}^{162}$ Manteb and other dhalangs were familiar with both, and contributed to making some of the elements common features in wayang performances. ${ }^{163}$

While Manteb has played an important role in the popularization of various innovations (especially in the 1980s to mid '90s), younger dhalangs go further in their incorporation of the (for most Javanese) obscure techniques from teater into wayang. Enthus Susmono, perhaps the most radical young dhalang popular today, who has worked as a radio broadcaster, was involved with ketoprak and was the music: arranger for a teater, uses not only colored lights, but also dry ice and spotlights, and is said to use "the concept of teater in his performances." 164 Crazy Djoko also told me he learns from teater. Techniques from teater, as well as the concept of teater-and these

161 Bambang Bujono, "Wayang transparan, wayang bewarna," Tempo, July 13, 1985, p. 28.

162 For many technical details and a history of the project, see Bambang Murtiyoso, "Mengenal karya baru wayang layar lebar Sandosa," Gatra 1988, No. 18 , pp. 19-20, 30; for a short analysis of the experiments, and Manteb's role in the popularization of some of the techniques, see Sears, Shadows of Empire, Chapter 5.

163 Manteb actually uses certain puppets made by Sukasman, and he has a close connection with the Solonese academy, being officially an instructor and having performed in the experimental wayangs there.

164 Apa \& Siapa Orang Jawa, Edisi 1995-1996, pp. 302-03. 
are more ostentatiously radically foreign than TV-have been for some time (at least since the eighties) present in wayang. In some cases, elements of teater are incorporated into the dramatic techniques of wayang-sometimes well, sometimes not, depending especially on the talents of the dhalang, and thus they are made more or less "at home" in wayang, and may become somewhat less foreign and more integrated with other dramatic techniques. However, they are also displayed for what they are, in their foreignness, and that is an aspect of their appeal. This is clear from the reaction of the audience, especially in the more radical performances, such as those of Enthus (Manteb is much more subtle, or "less daring," in the ways he uses colored lights, than Enthus). In a performance by Enthus, the appearances of dry ice smoke and various colored moving lights are typically met with surprised laughter, and then applause. Most people do not see them in relation to the dramatic situation, or they do not see them primarily so; they see them as an additional attraction, as a daring departure from wayang techniques. In a book on Manteb by his associates, based on a series of interviews with Manteb:

$\mathrm{Ki}$ Manteb knows that the intention of young dhalangs is to make wayang into modern drama [drama modern] or teater. If needed, the dhalang becomes a wayang [i.e., a character]. If needed, the dhalang will rape the pesindhen. Ki Manteb understands what is the intention of young dhalangs, who want anything as long as it is new [asal baru], as long as it is crazy [asal edan], as long as the spectators clap hands. Thus, the wayang performance will collapse, break down [bubrah bin rusak]. 165

Manteb told me that development does not mean that "the dhalang jumps up and down, and the female singer stands up, naked if need be." For Manteb, like for most wayang viewers and dhalangs, teater and "modern drama," and their incorporation into wayang, especially when it goes too far, is essentially crazy, like raping a pesindhen on the stage: the performance is made new and crazy for the sake of newness and craziness ("asal baru" "asal edan"), and because it makes spectators clap hands.

That wayang is becoming crazy (edan) is common knowledge now. Not only critics, but the popular younger dhalangs themselves and their fans agree on that. But what is important is that it is consciously and intentionally made so, that the craziness contributes to wayang's appeal. Crazy Djoko (Djoko Edan) is one of the most popular dhalangs of the nineties, the model followed by many smaller dhalangs. He popularized the practice of having singers and comedians stand up, and he is famous for his pop and rock songs. "Strangely, he accepts the title crazy dhalang [dhalang edan] with pride. For he sought and struggled [diperjuangkan] for that adjective for many years." 166 At the end of the first clown scene, he usually advertises the second clown scene as being full edan, "fully crazy" (full comes from "full AC [air conditioning]" on busses: "full" is often understood as "complete with..."; there are now also busses advertising full music and full toilet).

What is this craziness and whence its appeal? Craziness, the not-normal, can be seen as another aspect of the foreign, and the mixing of the foreign with wayang; and the popularity of "crazy dhalangs" (Ki Nartosabdho, by the way, was also called

165 A. Komar Abbas and Seno Subro, Ki Manteb “Dalang Setan," p. 148.

166 Apa \& Siapa Orang Jawa, Edisi 1995-1996, p. 52. 
dhalang edan) reflects the enjoyment of seeing the breakdown of rules, or relations, of the structure of wayang performance. But this has to be also understood as an important aspect of the expansion of the clown scenes. The clown-servants are traditionally somewhat crazy, like the Elizabethan "fool," and their jokes are a manifestation of their craziness; their master, in fact, when one of the servants makes a more pointed joke, calls them crazy (edan) when he says "Wong edan ora tata!" (translated literally: "Crazy man, no rules/order!"). This is a standard formulaic expression in wayang. That the whole performance-including the dhalang-is ostentatiously crazy thus has to be seen as an aspect of the whole performance becoming more like a clown scene and the dhalang more like a clown. Furthermore, remembering that clowns are characterized by (as A. L. Becker puts it) "using modern language, modern ideas, and modern behavior," we can see that the performance's tendency to become crazy is directly related to the increasing opening of wayang to the present, "modern," world, because in wayang the contemporary, the "modern"-as introduced by the clowns-is, traditionally, crazy.

Related to this is perhaps the most important development in wayang performance. One of the most frequent observations by Javanese observers is that the whole wayang performance is becoming comedy. In many performances, humor is now more central in all parts and aspects of the performance. According to one Javanese, "from the first audience scene to the tanceb kayon [the end], there is only comedy [anane mung dhagelan]."167 Pak Naryo said about Ganda Darsana, the precursor of many of the current trends, that his puppet movements are exemplary, but "what is strange, the puppets/characters are all clowning [anehe, wayange ndhagel kabeh]."

On one level, it is obvious how this relates to our previous conclusions: if the whole wayang performance is becoming comedy, and all the characters clowns, then the whole performance is becoming like the clown scenes.

But the question that offers itself, and that we have not discussed above, is this: how do comedy and humor relate to the other characteristics of the clown scenes, which, as we see now, are also the characteristics of prevalent innovations in the dramatic parts of the performance? Comedy closely relates to the fascination with the foreign, and the mixing-in of the foreign. Many jokes in wayang work by juxtaposing two things that one would not expect to be juxtaposed, or by saying or doing a thing in a context where one would not expect it. In many cases, this is a matter of the sudden breaking of the performance's frame of reference, such as when Kurawa's prime minister Sengkuni plots an attack on the Pandhawa and one of the Kurawa states that Sengkuni's plan will fail like all others, for: "What kind of dhalang would it be who would let the Kurawa win?" Or, we can cite an example when one character says to another something to the effect "only you can save us, it's all up to you," and the other character (such as Kresna) counters, "no, its up to the dhalang." This kind of joke is popular in many variations, as is the following visual one: two characters fight and as the fight gets increasingly excited, suddenly the characters leave the screen and are fighting on the floor near the dhalang or above the puppet box. Or: as Cakil, after being killed, falls down on the ground, he suddenly stands up again, saying, "hey-an ant!" and moves to another place, betraying that he is not the real dying Cakil, but only an

${ }^{167}$ Quoted in “Pedhalangan Wis Rusak,” Mekar Sari, September 6, 1996. 
actor (even though he is only a puppet). Such jokes bring in the unexpected, they bring in a point of view-only a glimpse from a point of view-as if from the outside of the represented world. This point of view is foreign to the point of view established by the representation (which does not mean that these kinds of jokes were not used in wayang for a long time). The outside, and the new point of view presented in an unexpected way, is a matter of bringing in the foreign for a moment. Teguh, a founding father of the popular Sri Mulat comic theater (now a hit on TV), had the following "recipe" for comedy: "The funny is strange, the strange is funny." His major inspirations included Charlie Chaplin and the clowns from wayang. ${ }^{168}$ Sometimes one has even the feeling that the traditional point of view, the traditional frame of reference, or the setting of the represented world apart and at a mythical distance, are there now merely in order to be broken or breached for the sake of making a joke. Sometimes one has the feeling that the princes and gods are there only to become clowns.

This kind of unexpected juxtaposition of two things or points of view, a juxtaposition that lies at the core of the jokes, is in many other jokes also a juxtaposition of the modern to the traditional, or a matter of bringing the modern into the traditional. For instance, Mike Tyson, the American heavy-weight boxer, has been a celebrity in Indonesia for a long time. A number of dhalangs (including Crazy Djoko and Enthus) have puppets representing Tyson, and this Tyson dance-boxes to the accompaniment of disco beat and TV-cartoon-like sound-effects and presences movements characteristic of the American Tyson, especially a characteristic nervous head-shake (see Figure 16). When in the summer 1997 Mike Tyson bit off a piece of his opponent's ear in a boxing match, dhalangs used the particular episode, or reference to it, as well. For instance, before a battle one character would ask the other "Do you dare to fight with me?" and the other would say, "Is ear-biting allowed?" These jokes are of course a part of a long tradition of representing motorcycles, police cars, helicopters, Chinese people (see Figure 17), Dutch tourists, and other kinds of foreignness in wayang. One kind of the foreign (non-traditional, non-Javanese, etc.) here coincides with another (and unexpected glimpse from a strange point of view), and the two are brought into and presented in wayang for comic effect. The non-wayang, cartoon-style of representation of the new comic puppets is another kind of comic foreignness. Here it becomes obvious why people often laugh at the moment they see moving colored lights in wayang: when the foreign, the new technology, unexpectedly makes itself visible in wayang it is at first funny. This is like what happens in so many contemporary clown scenes-for this is a cherished joke-when the clowns are seen sniffing around as if something smelled "real bad," and then the ever-so-refined Prince Arjuna admits shyly, quietly: "It was me."

\footnotetext{
168 See the chapter entitled "Lucu itu aneh-aneh itu lucu ["The funny is strange, the strange is funny"]" in Herry Gendut Janarto, Teguh Srimulat: Berpacu dalam Komedi and Melodi (Jakarta: Gramedia 1990), pp. 158ff. See also James T. Siegel, Solo in the New Order: Language and Hierarchy in an Indonesian City (Princeton: Princeton University Press, 1986), pp. 87-116.
} 
122 Jan Mrázek

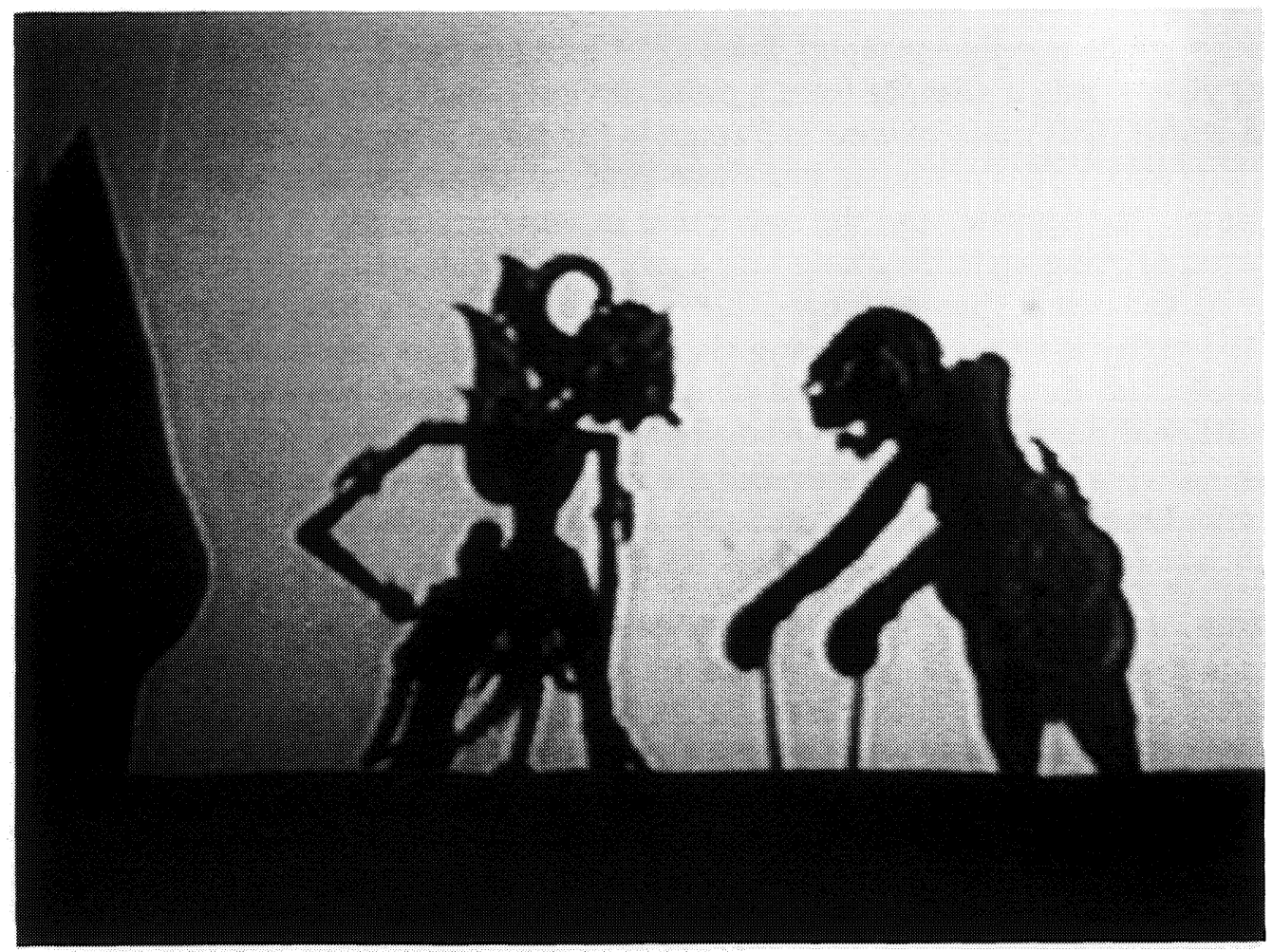

Figure 16



Figure 17 
For farting, like modern technology and modern behavior, like teater and disco, is a matter of the present world. It is the clowns (in particular Semar) who are traditionally characterized by "persistent uncontrollable farting" (to borrow Ben Anderson's expression). ${ }^{169}$ That is: it is again important to remember that the clowns-the main exponents of the jokes-are themselves as if from the outside of the represented, mythical world ("clowns, using modern language, modern ideas, and modern behavior, [and persistently farting] step among the heroes and demons and gods like wideawake men in a dreamworld"). Their being from the outside, this degree of foreignness to the heroes' way of being, is itself essentially comical, it is a joke that comes before any other jokes that the clowns may make. According to Teguh, even the shape of the clowns is strange, ${ }^{170}$ and as people often point out, even merely the first glance of the clown-puppets makes you laugh.

Now, the situation is more complicated, because all the characters are becoming to some extent clowns, that is, the characters are more and more outside themselves, foreign to themselves in the way that clowns are traditionally foreign to them, which, in the context of what wayang represents, means, as the spectator quoted at the head of this essay put it, all the characters are crazy. In various specific cases of jokes, this foreignness-to-themselves, this being modern in a mythical world, is manifested in different ways. It happens when one of the princes rides a motorcycle or a police car (Figure 18); when another prince bribes the enemy so that he can avoid fighting (corruption being very much a matter of the present world); when a military plane flies across the screen, and a paratrooper is seen falling on a naked, bathing pesindhen ("Hey, there is a pesindhen taking a bath!" cries out the paratrooper; see Figure 19); or when during the golek dance ${ }^{171}$ at the end of the performance the golek-puppet-dancer goes to pee (which is what many of the performers, and especially the dhalang, are about to do after the end of the all-night performance). A (perhaps less important) manifestation of making all characters strange, crazy, and thus funny is the profusion of new puppets representing various kinds of spooks and ghosts that are traditionally comical (in addition to being possibly something else), as well as foreigners (such as the Chinese Begawan Lie Ceng Swe [Figure 17, p. 122], "Dutch" tourists, etc.), funnybecause-strange ghosts (Figure 20); foreign-looking musicians playing non-gamelan, Western instruments (Figure 21); and many new, funnier and stranger versions of the clown-puppets (Figure 22).

I should emphasize again that these jokes are not "totally" new-comedy in general, like innovation, is traditionally an important aspect of the performance, and a dhalang's ability to make jokes is considered very important-but what is new, what is felt as new, is that comedy is becoming central to the performance, that it so much dominates the performance, that even the illustrious prince Arjuna farts.

\footnotetext{
169 Benedict R. O'G. Anderson, Mythology and the Tolerance of the Javanese (Ithaca, NY: Cornell Modern Indonesia Project, 1965), p. 23. See also Crazy Djoko's description of a clown scene, cited at the beginning of this essay, in which Semar's son Bagong scares Prince Bima, Arjuna's brother, with a fart.

${ }^{170}$ Janarto, Teguh Srimulat, p. 159.

${ }^{171}$ Golek is the rod-puppet that is used to represent the female dancer, but "golek" also means to "search, look for," and the golek dance-presented after the shadow-puppet performance is over-is often interpreted as a symbolic cue for the audience to "search"-golek-for the hidden meanings of the performance.
} 
124 Jan Mrázek

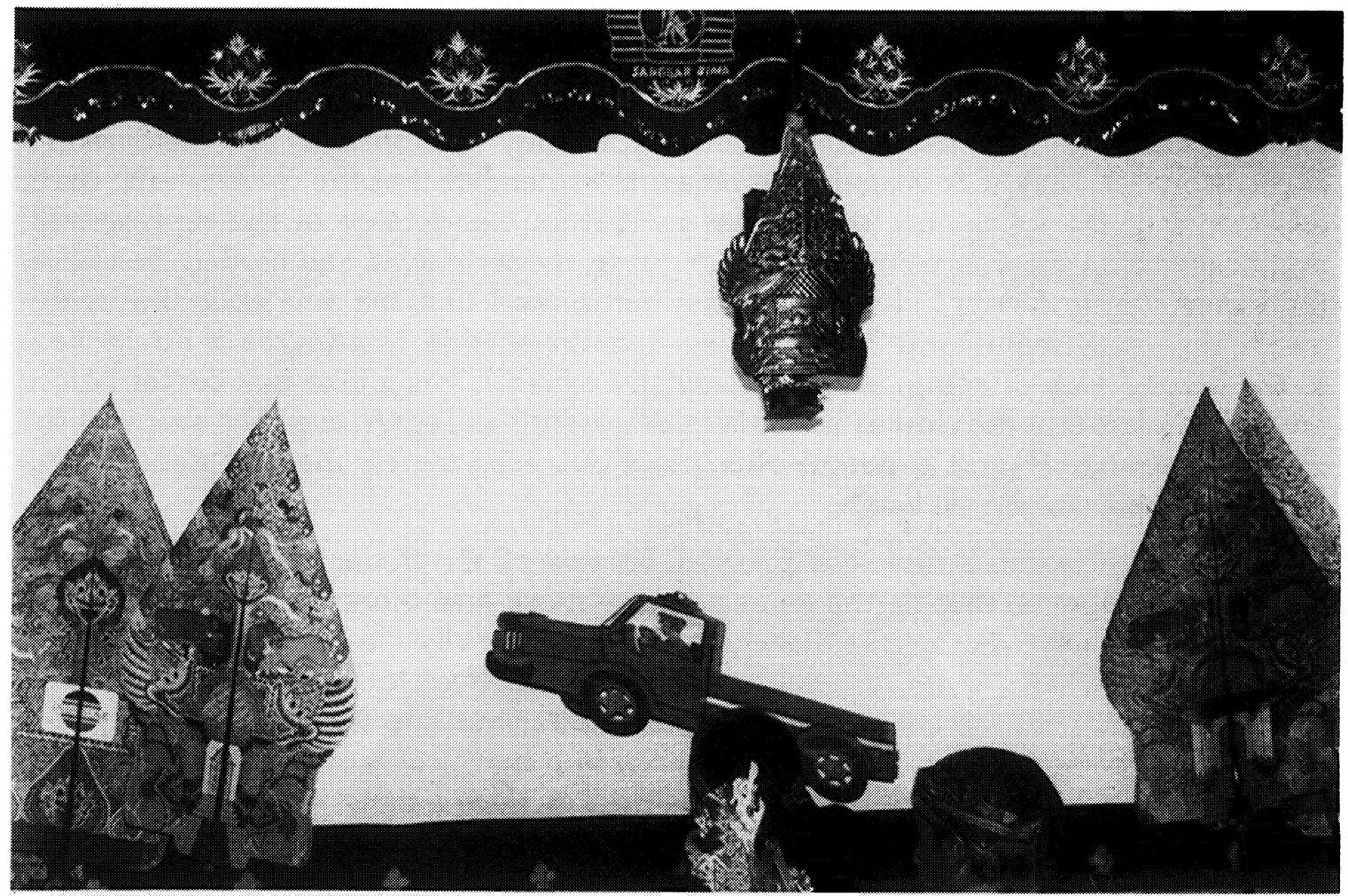

Figure 18

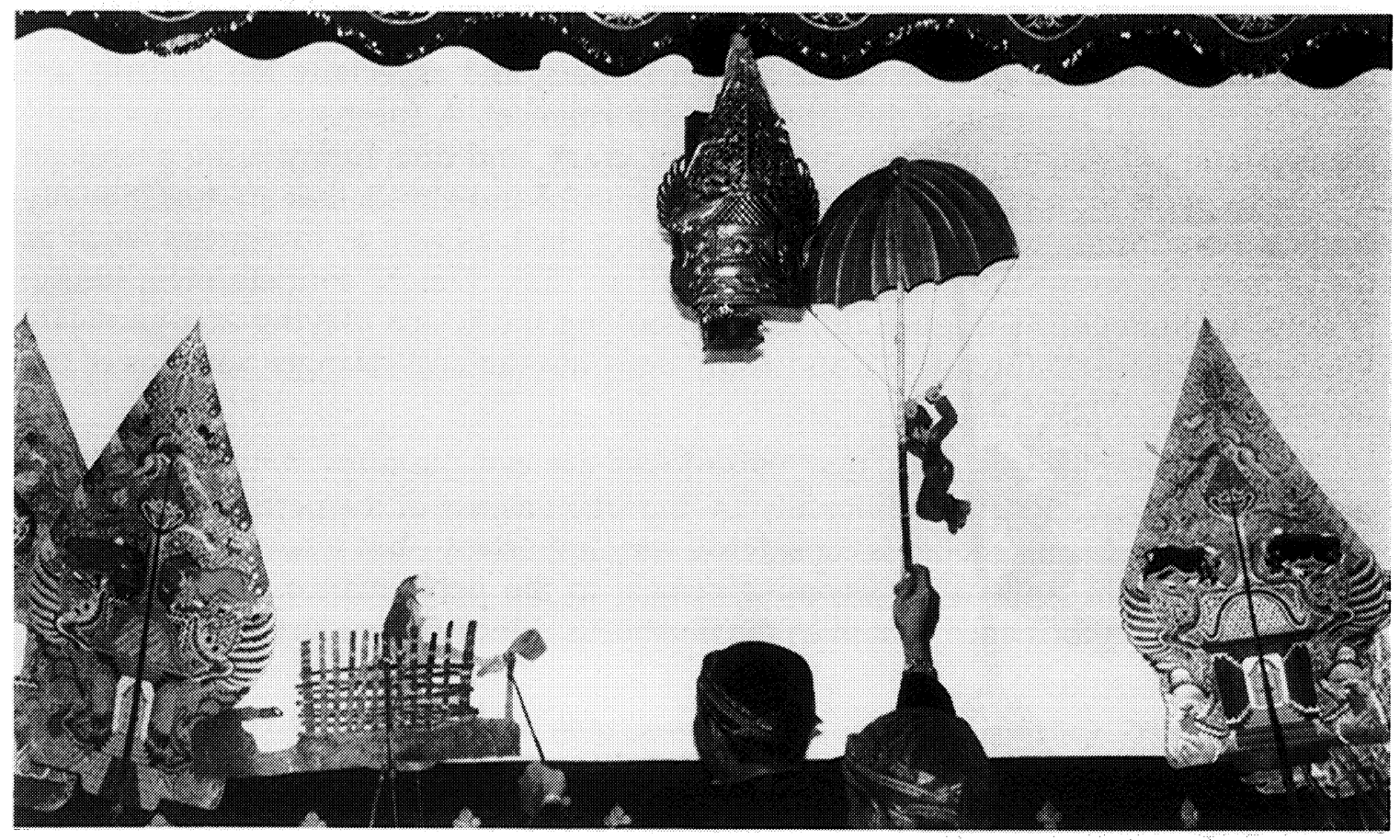

Figure 19 


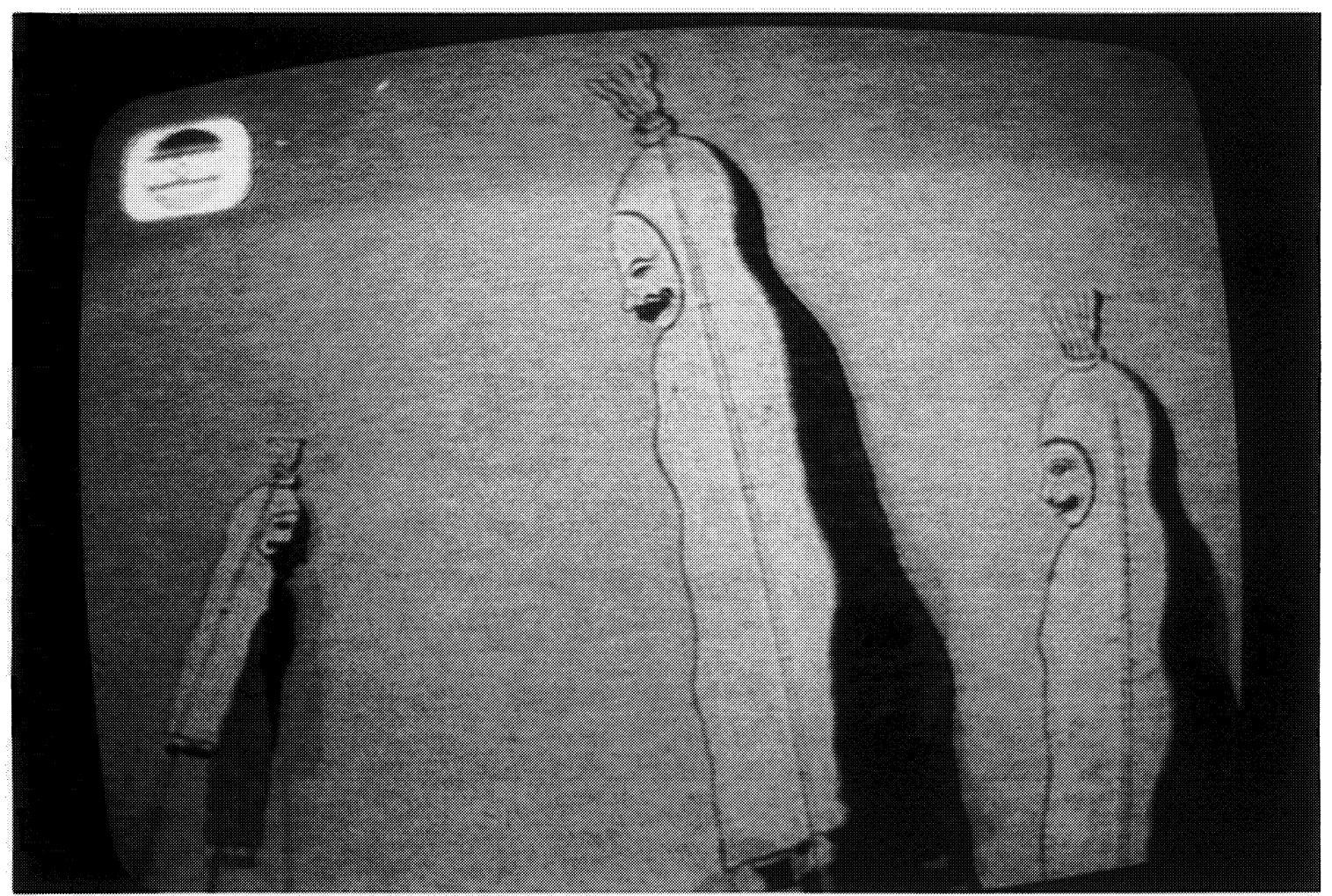

Figure 20

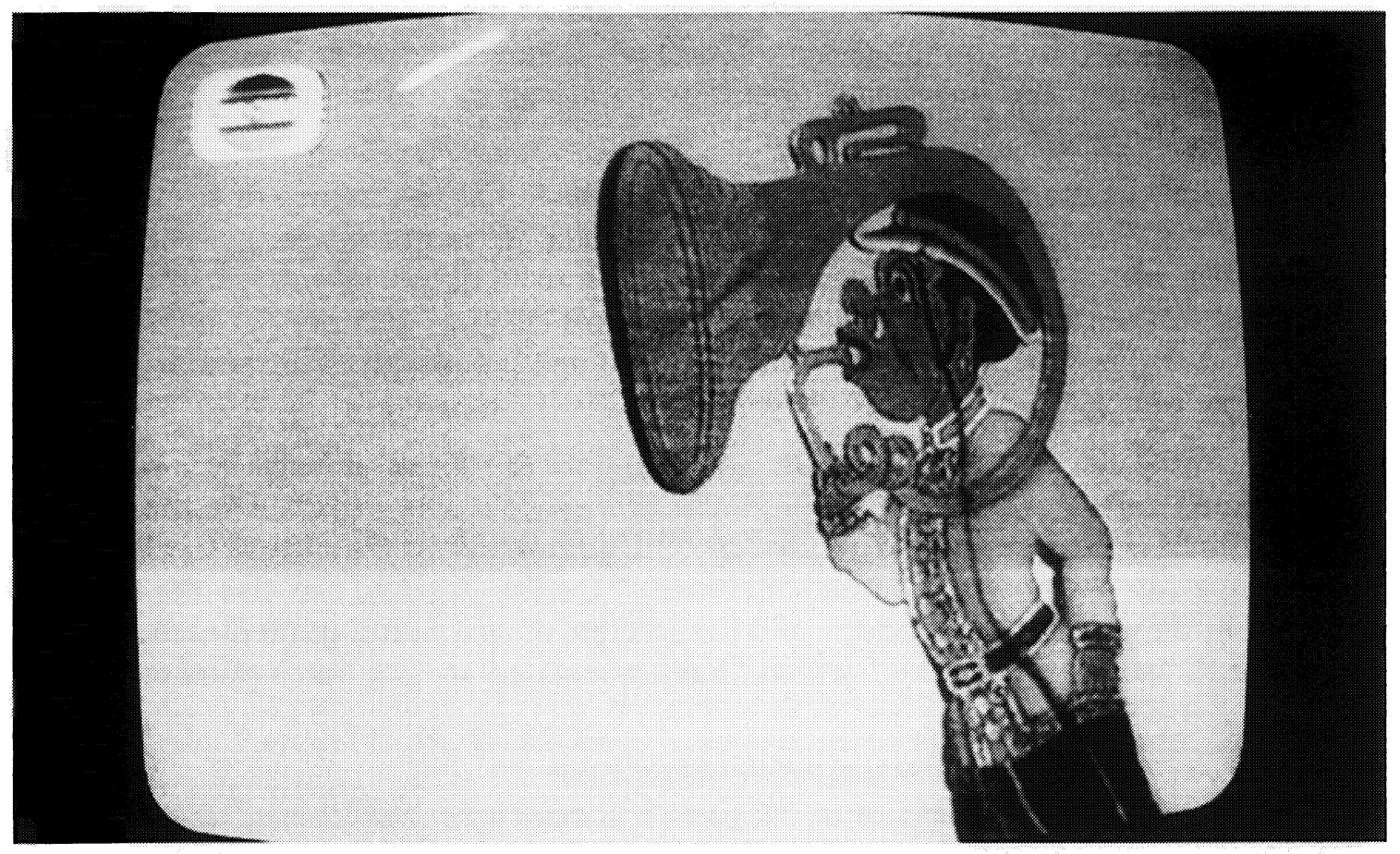

Figure 21 


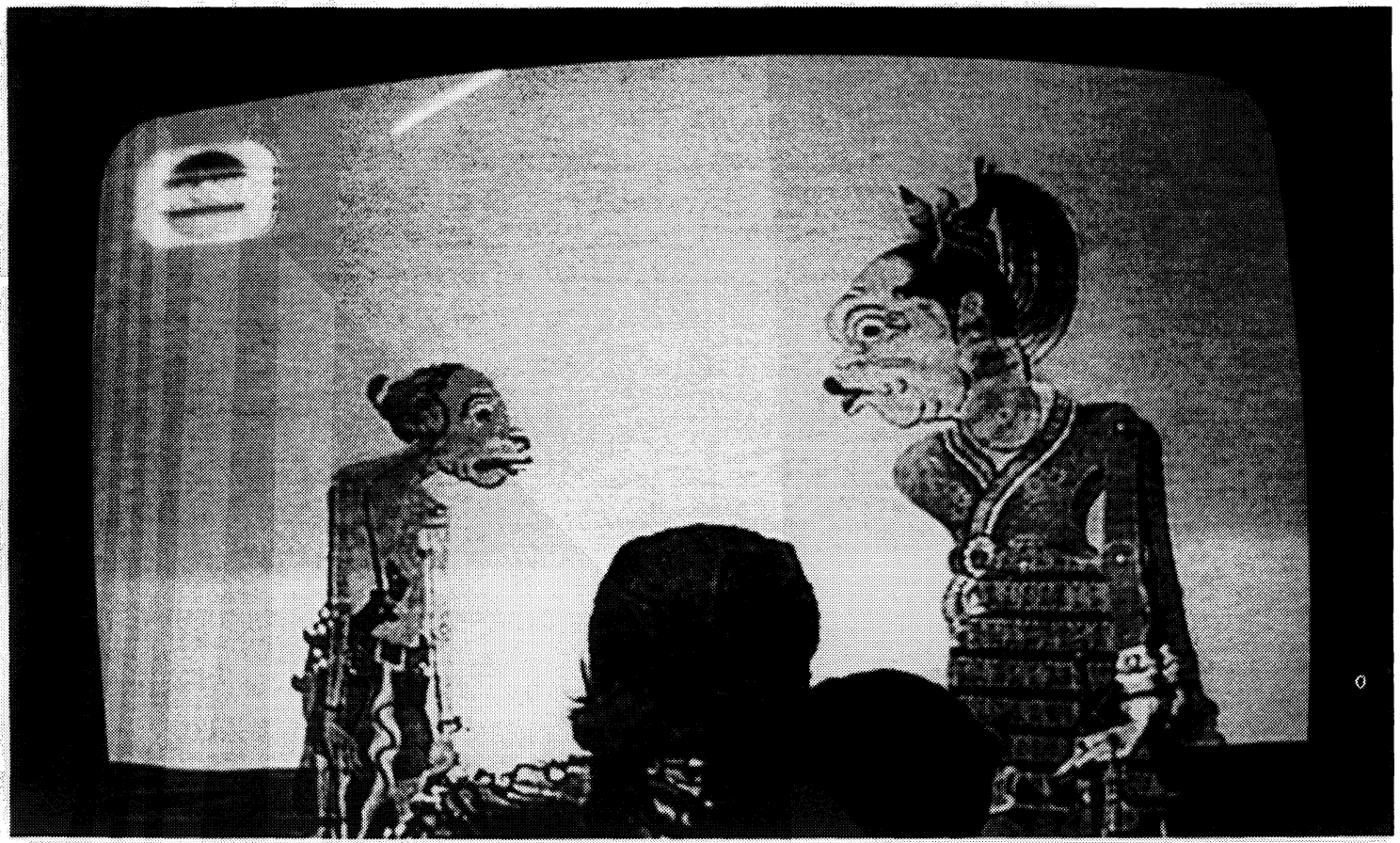

Figure 22

The discussion above shows, in one way, how the emphasis on humor is an aspect of the increasing opening of the clown scenes and of the performance as a whole to interaction with the contemporary outside. A Javanese writer, I might mention, connects humor to the increasing opening of wayang in a different way, or at least suggests that there is a connection:

It has gotten so far that the wayang performance has the nature of comedy, and almost more than two hours are full of alternating humorous songs. The form of the wayang performance is becoming a light-music concert [klenengan gobyog], and the story of the wayang drowns in the mud of cultural decline. For indeed these are the times of comedy [kini memang zaman dagelan]. The content of the performance itself is full of comedy. ${ }^{172}$

Wayang is full of comedy because "indeed these are the times of comedy." Wayang's becoming a comedy is presented as a matter of wayang's opening itself to the present world, which is characterized by comedy. ${ }^{173}$ Understanding the nature of clowns in wayang, we can see how "the times of comedy" (zaman dagelan) are also the times of bringing in the present, the modern, and the foreign, or as a writer quoted earlier in this essay put it, "zaman campursari," which I have translated as "the times of mixedness."

172 R. M. Sayid, “Hubungan antara wayang dan Penanggap," p. 6.

173 Similarly, Claire Holt writes in a footnote: "Reportedly in recent years (1963-65) there has been a trend toward an increasing share of farce and satire in both wayang kulit and wayang wong-a sign of the times?" Claire Holt, Art in Indonesia: Continuities and Change (Ithaca: Cornell University Press, 1967), p. 148. See also my comments on the parallels between mid-1990s Golkar's and 1960s PKI's wayangs in the next part. 
It is interesting that the clowns, who are traditionally crazy and funny and bring in the modern and the strange, are also most of the present, are so sympathetic to and loved by wayang spectators, by common Javanese people, and are often said, in a complex way, to represent the common Javanese themselves. This may suggest something about how the present world is seen from the perspective of wayang: the present world, and the Javanese who watch wayang, and who find themselves to be like the clowns, who speak the same language, are, wayang says, somewhat funny and crazy, and also somewhat foreign to wayang - to wayang, which is the most Javanese thing in Java (or at least that is what many people who watch wayang claim). Thus, wayang says, the Javanese are to some extent foreign to themselves. That the clowns are becoming more important, that all the characters are becoming crazy clowns, and that the performances are crazier than ever, suggests that wayang now finds the world around itself, and the people who live in it, even crazier and funnier than ever. ${ }^{174}$

Having seen that the modern and the international is identified with the funny and the crazy in wayang, and that it is brought in by the clowns, we also learn what wayang says about the "global" or the "international," that is, we learn a Javanese view of the Javanese place in the international world. The international, the global, is both foreign and crazy, and it is one of the most fascinating and appealing things for the Javanese, and something that is now at the center of wayang, of what many Javanese say is the most Javanese representation of the Javanese world. In other words, as we look at the recent developments in wayang, we can see what I think is a very lively picture of the present world and cultural interaction. It is not simply a matter of power struggles, though those are also involved; one sees that for the Javanese to be international means to be crazy and funny, like the wayang clowns, and out-of-tune, like most campursari music; but "going international" has also a great appeal, it fascinates, and this crazy and funny international is at the center of the present Javanese world.

This case of insanity is only a chapter, or a footnote, in the development of wayang performances. Again, the clowns, and with them the present and the foreign, and the crazy and the funny, have been a part of wayang for a long time, and Semar has farted since times immemorial. Thus, while I see the developments today as to some extent a unique case, and I have tried to bring out the uniqueness of the contemporary scene, the development nonetheless constitute merely one chapter in the history of wayang, $a$. chapter from the history of Indonesia. This assimilation of and appreciation for the foreign is, many scholars argue, one of the things that makes the study of Indonesia so interesting and relevant for the present. This case also figures as one moment in the

174 Speaight writes about medieval religious drama in England: "It is interesting to see the intrusion of comic local character into this early religious spectacle; comic local characters were to continue to intrude into every kind of spectacle on the puppet stage for the next four hundred years, and they had probably been doing the same thing for at least two thousand years previously." (George Speaight, The History of the English Puppet Theater, 2nd ed. [1990], p. 34.) Here, too, the "local," when it "intrudes" into a representation of a distant world of mythical or religious narrative, is comic. Here we have an interesting parallel with the Javanese clowns who are comic for very similar reasons, and this parallel may suggest a more universal aspect or manifestation of the comic: the contemporary local "me" feeling "funny" (strange, comic) in the midst of myths that are meant to be taken seriously. Specifically in the puppet theater, this could be understood in the context of the inherent strangeness of puppets that makes them especially suited for representing myths and dreams (which is discussed in Mrázek, "Phenomenology of a Puppet Theater," Chapter One): in this perspective, the comic rests in the strangeness of recognizing the "present local myself" in the dream-like being of a puppet, a "dead" thing that appears alive (hence its strangeness). 
human experience of interaction among different people and different cultures. It illustrates how a people sees itself and others in their encounters and in their "going international" or "going global." This "going international" is something to be taken seriously and reflected upon, but, at the same time, as we can see on this case, "going international" often results in all kinds of funny, bizarre, and embarrassing situations. There is something very bizarre about a Czech person teaching -in broken Englishabout Javanese wayang at an American university; in wayang, too, the international and the foreign, crazy though it may be, is a part of its world, and a clown, or the puppet of a crazy foreigner, has its role to play among the mythical princes, knights, and monsters ... who may be slowly turning into clowns.

Having considered innovations in selected aspects of the performance, we have been led to realize a new kind of wholeness of the modern performance. The clown scenes are ruptures or "breaks" in the performance time, and within the clown scenes the songs, jokes, and attractions are also separate and never necessarily connected together, only freely juxtaposed in the performance. Following this line of thought, we begin to see that the clown scenes, though still breaks, are more and more like the rest of the performance, because the rest of the performance is more like them; that is, the whole performance is less "broken up" by the clown scenes now because the clown scenes are only special times in a performance that is increasingly characterized by fragmentation. Thus, the performance has a unity in the sense that it is all characterized, to different extents, by diversity, by presenting separate attractions that are not meant to be connected together. Traditionally, too, the different components of the performance can be enjoyed, to some extent, also separately (as music, as battlescenes, as dialogues, and so forth), but they show themselves more ready to come together, to be related together, so that they enhance the meaning or dramatic impact of each other and the whole. For instance, dramatic music tends to support the dramatic situation, rather than being only enjoyed for its own sake, like a song in the clown scene. The development is a matter of a more or less subtle shift in emphasis, a tendency: what is presented less, and less often, asks the viewer to connect the parts together. The whole is built up and holds together somewhat differently, more loosely, than in more traditional performances-rather like a clown scene, or like a musical piece played simultaneously in-juxtaposing-Javanese and Western tunings, without tuning-relating-closely one to the other, and without making any coincidental relations significant (traditionally, coincidences, too, are significant). Yet as the appeal of an inappropriate joke often lies in part in its negation of propriety (the forbiddenfruit factor), or as the foreign in wayang is funny or otherwise appealing in part because it is perceived in the way it conflicts with something else in the character of wayang, so the appeal of this loosening or break-down of the relations in wayang performance, for those who find it appealing, derives in part from its negative relation to another persisting manner of being of the wayang performance-which means that the new character of the whole, as described in this paragraph, is only a part of the story.

The continuation of this essay will be published in the next issue of Indonesia. 